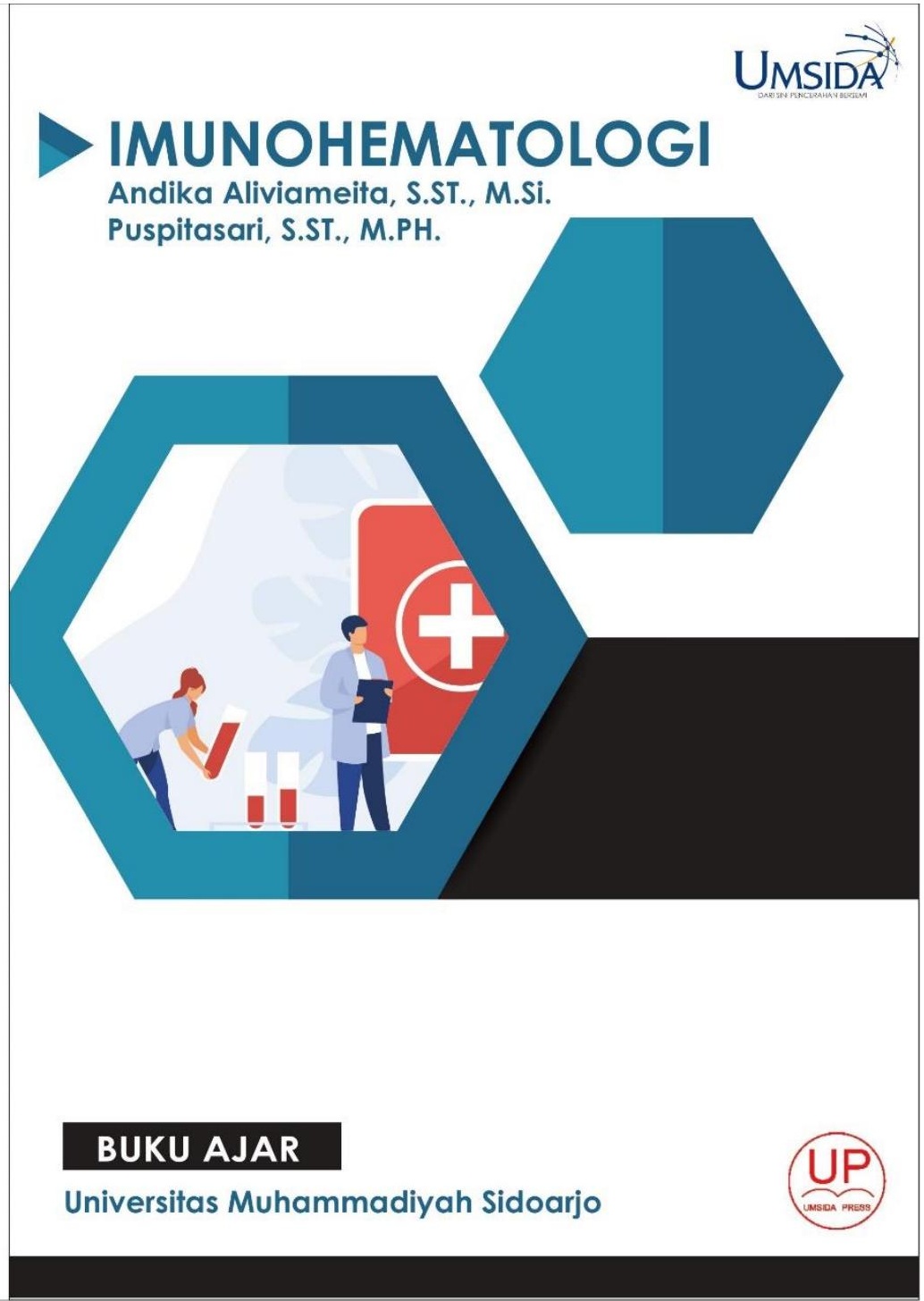




\title{
BUKU AJAR MATA KULIAH IMUNOHEMATOLOGI
}

\author{
Oleh \\ Andika Aliviameita, S.ST., M.Si. \\ Puspitasari, S.ST., MPH.
}

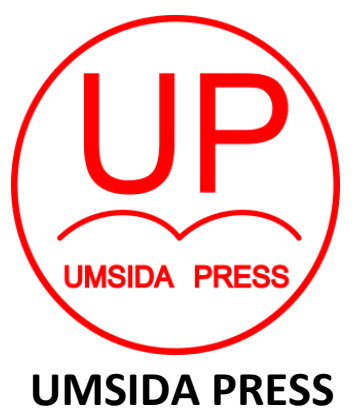

Sidoarjo

PROGRAM STUDI TEKNOLOGI LABORATORIUM MEDIS

FAKULTAS ILMU KESEHATAN

UNIVERSITAS MUHAMMADIYAH SIDOARJO

2020 


\section{BUKU AJAR}

\section{IMUNOHEMATOLOGI}

\section{Penulis :}

Andika Aliviameita, S.ST., M.Si.

Puspitasari, S.ST., MPH.

\section{ISBN :}

978-623-6833-44-5

\section{Editor :}

Miftahul Mushlih, M.Sc.

Design Sampul dan Tata Letak :

Mochammad Nashrullah, S.Pd

Amy Yoga Prajati, S.Kom.

\section{Penerbit :}

UMSIDA Press

Anggota IKAPI No. 218/Anggota Luar Biasa/JTI/2019

Anggota APPTI No. 0020181092017

\section{Redaksi :}

Universitas Muhammadiyah Sidoarjo

Jl. Mojopahit No 666B

Sidoarjo, Jawa TImur

Cetakan pertama, November 2020

(C) Hak cipta dilindungi undang-undang

Dilarang memperbanyak karya tulis ini dengan sengaja, tanpa ijin tertulis dari penerbit. 


\section{KATA PENGANTAR}

Puji syukur kehadirat Tuhan Yang Maha Esa atas limpahan hidayahnya sehingga penulis dapat menyusun "Buku Ajar Imunohematologi" dengan baik. Buku ini berisi tentang antigen dan antibodi, sistem golongan darah, sistem administrasi donor darah, teknologi pengolahan darah, dan reaksi transfusi darah.

Buku ini dapat disusun dengan baik berkat kerjasama dan bantuan dari berbagai pihak. Oleh karena itu saya menyampaikan banyak terima kasih kepada segenap pihak yang telah berkontribusi secara maksimal dalam penyelesaian buku ini.

Penulis menyadari bahwa masih banyak kekurangan dalam penulisan buku, baik dari segi tata bahasa, susunan kalimat maupun isi. Oleh karena itu penulis menerima segala kritik dan saran yang membangun dari para pembaca.

Akhir kata semoga buku ini dapat menambah khazanah ilmu pengetahuan dan memberikan manfaat khususnya bagi prodi D-IV Teknologi Laboratorium Medis Fakultas Ilmu Kesehatan Universitas Muhammadiyah Sidoarjo.

Sidoarjo, September 2020

Tim Penulis 


\section{DAFTAR ISI}

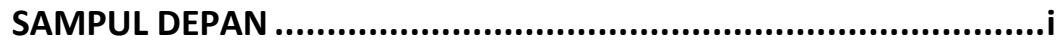

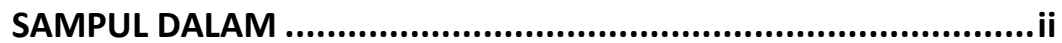

KATA PENGANTAR ............................................................ ii

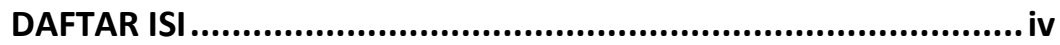

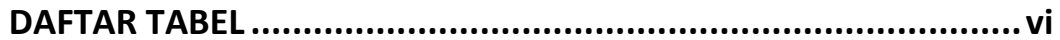

DAFTAR GAMBAR .......................................................... vii

DAFTAR SINGKATAN DAN ISTILAH ..................................... viii

BAB 1. PENGANTAR IMUNOLOGI ................................................. 1

1.1 Definisi Imunohematologi ............................................. 1

1.2 Sistem Imunitas Tubuh ................................................... 2

1.3 Antigen (Imunogen) ........................................................ 5

1.4 Antibodi (Imunoglobulin) ................................................ 8

1.5 Mekanisme Respon Imun ............................................. 15

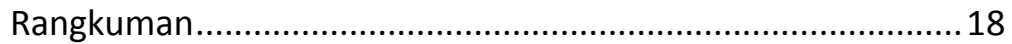

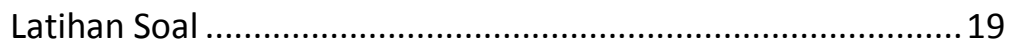

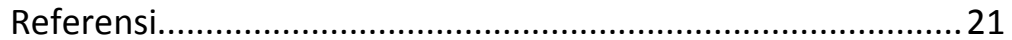

BAB 2. SISTEM GOLONGAN DARAH ......................................... 23

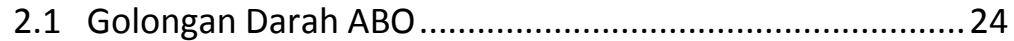

2.2 Golongan Darah Rhesus.............................................. 43

2.3 Golongan Darah Lewis ..................................................52

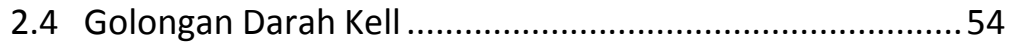

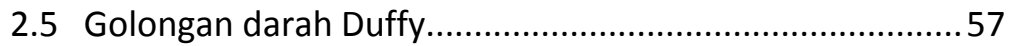

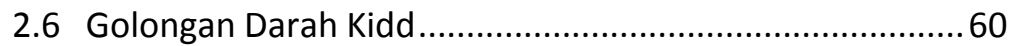

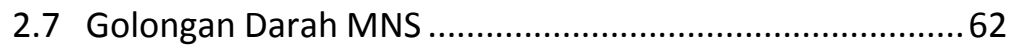

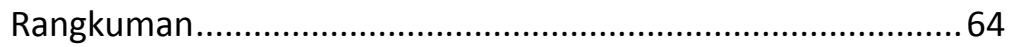

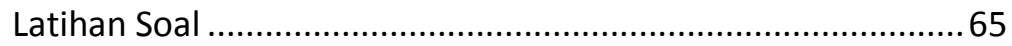

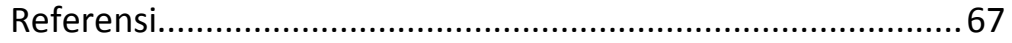


3.1 Komponen Darah........................................................69

3.2 Kriteria Donor dalam Pengambilan Darah........................ 73

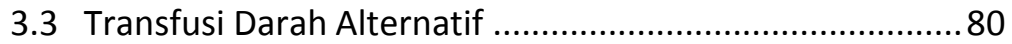

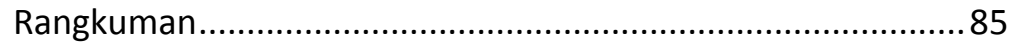

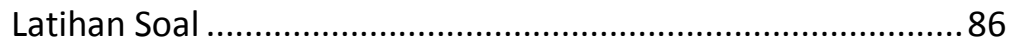

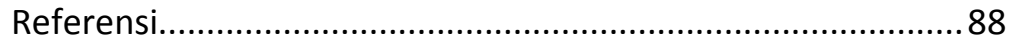

BAB 4. TEKNOLOGI PENGOLAHAN DARAH ................................90

4.1 Preparasi Donor Darah ...................................................91

4.2 Komponen Donor darah ...............................................94

4.3 Penyimpanan Komponen Darah..................................... 105

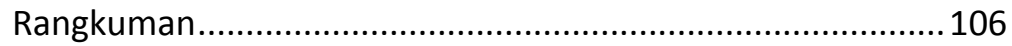

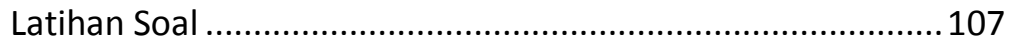

Referensi....................................................................... 108

BAB 5. REAKSI TRANSFUSI DARAH ...................................... 111

5.1 Definisi dan Penyebab Reaksi Transfusi ........................111

5.2 Reaksi Transfusi Akut .................................................... 112

5.3 Reaksi Transfusi Tertunda ...................................... 114

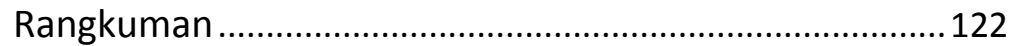

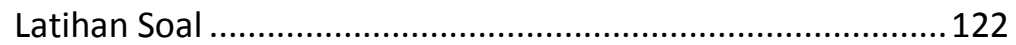

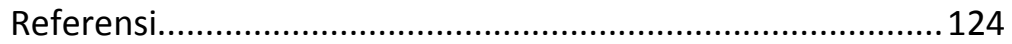




\section{DAFTAR TABEL}

Tabel 1.1 Imunogenisitas Berbagai Antigen ................................... 5

Tabel 1.2 Ciri-ciri Jenis Imunoglobulin ............................................ 14

Tabel 2.1.a Sistem Golongan Darah Utama...................................25

Tabel 2.1.b Sistem Golongan Darah Lain .....................................26

Tabel 2.2 Berbagai jenis dan Fungsi Sistem Golongan Darah ........27

Tabel 2.3 Perbedaan Golongan darah O dan Oh...........................32

Tabel 2.4 Genotip dan Fenotip Golongan Darah ABO .................... 32

Tabel 2.5 Tabel Pewarisan Golongan Darah.................................33

Tabel 2.6 Enzim Transferase untuk Produksi Antigen ABH ............33

Tabel 2.7 Antigen dan Antibodi Golongan Darah ABO..................37

Tabel 2.8 Konversi antara Nomenklatur Fisher-Race \& Weiner.....47

Tabel 2.9 Ringkasan Nomenklatur Sistem Golongan Darah Rh......48

Tabel 2.10 Karakteristik Antibodi Sistem Golongan Darah Rh .......51

Tabel 2.11 Frekuensi Antigen Sistem Golongan Darah Lewis ........53

Tabel 2.12 Gen Lewis, Sekretor, dan H dan Produknya .................53

Tabel 2.13 Antigen Antitesis Sistem Golongan Darah Kell ............. 55

Tabel 2.14 Persentase Frekuensi Fenotip Antigen Duffy ..............5 59

Tabel 2.15. Fenotip dan Frekuensi Golongan Darah Kidd ..............61

Tabel 2.16 Frekuensi Antigen Golongan Darah MNS Dewasa........63

Tabel 2.17 Karakteristik Antibodi MN ........................................63

Tabel 3.1 Masa Penangguhan Sementara Administrasi Vaksin ..... 77

Tabel 3.2 Masa Penangguhan Donor Darah Selama 12 Bulan.78

Tabel 3.3 Reaksi Negatif Donor dan Penanganannya ....................79

Tabel 4.1 Berbagai Tipe Kantong Darah dan Komponennya..........93

Tabel 4.2 Berbagai Antikoagulan dalam kantong Darah ................94

Tabel 4.3 Kriteria Penyimpanan Berbagai Komponen Darah.......105

Tabel 5.1 Jenis Reaksi Transfusi Dimediasi oleh Imun\&Non-Imun 


\section{DAFTAR GAMBAR}

Gambar 1.1 Mekanisme Fagositosis pada Mikroba ....................... 6

Gambar 1.2 Antigen Pada Eritrosit................................................. 8

Gambar 1.3 Epitop pada Eritrosit................................................ 9

Gambar 1.4 Struktur Sederhana Jenis-jenis Antibodi ...................10

Gambar 1.5 Struktur Imunoglobulin G .......................................11

Gambar 2.1 Perbedaan Struktural Umum pada Rantai

Oligosakarida yang Berfungsi sebagai Prekursor untuk Antigen $\mathrm{ABH}$

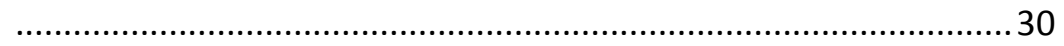

Gambar 3.1 Alat Therapeutic Apheresis ....................................84

Gambar 4.1 Kantong darah ...................................................... 92

Gambar 4.2 Persiapan Komponen dari Satu Unit Whole Blood .....96 


\section{DAFTAR SINGKATAN DAN ISTILAH}

DHTR : Delayed Hemolytic Transfusion Reaction

DSTR : Delayed Serological Transfusion Reaction

FDA : Food and Drug Administration

FFP : Fresh Frozen Plasma

GMP : Good Manufacturing Practices

FNHTR : Febrile Non Hemolytic Transfusion Reaction

HDFN : Hemolytic Disease of the Fetus and Newborn

HDN : Hemolytic Disease of the

HLA : Human Leucocyte Antigen

HPA : Human Platelet Antigen

HTR : Hemolitic Transfusion Reaction

IHTR : Immediate Hemolytic Transfusion Reaction

ISBT : International Society of Blood Transfusion

PC : Platelet Concentrates

PTP : Post Transfusion Purpura

TA-GVHD : Transfusion-associated graft-versus-host disease

TACO : Transfusion-Associated Circulatory Overload

TRALI : :Transfusion-Related Acute Lung Injury

TRBC :Transfusion Related Bacteria Contamination

VWF : Von Willebrand Factor 


\section{BATANG TUBUH DAN \\ SUB-CAPAIAN PEMBELAJARAN MATA KULIAH \\ BAB Sub - Capaian Pembelajaran Mata Kuliah}

BAB 1.

PENGANTAR

IMUNOLOGI

BAB 2.

SISTEM

GOLONGAN

DARAH

- Mampu memahami tentang sistem imunitas tubuh.

- Mampu memahami perbedaan sistem imun spesifik dan sistem imun non spesifik, serta respon imun tubuh.

- Mampu menjelaskan tentang perbedaan antigen dan antibodi, HLA dan HPA, dan jenis immunoglobulin.

- Mampu menjelaskan mekanisme respon imun.

- Mampu memahami mengenai sistem golongan darah beserta aspek klinisnya

- Mampu menjelaskan tentang sejarah, persebaran, antigen dan antibodi golongan darah $\mathrm{ABO}$, Fenotip Bombay, dan status sekretor.

- Mampu menjelaskan tentang sejarah, antigen, dan antibodi golongan darah Rhesus

- Mampu memahami antigen dan antibodi golongan darah Lewis, Kell, Duffy, Kidd, MNS.

BAB 3.

- Mampu memahami tentang jenis-jenis

SISTEM komponen darah beserta dengan ADMINISTRASI fungsinya. 
DONOR

DARAH

BAB 4.

TEKNOLOGI

PENGOLAHAN

DARAH

TRANSFUSI

BAB 5. REAKSI

TRANSFUSI

DARAH
- Mampu menjelaskan tentang persyaratan atau kriteria donor dalam pengambilan darah

- Mampu memahami mengenai macam transfusi darah alternatif

- Mampu memahami tentang preparasi sebelum melakukan pengambilan darah pada pendonor.

- Mampu memahami tentang macammacam komponen darah yang dapat di donorkan

- mampu menjelaskan cara penyimpanan komponen darah

- Mampu memahami tentang penyebab terjadinya reaksi transfusi darah.

- mampu memahami perbedaan reaksi transfusi akut dan tertunda.

- Mampu memahami berbagai jenis reaksi transfusi yang di mediasi oleh sistem imun dan non-imun. 


\section{BAB 1}

\section{PENGANTAR IMUNOLOGI}

\section{Sub - Capaian Pembelajaran Mata Kuliah :}

- Mampu memahami tentang sistem imunitas tubuh.

- Mampu memahami perbedaan sistem imun spesifik dan sistem imun non spesifik, serta respon imun tubuh.

- Mampu menjelaskan tentang perbedaan antigen dan antibodi, HLA dan HPA, dan jenis immunoglobulin.

- Mampu menjelaskan mengenai mekanisme respon imun.

\subsection{Definisi Imunohematologi}

Imunohematologi terdiri dari dua kata, yaitu "immune" yang berhubungan dengan respon imun, dan "hematologi" yaitu ilmu yang mempelajari tentang darah. Pada buku ini akan membahas tentang imunologi dasar, penerapan konsep imunologi pada pemeriksaan laboratorium dan transfusi darah, serta komponen darah. Topik yang akan dibahas antara lain: sistem antigen golongan darah dan antibodi yang terkait, pemeriksaan pra-transfusi, donor komponen darah, prinsip pengumpulan sampel darah, resipien (penerima komponen darah), kondisi klinis yang membutuhkan transfusi darah, serta efek samping pasca transfusi darah.

Sistem imun merupakan sistem yang paling beragam pada tubuh manusia dan berfungsi untuk perlindungan organisme host. Mekanisme pertahanan spesifik dimulai dari permukaan tubuh eksternal, kemudian meluas hingga mencakup jaringan, organ, dan pertahanan seluler. Sistem imun berperan membedakan self dari non-self dan menghancurkan organism berbahaya. Organisme non- 
self dapat berupa uniseluler sampai multiseluler, termasuk bakteri, virus, jamur, dan parasit.

Sistem imun tubuh tidak bersifat otonom, melainkan bekerjasama dengan sistem lain di dalam tubuh. Sistem yang berinteraksi dengan sistem imun yaitu sistem hematopoietik, pencernaan, pernafasan, dan saraf. Tanpa adanya sistem imun maka sistem tubuh lain beresiko diserang oleh organisme patogen. Oleh karena itu, sistem imun mempunyai peran vital pada tubuh manusia.

\subsection{SISTEM IMUNITAS TUBUH}

Imunologi merupakan ilmu yang mempelajari tentang imunitas atau kekebalan akibat adanya rangsangan molekul atau substansi asing dari luar maupun dari dalam tubuh, baik yang bersifat infeksius maupun non infeksius. Substansi yang dapat menimbulkan respon imun disebut antigen. Tubuh memiliki sistem pelacakan dan penjagaan terhadap substansi atau molekul asing yang disebut sistem imun. Sistem imun akan memberikan respon dan melindungi tubuh terhadap zat asing, seperti mikroorganisme penyebab penyakit patogen (virus, bakteri, parasit, jamur), sel tumor, sel/ jaringan alogen, bahan atau zat yang bersifat antigen (alergen). Terdapat dua macam sistem imun, yaitu sistem imun non spesifik (innate immunity) dan sistem imun spesifik (adaptive immunity). Kedua sistem ini berperan dalam melindungi tubuh dan mengeliminasi agen penyakit.

\section{A. Sistem Imun Non Spesifik}

Sistem imun non spesifik adalah pertahanan tubuh yang bersifat tidak spesifik dan berfungsi sebagai barier terdepan pada saat terjadinya infeksi penyakit, sehingga sering disebut natural 
atau native immunity. Komponen utama sistem imun non spesifik (bawaan) yaitu pertahanan fisik dan kimiawi seperti epitel dan substansi antimikroba yang diproduksi oleh epitel, berbagai protein dalam darah seperti komponen sistem komplemen, mediator inflamasi, sitokin, sel fagosit (sel-sel polimorfonuklear, makrofag, Natural Killer). Usaha tubuh dalam mempertahankan diri terhadap masuknya antigen bakteri adalah dengan cara menghancurkan bakteri yang masuk secara non spesifik dengan proses fagositosis (Gambar 1.1), tanpa memperhatikan perbedaan kecil pada antigen tersebut. Proses fagositosis melibatkan sel makrofag,neutrofil, dan monosit.

\section{B. Sistem Imun Spesifik}

Sistem imun spesifik ialah sistem pertahanan tubuh kedua ketika sistem imun non spesifik tidak dapat mengeliminasi agen penyakit. Hal ini terjadi apabila fagosit tidak mengenali agen infeksius karena hanya sedikit reseptor yang cocok untuk agen infeksius atau agen tidak bertindak sebagai faktor antigen terlarut (soluble antigen) yang aktif. Sehingga diperlukan molekul spesifik yang akan berikatan langsung dengan agen infeksius yang dikenali oleh antibodi untuk selanjutnya terjadi fagositosis. Sistem imun spesifik mempunyai ciri utama, antara lain: (a). Spesifisitas. Respon yang timbul terhadap antigen pada komponen struktural kompleks protein atau polisakarida yang berbeda, tidaklah sama. Bagian dari antigen yang dikenali oleh limfosit disebut determinan antigen (epitop); (2). Diversitas. Limfosit memiliki reseptor terhadap antigen dengan bentuk struktur yang berbeda; (3). Memori. Limfosit mempunyai kemampuan dalam mengingat antigen yang pernah masuk ke dalam tubuh dan memberikan respon yang lebih efektif pada paparan berikutnya; (4). Spesialisasi. Sistem imun memberikan 
respon dan dengan cara yang berbeda terhadap berbagai jenis mikroba; (5). Membatasi diri (self limition). Setelah rangsangan antigen, respon imun normal akan mereda dalam waktu tertentu. Ini dikarenakan antigen yang masuk telah disingkirkan dan adanya regulasi umpan balik yang menyebabkan terhentinya respon imun tersebut; (6) Membedakan self dan non-self. Pada sistem imun normal akan menunjukkan toleransi terhadap antigen tubuh sendiri.

\section{Respon Imun Tubuh}

Respon imun tubuh dipengaruhi oleh kemampuan sistem imun untuk mengenali molekul asing (antigen) yang terdapat pada patogen potensial dan menstimulasi reaksi yang tepat untuk menyingkirkan sumber antigen bersangkutan. Proses pengenalan antigen dilakukan oleh limfosit yang merupakan unsur utama sistem imun, kemudian diikuti oleh fase efektor yang melibatkan berbagai jenis sel. Limfosit memiliki kemampuan diversifikasi karena harus mengenal semua antigen pada patogen potensial dan d iwaktu bersamaan harus mengabaikan molekul-molekul jaringan tubuh sendiri (toleransi).

Kemampuan diversifikasi dimiliki oleh komponen-komponen sistem imun yang terdapat dalam jaringan limforetikuler yang terletak diseluruh tubuh, yaitu: sumsum tulang, kelenjar limfe, limpa, kelenjar getah bening, jantung, timus, sistem saluran nafas, usus halus, usus besar, dan sebagainya. Sel-sel yang terdapat pada jaringan ini berasal dari sel induk (stem cell) dalam sumsum tulang yang berdiferensiasi menjadi berbagai jenis sel, kemudian beredar dalam tubuh melalui darah, getah bening, dan jaringan limfoid serta dapat menunjukkan respon terhadap suatu stimulasi sesuai dengan sifat dan fungsinya masing-masing. Stimulasi terhadap sel-sel 
tersebut terjadi apabila adanya suatu zat yang oleh sel atau jaringan tubuh dianggap asing. Sistem imun mampu membedakan zat asing (non-self) dari zat yang berasal dari tubuh sendiri (self). Pada beberapa keadaan patologik, sistem imun tidak mampu membedakan self dari non-self sehingga sel-sel dalam sistem imun membentuk zat anti terhadap jaringan tubuhnya sendiri. Zat anti ini dinamakan autoantibodi.

Tabel 1.1 Imunogenisitas Berbagai Antigen

\begin{tabular}{ll}
\hline Antigen & Imunogenisitas \\
\hline Protein & +++ \\
Karbohidrat & ++ \\
Lemak & $+/-$ \\
Asam nukleat & - \\
(Olson \& Nardin, 2016) &
\end{tabular}

\subsection{ANTIGEN (IMUNOGEN)}

Antigen merupakan substansi atau molekul yang dapat merangsang pembentukan antibodi. Namun, kini antigen didefinisikan sebagai substansi yang mampu bereaksi dengan antibodi yang diproduksi oleh sel $B$ atas rangsangan imunogen, tanpa mempertimbangkan apakah antigen bersifat imunogenik. Ini artinya semua imunogen adalah antigen, namun tidak semua antigen adalah imunogen. Imunogen memiliki kemampuan dalam menginduksi respon imun dengan bantuan sel T. Tidak semua bagian dari antigen dapat berinteraksi dengan molekul sistem imun. Bagian dari antigen yang dapat berikatan dengan antibodi atau dengan reseptor spesifik pada limfosit $\mathrm{T}$ dsebut epitop. Ini menandakan bahwa antigen mempunyai beberapa epitop. 
Sedangkan hapten merupakan molekul organik kecil yang mampu mengikat bagian reseptor antigen.

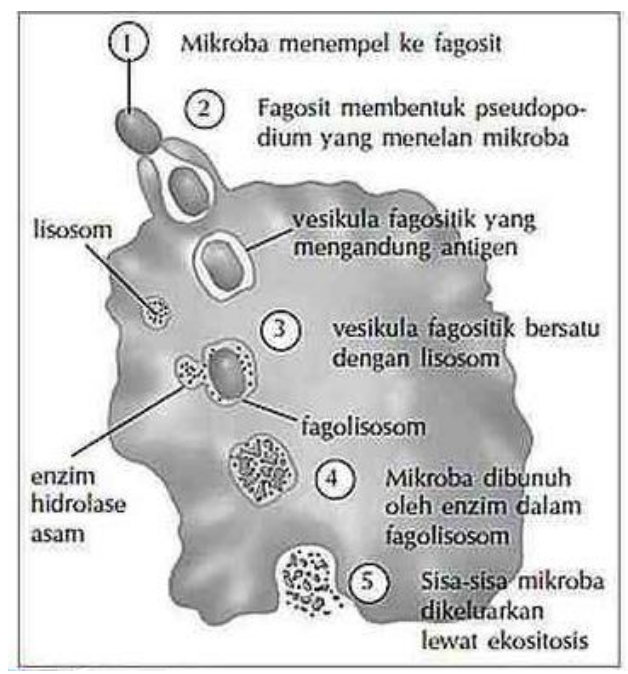

Gambar 1.1 Mekanisme Fagositosis pada Mikroba (Brainly.co.id)

Suatu zat atau substansi bersifat imunogenitas apabila memiliki sifat, antara lain: (1). Keasingan; (2) ukuran molekul; (3) kompleksitas struktur kimia; (4) kemudahan untuk mengenali, mengambil, dan mendegradasi oleh sel penyaji antigen; (5) secara tidak langsung, metode pengenalan antigen; (6) kehadiran zat kimia tertentu yang dapat bekerja sebagai adjuvan imun.

Pada transfusi darah, imunohematologi yang diaplikasikan mengutamakan reaksi antara antigen pada eritrosit dengan antibodi pada serum/ plasma. Eritrosit memiliki banyak antigen pada permukaan membrannya, inilah yang digunakan dalam penentuan golongan darah (Gambar 1.2). Ada banyak golongan darah selain $A B O$, seperti Rhesus, MN, Lewis, Kell dan Duffy, dan lain-lain. 
Permukaan membran eritrosit memiliki banyak epitop yang menentukan spesifisitas dan kekuatan reaksi antigen dan antibodi (Gambar 1.3). Epitop umumnya berukuran kecil, yaitu \pm 10.000 Dalton. Substansi atau zat dengan berat molekul $<10.000$ Dalton umumnya tidak bersifat imunogenik namun bila diikat pada protein pembawa yang berukuran cukup besar, maka dapat membentuk kompleks yang dapat menstimulasi respon imun untuk memproduksi antibodi terhadap molekul tersebut. Substansi ini dinamakan hapten. Hapten bentuk kompleksnya dapat bereaksi dengan antibodi meskipun ia tidak bersifat imunogenik.

\section{A. Human Leucocyte Antigen (HLA)}

HLA juga dikenal dengan sistem Major Histocompatibility Complex (MHC), dan disekresikan di membran sel berinti, antara lain limfosit, granulosit, monosit, trombosit, dan organ-organ lainnya. HLA terdiri dari dua jenis, yaitu HLA kelas 1 berada di sel darah berinti di peredaran darah tepi dan trombosit. HLA kelas I ada tiga jenis, yaitu: HLA-A, HLA-B, dan HLA-C. Sedangkan HLA II terletak di limfosit dan monosit. HLA II meliputi HLA-DR, HLA-DQ, dan HLADP. HLA bersifat sangat imunogenik. Antibodi terhadap HLA dapat terbentuk pada seseorang pada masa transfusi, hamil, dan transplantasi organ. Pasien yang akan melakukan transplantasi organ sebelumnya harus dilakukan pemeriksaan HLA typing untuk menghindari terjadinya proses penolakan organ di tubuh pasien. Pada proses transfusi darah, komponen darah yang akan ditransfusikan terlebih dahulu dihilangkan leukositnya (leucopoor) guna menghindari ketidakcocokan HLA antara pendonor dan resipien. 


\section{B. Human Platelet Antigen (HPA)}

HPA merupakan antigen yang terdapat pada glikoprotein membran trombosit. Sampai saat ini diketahui ada 33 jenis HPA yang terdapat pada trombosit. Apabila terjadi ketidakcocokan HPA akan menyebabkan terbentuknya antibodi terhadap HPA, yang mengakibatkan trombositopenia. Pada reaksi transfusi, anti HPA dapat menyebabkan kegagalan meningkatnya jumlah trombosit pasca transfusi darah, perdarahan, dan timbulnya bintik atau bercak merah (purpura).

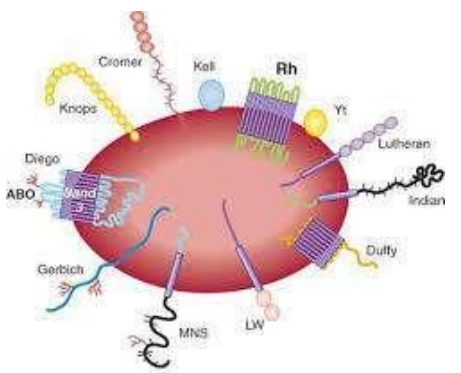

Gambar 1.2 Antigen Pada Eritrosit (Maharani\& Noviar, 2018)

\subsection{ANTIBODI (IMUNOGLOBULIN)}

Antibodi atau imunoglobulin dihasilkan oleh sistem imun dan penting untuk pencegahan dan perlawanan infeksi oleh substansi asing seperti bakteri, virus, parasit, dan zat patogen lainnya. Antibodi merupakan glikoprotein yang berikatan khusus dengan substansi atau molekul asing yang disebut antigen. Struktur dasar antibodi terdiri dari dua rantai berat (heavy chain) dan 2 rantai ringan (light chain) yang identik serta dihubungkan bersama oleh ikatan disulfide (S-S). Molekul ini dapat dipecah menjadi tiga fragmen oleh enzim proteolitik, yaitu2 fragmen yang mempunyai susunan sama terdiri atas rantai berat dan rantai ringan, dinamakan fragmen Fab yang dibentuk oleh domain terminal-N. Dan 1 fragmen 
yang terdiri dari rantai berat saja, dinamakan fragmen Fc yang dibentuk oleh domain terminal-C. Fragmen Fab dengan antigen binding site berfungsi untuk mengikat antigen. Sedangkan fragmen Fc tidak memiliki kemampuan dalam mengikat antigen tetapi dapat bersifat sebagai determinan antigen, serta berfungsi sebagai efektor sekunder yang menentukan sifat biologis dari munoglobulin tersebut.

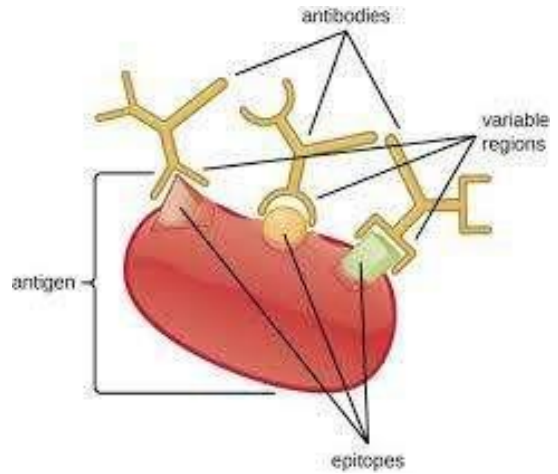

Gambar 1.3 Epitop pada Eritrosit (Maharani\& Noviar, 2018)

Ciri khusus dari molekul antibodi yaitu terdapat pada perbandingan urutan asam amino dari berbagai molekul imunoglobulin. Ini menunjukkan bahwa imunoglobulin terdiri dari berbagai copi folding unit sekitar 100 asam amino, yang masingmasing membentuk struktur serupa yang independen yang disebut lipatan imunoglobulin (immunoglobulin fold). Domain N-terminal dari setiap polipeptida (rantai berat dan ringan) sangat bervariasi, sedangkan domain lainnya memiliki urutan konstan. Pembentuk domain disebut wilayah variabel (V region) sedangkan yang terakhir adalah wilayah konstan (C region). Selain itu, perbandingan urutan wilayah $\mathrm{V}$ menunjukkan bahwa variabilitas tidak terdistribusi secara merata namun terkonsentrasi dalam tiga wilayah, yang disebut 
daerah hypervariable. Struktur jenis-jenis antibodi ada pada Gambar 1.4 dan 1.5.

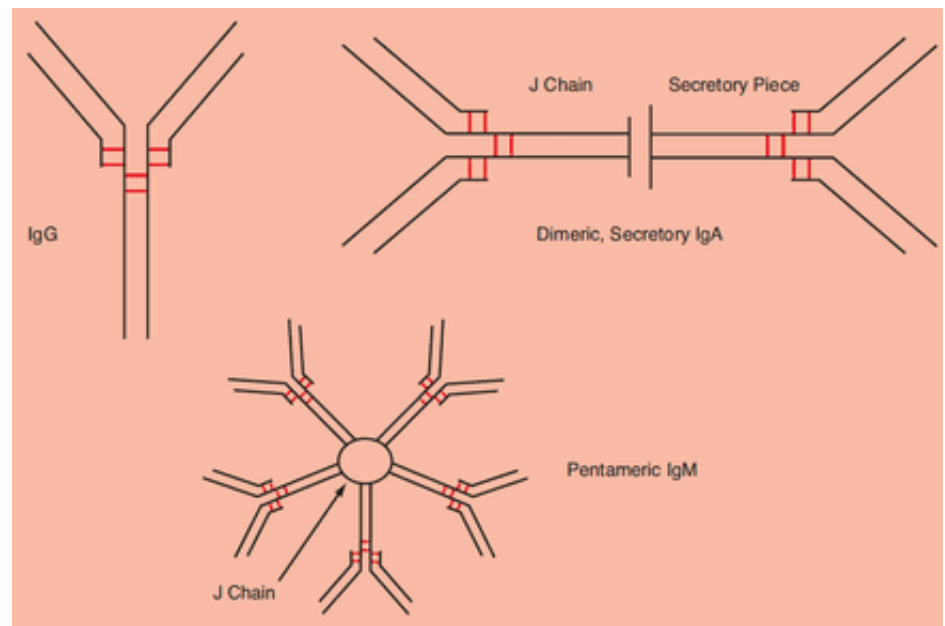

Gambar 1.4 Struktur Sederhana Jenis-jenis Antibodi (Quinley, 2011)

\section{$>$ Klasifikasi Imunoglobulin}

Ada lima jenis imunoglobulin (IgG, IgA, IgM, IgD, dan IgE) yang berbeda dalam urutan asam amino dan jumlah domain di area konstan pada rantai berat. Ada dua isotype rantai ringan yang berbeda ( $\lambda$ dan $k$ ). IgG merupakan jenis utama imunoglobulin dalam serum normal. Kelima jenis imunoglobulin ini dinamakan berdasarkan rantai berat penyusunnya. Imunoglobulin $G$ memiliki rantai berat $\gamma$, imunoglobulin $M$ memiliki rantai berat $\mu$, imunoglobulin A memiliki rantai berat $\alpha$, imunoglobulin $D$ memiliki rantai berat $\delta$, imunoglobulin $E$ memiliki rantai berat $\varepsilon$. Di bidang transfusi darah banyak melibatkan IgG dan IgM karena berhubungan dengan pemeriksaan pre transfusi, yaitu pemeriksaan sebelum dilakukan 
transfusi darah. Ciri dari jenis-jenis Imunoglobulin ada pada Tabel 1.2. Berikut ini merupakan jenis-jenis imunoglobulin, yaitu:

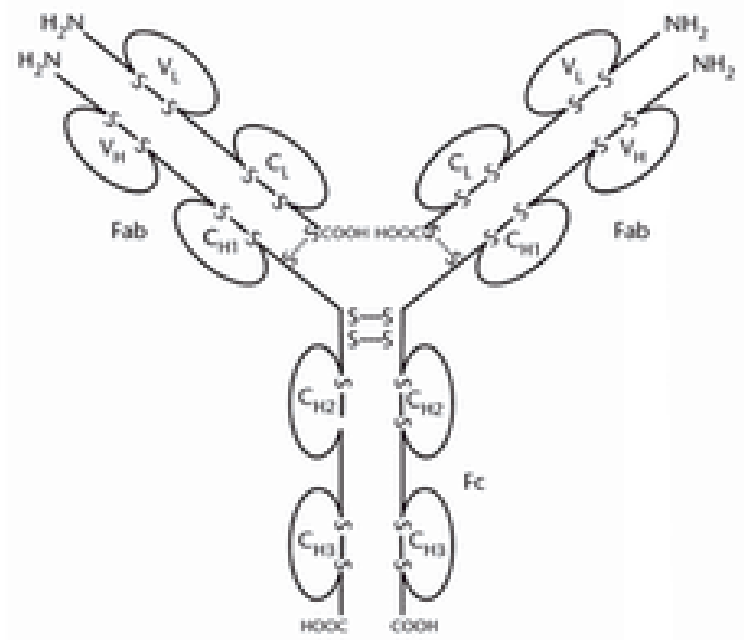

Gambar 1.5 Struktur Imunoglobulin G (Kumagai \& Tsumoto, 2014)

\section{(1). Imunoglobulin G}

Sebanyak $75 \%$ dalam serum manusia dewasa normal mengandung Imunoglobulin G. Struktur IgG berbentuk monomer, dan merupakan imunoglobulin utama yang dibentuk atas rangsangan antigen yang masuk ke dalam tubuh. IgG dapat menembus plasenta dan masuk ke dalam sistem peredaran darah janin sehingga IgG dari ibu dapat melindungi bayi dari infeksi. IgG paling mudah berdifusi ke dalam jaringan ekstravaskular dan melakukan aktivitas sebagai antibodi di jaringan. IgG juga dapat melapisi mikroorganisme sehingga mudah difagositosis, serta dapat menetralisir toksin dan virus. IgG mempunyai half life selama 23 hari di dalam darah. 


\section{(2). Imunoglobulin M}

Molekul imunoglobulin $M$ berbentuk pentamer dan berukuran paling besar. IgM banyak terdapat di intravaskular dan merupakan $10 \%$ dari total imunoglobulin pada serum. IgM adalah imunoglobulin pertama yang dibentuk pada saat antigen masuk ke dalam tubuh, tetapi memiliki respon yang pendek (hanya beberapa hari dan kemudian kembali menurun). IgM tidak mampu menembus plasenta, sehingga adanya IgM pada darah bayi menunjukkan adanya infeksi. Makromolekul IgM dapat menyebabkan aglutinasi berbagai partikel dan fiksasi komplemen dengan efisiensi yang sangat tinggi.

\section{(3). Imunoglobulin A}

Struktur imunoglobulin A umumnya berbentuk monomer dan terdapat $15 \%$ dari total imunoglobulin (terbanyak kedua dalam serum). IgA berfungsi dalam cairan sekresi yang diproduksi oleh sel sel plasma dalam jaringan limfoid, dan banyak ditemukan dalam saliva, air mata, kolostrum, serta sekret bronkus, vagina, dan prostat. IgA mampu mengikat mikroorganisme sehingga tidak melekat pada permukaan mukosa, dan membatasi absorpsi antigen yang berasal dari makanan. Imunoglobulin ini terdapat pada kolostrum yang dapat membantu sistem imun pada bayi baru lahir. IgA mempunyai half life selama 5-6 hari di dalam darah.

\section{(4). Imunoglobulin D}

Konsentrasi IgD hanya sedikit di dalam serum, namun cukup tinggi pada darah tali pusat. IgD ditemukan dalam 
permukaan sel $B$, terutama dalam sel $B$ neonatus. keberadaan IgD bersama dengan IgM pada permukaan limfosit diperkirakan saling membantu sebagai resptor antigen dalam mengendalikan aktivasi dan penekanan limfosit. IgD mempunyai half life selama 2-3 hari di dalam darah.

\section{(5). Imunoglobulin E}

Konsentrasi IgE dalam serum sangat rendah, hanya $0,0004 \%$ dari total imunoglobulin dan dapat ditemukan dalam cairan sekresi. IgE mempunyai kemampuan melekat pada permukaan mastosit atau basofil melalui reseptor Fc. Imunoglobulin E dikenal sebagai reagin pada reaksi sensitifitas tipe segera (immediate) seperti pada rinitis musiman, asma, urtikaria, dan reaksi anafilaktik. IgE banyak ditemukan pada penderita infeksi cacing (parasit). Parasit yang dilapisi oleh IgE akan lebih mudah dihancurkan oleh eosinofil.

Pada sistem golongan darah pada manusia normal, umumnya mempunyai anti A dan anti B yang secara alamiah terbentuk di dalam tubuh. Jenis antibodi ini terbentuk berlawanan dengan jenis antigen yang sudah ada. Misalnya, seseorang dengan antigen $A$ akan mempunyai anti B di dalam serum darahnya. Pada sistem golongan darah umumnya memiliki jenis antibodi IgM atau IgG, dan sedikit IgA. Antibodi seperti anti A dan anti B biasanya merupakan IgM. Sedangkan antibodi jenis IgG pada sistem golongan darah biasanya jenis antibodi imun, karena terbentuk akibat paparan sebelumnya dengan antigen yang sesuai, misalnya antibodi Rhesus, antibodi Kell, antibodi Kidd, dan lain-lain. Bila antibodi jenis IgM dapat bereaksi langsung pada medium saline ( $\mathrm{NaCl} 0,9 \%)$, maka jenis antibodi IgG membutuhkan reagen tambahan untuk 
memperlihatkan aglutinasi terhadap antigen yang sesuai, misalnya anti human globulin (AHG).

Tabel 1.2 Ciri-ciri Jenis Imunoglobulin

\begin{tabular}{|c|c|}
\hline Immunoglobulin G & $\begin{array}{l}\text { - Monomer; molecular weight } 180,000 \\
\text { - M } \\
\text { - Most abundant in serum; } 1^{0} \text { immune } \\
\text { - "Maternal } \mathrm{Ab} \text { "; crosses placenta } \\
\text { - Binds complement to destroy antigens } \\
\text { - } \text { - Is opsich havebeen bound } \\
\text { have high affinity for IgG Fc regions }\end{array}$ \\
\hline Immunoglobulin A & $\begin{array}{l}\text { - Dimeric, } 400 \text { kD } \\
\text { - Secreted by mucous membranes, in } \\
\text { mother's milk } \\
\text { - Does not bind complement }\end{array}$ \\
\hline Immunoglobulin M & $\begin{array}{l}\text { - Pentameric, } 900 \mathrm{kD} \\
\text { - Primary immune response } \mathrm{Ab} \text {; binds } \\
\text { complement }\end{array}$ \\
\hline Immunoglobulin D & $\begin{array}{l}\text { - Monomer, } 180 \text { kD } \\
\text { - B cell surface Ig? }\end{array}$ \\
\hline Immunoglobulin E & $\begin{array}{l}\text { - Monomeric, } 180 \mathrm{kD} \\
\text { - In allergy or anaphylaxis, binds mast } \\
\text { cell and allergen }\end{array}$ \\
\hline
\end{tabular}

(Quinley, 2011)

\subsection{MEKANISME RESPON IMUN}


Transfusi darah terutama berkaitan dengan produk dari antibodi sel B yang dibuat sebagai respon terhadap bahan antigenik seperti alogenik ("asing": dari donor selain resipien transfusi) eritrosit dan terkadang leukosit, trombosit, dan obat-obatan. Imunisasi, atau sensitisasi (paparan antigen asing yang menghasilkan respon imun) pada substansi ini, terjadi melalui transfusi darah atau kehamilan. Elemen seluler dari donor atau janin mengandung antigen yang dikenali oleh sistem imun resipien sebagai non-self. Ketika dipresentasikan kepada resipien, maka antigen ini diproses oleh sistem imun resipien serta dapat mengakibatkan pembentukan antibodi yang terdeteksi. Keadaan ini dapat terjadi pada $30 \%$ sampai dengan $70 \%$ dari semua orang yang ditransfusikan dengan komponen darah yang mengandung leukosit. Antibodi yang dibuat sebagai respon terhadap produk darah "asing" kemungkinan dari subkelas IgG atau IgM. Antibodi IgM umumnya merupakan hasil dari respon imun primer, memiliki konsentrasi yang relatif rendah serta dapat dideteksi dalam waktu 3-4 minggu. Pada paparan ulang antigen non-self, dapat terjadi respon sekunder dengan tipikal antibodi IgG yang diproduksi dalam 1 hingga 2 hari dalam jumlah yang jauh lebih besar daripada respon IgM. Respon sekunder dikenal sebagai respon anamnestik. Banyak faktor yang dapat mempengaruhi respon imun primer dan sekunder, misalnya imunogenisitas antigen, kelangsungan hidupnya dalam sirkulasi, dan kekuatan sistem imun resipien. Respon imun resipien ini tergantung pada faktor-faktor, seperti usia, status gizi, dan paparan sebelumnya.

\section{A. Mekanisme Aglutinasi}


Reaksi antigen-antibodi mengikuti hukum aksi massa dalam reaksi kombinasi sederhana ( $\mathrm{Ab}+\mathrm{Ag} \leftrightarrow$ kompleks $\mathrm{AbAg}$ ) yang kemudian diikuti oleh reaksi sekunder dan tersier. Reaksi bersifat reversibel dan tergantung pada beberapa faktor. Namun yang paling penting adalah kecocokan dari tempat pengikatan antibodi (binding site) dan antigen, saling melengkapi muatan, konsentrasi antigen dan antibodi, medium suspensi $\mathrm{pH}$, suhu, serta kekuatan ionik.

\section{B. Antibodi Mengikat Eritrosit}

Pengikatan eritrosit-antibodi untuk membentuk reaksi aglutinasi yang visible (terlihat), maka jumlah minimum molekul antibodi harus terikat dengan antigen. Sehingga semakin besar jumlah antibodi yang terikat pada setiap eritrosit maka semakin kuat reaksi yang dapat diamati. Selain itu, meningkatkan rasio serum terhadap sel memiliki efek adanya aglutinasi yang dapat diamati serta peningkatan uji sensitivitas. Sebaliknya, meningkatnya konsentrasi antigen oleh peningkatan kekuatan suspensi eritrosit pada sistem pengujian menghasilkan sensitivitas yang lebih rendah, dan lebih sedikit molekul antibodi yang terikat pada tiap eritrosit.

\section{Hemaglutinasi}

Tahap kedua dari reaksi antigen eritrosit-antibodi menyebabkan aglutinasi atau lebih tepatnya hemaglutinasi. Hemaglutinasi sebagai reaksi yang dapat diamati dapat terjadi atau tidak terjadi sebagai konsekuensi dari pasien yang diimunisasi dengan antigen sel darah merah alogenik, dan tergantung dari beberapa variabel, antara lain: jumlah dan tipe antibodi yang ada; ukuran, jumlah, dan lokasi antigen site yang tersedia; $\mathrm{pH}$, temperatur, dan kekuatan ion sistem pengujian. 
Anibodi golongan darah tergantung pada kelasnya. Dapat bereaksi dalam kisaran $4^{\circ} \mathrm{C}$ sampai dengan $37^{\circ} \mathrm{C}$, dan tingkat disosiasi meningkat ketika suhu meningkat lebih dari $37^{\circ} \mathrm{C}$. Prinsip ini digunakan dalam semua tes antigen-antibodi, mulai dari tes kompatibilitas hingga prosedur elusi antibodi yang menggunakan pemanasan untuk menghilangkan antibodi dari permukaan eritrosit. Suhu sangat berpengaruh pada reaksi antigen-antibodi, sebagai contoh ikatan anti-D lebih banyak dan efisien pada suhu $37^{\circ} \mathrm{C}$ daripada suhu $4^{\circ} \mathrm{C}$.

Tidak ada metode serologis tunggal yang dapat digunakan untuk mendeteksi semua jenis antibodi golongan darah. Hal ini disebabkan karena metode tunggal tidak dapat menunjukkan reaktivitas. Ini tidak berarti bahwa serum tidak mengandung antibodi spesifik, namun ini tidak dapat ditunjukkan oleh suatu teknik tertentu, pada suhu dan $\mathrm{pH}$ tertentu. Aglutinasi atau reaksi penggumpalan yang diamati secara in vitro karena adanya ikatan antigen dan antibodi serta semua variabel yang mempengaruhi karakter dan jumlah reaktivitas yang dapat diamati.

\section{Reaksi Tersier}

Step terakhir dalam pengikatan eritrosit-antibodi mengarah pada destruksi target eritrosit termasuk aktivasi komplemen, fagositosis, opsonisasi, kemotaksis, adherens imun, dan degranulasi seluler.

\section{RANGKUMAN :}


- Imunohematologi mencakup tentang imunologi dasar, penerapan konsep imunologi pada pemeriksaan laboratorium dan transfusi darah, serta komponen darah.

- Sistem imun non spesifik adalah pertahanan tubuh yang bersifat tidak spesifik dan berfungsi sebagai barier terdepan pada saat terjadinya infeksi penyakit, sehingga sering disebut natural atau native immunity.

- Sistem imun spesifik ialah sistem pertahanan tubuh kedua ketika sistem imun non spesifik tidak dapat mengeliminasi agen penyakit.

- Antigen (imunogen) merupakan substansi yang mampu bereaksi dengan antibodi yang diproduksi oleh sel B atas rangsangan imunogen, tanpa mempertimbangkan apakah antigen bersifat imunogenik. Ini artinya semua imunogen adalah antigen, namun tidak semua antigen adalah imunogen.

- Antibodi (imunoglobulin) dihasilkan oleh sistem imun dan penting untuk pencegahan dan perlawanan infeksi oleh substansi asing seperti bakteri, virus, parasit, dan zat patogen lainnya. Antibodi berupa glikoprotein yang berikatan khusus dengan substansi atau molekul asing yang disebut antigen.

- Terdapat lima jenis imunoglobulin (IgG, IgA, IgM, IgD, dan IgE) yang berbeda dalam urutan asam amino dan jumlah domain di area konstan pada rantai berat.

\section{LATIHAN SOAL :}


1. Ilmu yang mempelajari tentang imunitas atau kekebalan akibat adanya rangsangan molekul atau substansi asing dari luar maupun dari dalam tubuh adalah
a. Imunologi
b. Imunohematologi
c. Sistem Imun
d. Respon Imun
e. Mekanisme respon imun

2. Bagian dari antigen yang dapat berikatan dengan antibodi atau reseptor spesifik pada limfosit $\mathrm{T}$, disebut ..........
a. Imunogen
b. Imunoglobulin
c. Epitop
d. Hapten
e. Fagosit

3. Proses menghilangkan komponen darah leukosit (leucopoor) sebelum ditransfusikan dilakukan guna menghindari ketidakcocokan .......... antara pendonor dan resipien.
a. Golongan darah
b. HLA
c. HPA
d. Imunoglobulin
e. Imunogen

4. Imunoglobulin pertama yang dibentuk pada saat antigen masuk ke dalam tubuh, tetapi memiliki respon yang pendek adalah
a. $\lg G$
b. $\lg M$
c. $\lg A$ 

d. $\lg D$
e. IgE

5. Imunoglobulin yang dapat menembus plasenta dan masuk ke dalam sistem peredaran darah janin sehingga dapat melindungi bayi dari infeksi adalah ..........
a. IgG
b. $\lg M$
c. $\operatorname{Ig} A$
d. $\lg D$
e. IgE

6. Struktur yang umumnya berbentuk monomer dan terdapat $15 \%$ dari total imunoglobulin (terbanyak kedua dalam serum) dalah
a. $\lg G$
b. $\lg M$
c. $\lg A$
d. $\lg D$
e. IgE

7. Keasingan, ukuran molekul, dan kompleksitas struktur kimia. Merupakan beberapa ciri dari substansi yang memiliki sifat
a. Imunogenitas
b. Imunoglobulin
c. HLA
d. HPA
e. $\mathrm{MHC}$

8. Pertahanan fisik dan kimiawi, komponen sistem komplemen, mediator inflamasi, sitokin, dan sel fagosit. Merupakan contoh dari ...........
a. Sistem imun
b. Sistem imun non spesifik 

c. Sistem imun spesifik
d. Imunogenitas
e. Human Leucocyte Antigen

9. Antigen yang terdapat pada glikoprotein membran trombosit disebut
a. Golongan darah
b. HLA
c. HPA
d. Imunoglobulin
e. Imunogen

10. Struktur dasar antibodi terdiri dari
a. 1 rantai berat dan 1 rantai ringan
b. 2 rantai berat dan 2 rantai ringan
c. 1 rantai berat dan 2 rantai ringan
d. 2 rantai berat dan 1 rantai ringan
e. 4 rantai berat dan 4 rantai ringan 


\section{REFERENSI :}

Baratawidjaja, K., \& Rengganis, I. (2018). Imunologi Dasar. Edisi ke 12. Jakarta: FKUI.

Kumagai, I., \& Tsumoto, K. (2014). Antigen-Antibody Binding. Encyclopedia of Life Sciences, 1-7. https://doi.org/10.1002/9780470015902.a0001117.pub2 Kresno, S. B. (2010). Imunologi: Diagnosis dan Prosedur Laboratorium. Edisi Kelima. Jakarta: Balai Penerbit FKUI.

Maharani, E. A., \& Noviar, G. (2018). Imunohematologi dan Bank Darah. Jakarta: Pusat Pendidikan Sumber Daya Manusia Kesehatan Kemenkes RI.

Olson, K. R., \& Nardin, E. D. (2016). Imunologi dan Serologi Klinis Modern. Jakarta: EGC.

Playfair, J. H. L., \& Chain, B .M. (2012). At a Glance Imunologi. Edisi Kesembilan. Jakarta: Erlangga.

Quinley, E. D. (2011). Immunohematology Principles \& Practice. Third Edition. Philadelphia: Lippincott Williams \& Wilkins.

Rantam, F. A. (2003). Metode Imunologi. Surabaya: Airlangga University Press.

Whitlock, S. A. (2010). Immunohematology For Medical Laboratory Technicians. USA: Delmar, Cengage Learning.

Mekanisme Fagositosis. Retrieved from https://brainly.co.id/tugas/438737. 


\section{BAB 2 \\ SISTEM GOLONGAN DARAH}

\section{Sub - Capaian Pembelajaran Mata Kuliah :}

- Mampu memahami mengenai sistem golongan darah beserta aspek klinisnya.

- Mampu menjelaskan tentang sejarah, persebaran, antigen dan antibodi golongan darah $\mathrm{ABO}$, Fenotip Bombay, dan status sekretor.

- Mampu menjelaskan tentang sejarah, antigen, dan antibodi golongan darah Rhesus.

- Mampu memahami antigen dan antibodi golongan darah Lewis, Kell, Duffy, Kidd, MNS. 
Bidang utama dalam sistem golongan darah meliputi bank darah dan terapi transfusi darah. Sistem golongan darah dan antibodi merupakan dasar untuk pemeriksaan pra transfusi darah. Antigen dan antibodi merupakan etiologi penyakit hemolitik pada janin dan reaksi transfusi hemolitik pada bayi baru lahir. Beberapa antigen berperan utama pada terapi transplantasi. Pemeriksaan pra transfusi berfokus pada pemeriksaan antigen $A B O$ dan Rhesus, sera skrining untuk anibodi dalam plasma. Pada bab ini akan membahas tentang sistem golongan darah $\mathrm{ABO}$ dan Rhesus, serta sistem golongan darah lainnya.

Hingga saat ini diketahui terdapat 33 sistem golongan darah yang mewakili lebih dari 300 antigen yang terdaftar di International Society of Blood Transfusion (ISBT), dimana sebagian besar telah di kloning dan di sekuensing (diurutkan). Gen-gen dari sistem golongan darah ini bersifat autosomal, kecuali XG dan XK yang diturunkan melalui kromsom $\mathrm{X}$, dan $\mathrm{MIC} 2$ yang ada pada kromosom $\mathrm{X}$ dan $\mathrm{Y}$. Antigen dapat berupa protein integral dimana polimorfisme terletak pada variasi urutan asam amino (misalnya: Rhesus, Kell), glikoprotein atau glikolipid (misalnya $A B O$ ). Beberapa sistem golongan darah ada pada Tabel 2.1.a dan 2.1.b. Sedangkan fungsi dari berbagai sistem golongan darah ada pada Tabel 2.2.

\subsection{GOLONGAN DARAH ABO}

Sistem golongan darah $\mathrm{ABO}$ penting dalam bidang ilmu kedokteran terutama transfusi dan transplantasi. Sistem $A B O$ paling penting dalam bidang transfusi, karena transfusi sistem $A B O$ yang inkompatibel akan mengakibatkan gejala reaksi transfusi hemolitik (HTR) dan mengakibatkan koagulasi intravaskular diseminata (DIC), gagal ginjal, dan kematian. Terdapat 2 jenis inkompatibilitas ABO, yaitu: 
- Inkompatibilitas Mayor, di mana antibodi resipien akan menghancurkan eritrosit yang ditransfusikan (misalnya: A ke O, B ke $\mathrm{O}, \mathrm{A}$ ke $\mathrm{B}, \mathrm{B}$ ke $\mathrm{A}$ ).

- Inkompatibilitas Minor, di mana antibodi darah donor akan menghancurkan eritrosit resipien. (misalnya: O ke A, O ke B).

Inkompatibilitas mayor dalam transfusi darah harus dihindari. Walaupun inkompatibilitas minor biasanya dapat diabaikan ketika donor tidak memiliki antibodi $A B O$ yang levelnya sangat tinggi, bila memungkinkan untuk transfusi harus menggunakan darah donor dari golongan darah $\mathrm{ABO}$ yang sama dengan pasien. Tanda terjadinya destruksi eritrosit kemungkinan tampak setelah transfusi whole blood golongan darah $\mathrm{O}$ atau, dalam keadaan luar biasa, Packed Red Cell (PRC), kepada resipien golongan darah ABO lainnya. Ini menyebabkan destruksi eritrosit pasien karena ditransfusikannya antibodi $A B O$. Anti- $A_{1}$ jarang bermakna klinis secara signifikan dan sebagian besar sampel tidak aktif pada suhu lebih dari $25^{\circ} \mathrm{C}$, meskipun ada beberapa laporan HTR yang disebabkan oleh anti- $\mathrm{A}_{1}$.

Diantara 33 sistem golongan darah, sistem ABO merupakan yang paling penting dalam transplantasi dan transfusi darah. Hal ini disebabkan individu berusia lebih dari 6 bulan memiliki antibodi antiA dan atau anti-B yang bermakna signifikan secara klinis dalam serumnya. Golongan Darah A mengandung antibodi terhadap golongan golongan darah B dalam serum dan sebaliknya. Sedangkan golongan darah $\mathrm{O}$ tidak mengandung antigen $\mathrm{A}$ atau $\mathrm{B}$ tapi keduanya merupakan antibodi dalam serum.

Tabel 2.1.a Sistem Golongan Darah Utama

\begin{tabular}{llcclcc}
\hline $\begin{array}{l}\text { No. } \\
\text { ISBT }\end{array}$ & Nama & Simbol & $\begin{array}{l}\text { No. } \\
\text { Anti } \\
\text { gen }\end{array}$ & $\begin{array}{l}\text { Antigen } \\
\text { Utama }\end{array}$ & $\begin{array}{l}\text { Nama } \\
\text { Gen }\end{array}$ & $\begin{array}{c}\text { No. Lokasi } \\
\text { Kromosom }\end{array}$ \\
\hline 001 & ABO & ABO & 4 & $\mathrm{~A}, \mathrm{~B}, \mathrm{~A}_{1} \mathrm{~B}, \mathrm{~A}_{1}$ & $\mathrm{ABO}$ & 9
\end{tabular}




\begin{tabular}{|c|c|c|c|c|c|}
\hline 002 & MNS & MNS & 43 & $\mathrm{M}, \mathrm{N}, \mathrm{S}, \mathrm{s}, \mathrm{U}$ & $\begin{array}{l}\text { GYPA, } \\
\text { GYPB, } \\
\text { GYPE }\end{array}$ \\
\hline 003 & $P$ & P1 & 1 & P1 & P1 \\
\hline 004 & Rhesus & $\mathrm{Rh}$ & 49 & $D, C, E, c, e$ & $\begin{array}{l}\text { RhD, } \\
\text { RhCE }\end{array}$ \\
\hline 005 & Lutheran & LU & 20 & $\mathrm{Lu}^{\mathrm{a}}, \mathrm{Lu}^{\mathrm{b}}$ & LU \\
\hline 006 & Kell & KEL & 25 & $\begin{array}{l}\mathrm{K}, \mathrm{k}, \mathrm{Kp^{ \textrm {a } }}, \mathrm{Kp^{ \textrm {b } }}, \\
\mathrm{J} \mathrm{s}^{\mathrm{a}}, \mathrm{Js^{ \textrm {b } }}\end{array}$ & KEL \\
\hline 007 & Lewis & LE & 6 & $\mathrm{Le}^{\mathrm{a}}, \mathrm{Le}^{\mathrm{b}}$ & FUT3 \\
\hline 008 & Duffy & FY & 6 & $\mathrm{Fy}^{\mathrm{a}}, \mathrm{Fy}^{\mathrm{b}}, \mathrm{Fy} 3$ & $\mathrm{FY}$ \\
\hline 009 & Kidd & $\mathrm{Jk}$ & 3 & $\mathrm{Jk}^{\mathrm{a}}, \mathrm{Jk}^{\mathrm{b}}, \mathrm{Jk} 3$ & SLC14A1 \\
\hline
\end{tabular}

(Mitra et al., 2014; Smart \& Armstrong, 2008)

Tabel 2.1.b Sistem Golongan Darah Lain

\begin{tabular}{|c|c|c|c|}
\hline ISBT No & $\begin{array}{l}\text { Blood group } \\
\text { system name }\end{array}$ & Main antigens & $\begin{array}{l}\text { Chromosome } \\
\text { location no. }\end{array}$ \\
\hline 010 & Dicgo & $\mathrm{Di}^{2}, \mathrm{Dr}^{\mathrm{s}}, \mathrm{Wr}, \mathrm{Wr}$ & 17 \\
\hline 011 & $\mathrm{Yt}$ & $\mathrm{rt}^{3}, \mathrm{Yt}^{3}$ & 7 \\
\hline 012 & $\mathrm{X}_{g}$ & $x_{g^{*}}$ & $\mathrm{x}$ \\
\hline 013 & Scianna & $\mathrm{Sc} 1, \mathrm{Sc} 2$ & 1 \\
\hline 014 & Dombrock & $\mathrm{Do}^{2}, \mathrm{Do}, \mathrm{Gr}, \mathrm{Hy}, 10^{2}$ & 12 \\
\hline 015 & Colton & $\mathrm{Co}^{*}, \mathrm{Co}^{*}, \mathrm{Co} 3$ & 7 \\
\hline 016 & Landsteinct-Weiner & $\mathrm{tw}$ & 19 \\
\hline 017 & Chiso/Rodgers & CH/ROS & 6 \\
\hline 018 & $\mathrm{H}$ & H & 19 \\
\hline 019 & $\mathrm{Kx}$ & $k x$ & $x$ \\
\hline 020 & Gerbich & Ge2, Ge3, Ge4 & 2 \\
\hline$\alpha_{21}$ & Cromer & $c^{2}$ & 1 \\
\hline 022 & Knops & $\mathrm{Kn}^{2}, \mathrm{Kn}^{\mathrm{b}}$ & 1 \\
\hline 023 & Indian & $\ln ^{2}, \ln ^{6}$ & 11 \\
\hline 024 & Ok. & $O k^{2}$ & 19 \\
\hline 025 & Ralph & MER2 & 11 \\
\hline 026 & John Milton Hagan & JMH & 15 \\
\hline 027 & 1 & 1 & 6 \\
\hline 028 & Globoside & P & 3 \\
\hline 029 & Gill & Gill & 9 \\
\hline
\end{tabular}


(Smart \& Armstrong, 2008)

\section{A. Sejarah Golongan Darah ABO}

Pada tahun 1990 Karl Landsteiner menemukan sistem golongan darah ABO. Ini menjadi awal mula adanya bank darah dan kedokteran transfusi darah. Dengan serangkaian percobaan, Karl Landsteiner berhasil menemukan 3 dari 4 golongan darah dalam sistem golongan darah $\mathrm{ABO}$, yaitu $\mathrm{A}, \mathrm{B}$, dan $\mathrm{O}$. Kemudian tidak lama setelah itu, rekannya, yaitu Alfred von Decastello dan Adriano Sturli menemukan golongan darah $\mathrm{AB}$. Pada penelitian selanjutnya, Karl Landsteiner menghubungkan adanya antigen $A B O$ pada eritrosit dan antibodi aglutinasi resiprokal dalam serum orang yang sama, misalnya antigen A pada eritrosit dengan dengan anti-B pada serum. Penemuan ini dikenal dengan Hukum Landsteiner, yang merupakan dasar untuk semua terapi transfusi serta sebagai pedoman untuk menentukan kompatibilitas atau kecocokan antara donor dan resipien. Golongan darah ABO merupakan pemeriksaan utama yang dilakukan di bank darah.

Tabel 2.2 Berbagai jenis dan Fungsi Sistem Golongan Darah

\begin{tabular}{ll}
\hline Blood groups & Red cell function \\
\hline Rh, Kidd, Kx, Diego, Colton, & Membrane transporters \\
Gill & \\
Kell, Yt & Membrane bound enzymes \\
MNS, Gerbich & Structural proteins \\
Duffy & Chemokine receptor \\
Lutheran, LW, Xg, Indian & Cell adhesion molecules
\end{tabular}


Cromer, Knops

$A B O, H, I, P 1$ and $P$
Complement regulation

Carbohydrate structures

which contribute to the

glycocalyx

(Smart \& Armstrong, 2008)

\section{B. Persebaran Golongan Darah ABO di Dunia}

\section{(1) Golongan Darah 0}

Individu dengan golongan darah $\mathrm{O}$ disebut "donor universal" karena darah mereka kompatibel dengan semua golongan darah $\mathrm{ABO}$. Golongan darah ini yang paling banyak jumlahnya di seluruh dunia, termasuk Amerika Serikat dan Eropa Barat. Penduduk asli Amerika Tengah dan Selatan, memiliki frekuensi golongan darah $\mathrm{O}$ sangat tinggi, hampir 100\%. Golongan darah $\mathrm{O}$ juga banyak jumlahnya di antara penduduk asli Australia.

\section{(2) Golongan Darah A}

Golongan darah A banyak terdapat di Eropa Tengah dan Timur. Sekitar 45-50\% penduduk di negara Austria, Denmark, Norwegia, dan Swiss memiliki golongan darah A. Pada penduduk Polandia dan Ukraina populasi golongan darah O mencapai 40\%. Sekitar $80 \%$ orang Indian Blackfoot di Montana memiliki golongan darah A.

\section{(3) Golongan Darah B}

Golongan darah B banyak terdapat di Cina dan India, mencapai $25 \%$ dari populasinya. Golongan darah B jarang ditemukan di negara-negara Eropa dan penduduk Amerika yang berasal dari Eropa, hanya ditemukan sekitar 10\% dari populasi ini.

\section{(4) Golongan Darah AB}


Golongan darah $A B$ merupakan golongan darah yang paling langka. Individu golongan darah AB dikenal sebagai "resipien universal" karena dapat menerima transfusi darah dari semua golongan darah $\mathrm{ABO}$. Golongan darah $\mathrm{O}$ paling banyak terdapat di Jepang, wilayah Cina, dan di Korea, jumlahnya mencapai $10 \%$ dari populasi penduduknya.

\section{Antigen Sistem ABO dan $\mathrm{H}$}

Antigen yang terdeteksi pada pemeriksaan laboratorium, termasuk antigen $A B O$ terletak di permukaan eritrosit. Antigen $A B O$ juga ditemukan pada limfosit, trombosit, organ, sel endotel, dan sel epitel. Antigen $A B O$ berkembang dengan baik pada orang dewasa. Antigen ABO terdeteksi pada usia kehamilan $5-6$ minggu. Pada bayi baru lahir menunjukkan antigen yang lebih lemah namun antigen $A B O$ berkembang seutuhnya pada usia 2-4 tahun. Hal ini disebabkan oleh percabangan oligosakarida. Pada orang dewasa jumlah percabangan rantai lebih banyak, bila dibandingkan dengan bayi baru lahir yang lebih banyak memiliki rantai linier. Percabangan rantai memungkinkan perlekatan molekul ang lebih banyak untuk menentukan spesifitas antigen $H$, termasuk molekul spesifik $A$ dan atau $B$.

Pewarisan antigen $\mathrm{ABO}$ diperoleh dari kedua orangtua individu. Setiap individu mempunyai sepasang gen. Setiap gen menempati lokus identik pada kromosom 9. Terdapat kemungkinan 3 gen yang dapat diwariskan, yaitu A, B, dan O. Gen A dan B menghasikan produk yang dapat terdeteksi. Sedangkan gen $O$ merupakan produk yang tidak terdeteksi. Ekspresi gen A dan B adalah kodominan. Kombinasi gen (genotip) dan ekspresi sebagai golongan darah (fenotip) ada pada Tabel 2.4. Pewarisan golongan darah ABO dari kedua orangtua dapat dilihat pada Tabel 2.5. 
Antigen $\mathrm{H}$ merupakan prekursor dari antigen golongan darah $A B O$. Antigen $\mathrm{H}$ ada pada semua eritrosit, terlepas dari sistem $A B O$. Antigen $\mathrm{H}$ diperlukan untuk menghasilkan antigen $\mathrm{A}$ dan atau B. Gen $\mathrm{H}$ juga diwariskan dengan gaya mendelian dan menempati lokus pada kromosom 19. Setiap orangtua berkonstribusi satu gen, baik $\mathrm{H}$ atau h. Kemungkinan kombinasi yang dapat terjadi adalah $\mathrm{HH}, \mathrm{Hh}$, dan hh. Individu yang secara genetik $\mathrm{HH}$ atau $\mathrm{Hh}$ akan menghasilkan antigen $H$, dan dapat terdeteksi pada eritrositnya.

A.

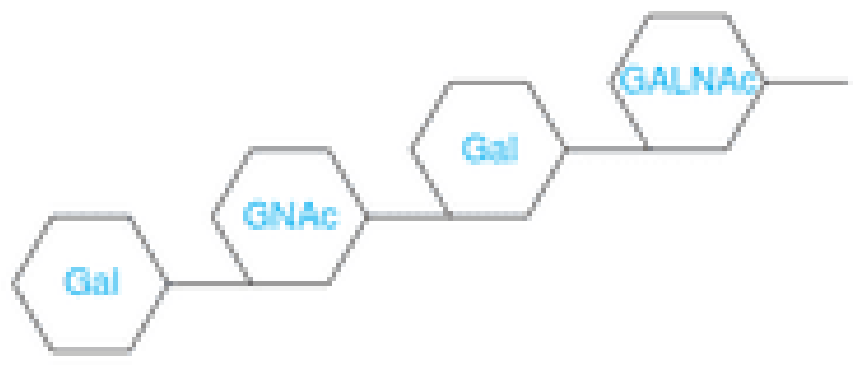

B.

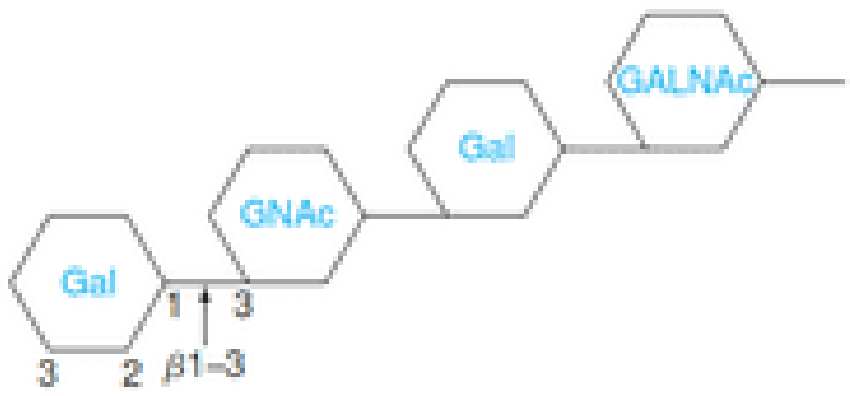


Gambar 2.1 Perbedaan Struktural Umum pada Rantai Oligosakarida yang Berfungsi sebagai Prekursor untuk Antigen $\mathrm{ABH}$ :
a). Rantai prekursor umum
b). Tipe 1 rantai oligosakarida $-\beta 1-3$ terikat D-galaktosa
c). Tipe 2 rantai oligosakarida $-\beta 1-4$ terikat D-galaktosa (Gal = D Galaktosa; GALNAC = N-asetilglukosamin)

Frekuensi munculnya antigen $\mathrm{H}$ pada populasi Kaukasia lebih dari 99,99\%. Sedangkan individu yang menghasilkan genotip hh tidak menghasilkan antigen $\mathrm{H}$ dan memiliki fenotip Bombay $\mathrm{O}_{\mathrm{h}}$. Plasma individu dengan fenotip Bombay sering menunjukkan anti-H. Individu dengan fenotip Bombay homozigot untuk gen $\mathrm{H}$ (hh) langka ditemukan. Fenotip Bombay tidak mengekspresikan antigen $\mathrm{H}$ pada eritrositnya. Antigen $\mathrm{H}$ berfungsi sebagai prekursor, sehingga ketidakhadirannya menandakan tidak adanya antigen $A$ dan $B$. Namun, individu tersebut menghasilkan isoantibodi terhadap antigen $\mathrm{H}$, serta antigen $A$ dan $B$.

Antigen $\mathrm{H}$ terdistribusi secara luas pada jaringan yang sama dengan antigen A dan B. Demikian juga pada individu "sekretor", dimana antigen $\mathrm{H}$ dalam bentuk terlarut ditemukan dalam saliva dan semua cairan tubuh, kecuali cairan serebrospinal. 


\section{Fenotip Defisiensi-H (Bombay $\mathrm{O}_{\mathrm{h}}$ )}

Meskipun sistem golongan darah $\mathrm{ABO}$ dan $\mathrm{H}$ berbeda secara genetik, namun keduanya berhubungan erat secara biokimia dan level fenotip. Fenotipe defisiensi-H sangat jarang dan meliputi: defisiensi total antigen $\mathrm{H}$ (Fenotip Bombay atau $\mathrm{O}_{\mathrm{h}}$ ) atau defisiensi parsial (Parabombay).

Individu $\mathrm{O}_{\mathrm{h}}$ Bombay sangat langka. Individu pertama yang terbukti pembawa sifat tersebut adalah orang India yang leluhurnya berasal dari Bombay, sehingga dinamakan $\mathrm{O}_{\mathrm{h}}$ Bombay. Sel-selnya tidak diaglutinasi oleh anti-A, anti-B, anti-A,B atau anti-H. Individu $\mathrm{O}_{h}$ Bombay mempunyai antibodi anti- $\mathrm{H}$, anti-A dan anti-B yang kuat di dalam serumnya. Sehingga mereka hanya bisa menerima transfusi hanya dengan golongan darah $\mathrm{O}_{\mathrm{h}}$. Tabel 2.3 menunjukkan perbedaan antara golongan darah $\mathrm{O}$ dan golongan darah $\mathrm{O}_{\mathrm{h}}$.

Tabel 2.3 Perbedaan Golongan darah $\mathrm{O}$ dan $\mathrm{O}_{\mathrm{h}}$

\begin{tabular}{cccccccc}
\hline & \multicolumn{2}{c}{ Forward Grouping } & \multicolumn{4}{c}{ Reverse Grouping } \\
Group & Anti-A & Anti-B & Anti-A,B & Anti- H & A cells & B cells & O cells \\
\hline O & 0 & 0 & 0 & 4 & 4 & 4 & 0 \\
$\mathrm{O}_{\mathrm{h}}$ & 0 & 0 & 0 & 0 & 4 & 4 & 4 \\
\hline
\end{tabular}

(Smart \& Armstrong, 2008)

Tabel 2.4 Genotip dan Fenotip Golongan Darah ABO

\begin{tabular}{cc}
\hline Kombinasi Gen (Genotip) & Fenotip \\
\hline AO & A \\
AA & A \\
BO & B \\
BB & B \\
AB & AB \\
OO & O \\
\hline
\end{tabular}

(Whitlock, 2010) 


\section{E. Perkembangan Biokimia dan Struktural Antigen A, B, Dan H}

Ekspresi gen $\mathrm{A}, \mathrm{B}$, dan $\mathrm{H}$ tidak menghasilkan produksi antigen secara langsung. Namun, masing-masing gen mengkode produksi enzim yang dikenal sebagai transferase. Setiap transferase mengkatalisis transfer molekul karbohidrat ke rantai oligosakarida. Karbohidrat yang terikat menyajikan spesifitas antigenik. Kode gen $\mathrm{O}$ untuk protein tidak akif secara enzimatik, sehingga tidak ada antigen yang diproduksi. Ringkasan dari molekul transferase ada pada Tabel 2.6 .

\section{F. Struktur Umum Golongan Darah}

Antigen $\mathrm{A}, \mathrm{B}$, dan $\mathrm{H}$ memiliki struktur umum berupa rantai oligosakarida yang terikat pada protein atau molekul lipid. Struktur umum ini yang digunakan sebagai komponen struktural dasar untuk beberapa antigen. Berbagai sistem antigen dibangun dari struktur yang sama, menandakan saling mempengaruhinya sistem terkait. Antigen dengan struktur dasar umum, antara lain: $A B H$, Lewis, $P$, dan I/i. Struktur oligosakarida yang umum adalah molekul karbohidrat yang terhubung dalam bentuk linier sederhana maupun struktur kompleks dengan tingkat percabangan yang tinggi. Terdapat dua variasi pada rantai oligosakarida, yaitu tipe 1 dan tipe 2. Perbedaan berdasarkan struktural perlekatan molekul gula terminal. Hal ini ditunjukkan pada Gambar 2.1. Rantai tipe 1 terdapat pada cairan dan sekresi tubuh sedangkan rantai tipe 2 ditemukan pada membran eritrosit. Rantai tipe 1 dibentuk oleh $\beta 1 \rightarrow 3$ ikatan karbon nomor 1 $\mathrm{D}$-galaktosa dengan karbon nomor $3 \mathrm{~N}$-asetilglukosamin. Sedangkan rantai tipe 2 dibentuk oleh hubungan $\beta 1 \rightarrow 4$ dari karbon nomor $1 \mathrm{D}$ galaktosa dengan karbon nomor 4 dari $\mathrm{N}$-asetilglukosamin.

Tabel 2.5 Tabel Pewarisan Golongan Darah 


\begin{tabular}{lcccc}
\hline \multicolumn{2}{l}{$\begin{array}{l}\text { Genotip ABO pada } \\
\text { keturunan }\end{array}$} & & \multicolumn{3}{c}{ Alel ABO diwariskan dari ibu } \\
\hline Alel ABO & A & A & B & O \\
diwariskan & B & AB & AB & A \\
dari ayah & O & A & B & B \\
\hline
\end{tabular}

(Dean, 2005)

Tabel 2.6 Enzim Transferase untuk Produksi Antigen ABH

\begin{tabular}{cl}
\hline Gen & \multicolumn{1}{c}{ Transferase } \\
\hline H & $\alpha$-L-fucosyltransferase \\
A & $\alpha-3-N$-acetyl-D-galactosaminyl Transferase \\
B & $\alpha-3-D$-acetyl-D-galactosyl Transferase \\
O & No Transferase Produced \\
\hline
\end{tabular}

(Whitlock, 2010)

\section{G. Status Sekretor}

Bentuk antigen $\mathrm{A}, \mathrm{B}$, dan $\mathrm{H}$ yang larut (soluble) dapat ditemukan dalam cairan sekresi tubuh. Kemampuan seseorang untuk mensekresikan substansi larut dalam cairan tubuh (water soluble) dikendalikan oleh gen yang diwariskan secara bebas. Gen sekretor adalah gen atau FUT2 ( $\alpha$ 1,2 fucosyltransferase) pada kromosom 19. Alelnya adalah se bersifat amorf. Membutuhkan minimal satu gen Se untuk memunculkan sifat sekretori. Individu yang memiliki antigen $\mathrm{ABH}$ terlarut (SeSe atau Sese) dalam cairan sekresi tubuhnya disebut sekretor. Sedangkan individu yang tidak memiliki antigen A atau B di cairan sekresi tubuhnya (sese) disebut non sekretor.

Terdapat sekitar $78 \%$ populasi yang memiliki minimal satu gen Se. individu yang memiliki gen Se akan mengeluakan antigen $A, B$, dan atau $\mathrm{H}$. Enzim yang diproduksi oleh Se bekerja terutama pada rantai tipe 1 dan secara khusus di kelenjar sekretori. Berbeda dengan gen $\mathrm{H}$ yang bekerja hampir seluruhnya pada rantai tipe 2 . Dan sebagian 
besar pada membran eritrosit. Kode gen Se untuk produksi transferase,L-fucosyltransferase. Enzim ini mendorong transfer Lfucose ke terminal galaktosa rantai tipe 1 dan membentuk zat $\mathrm{H}$ dalam cairan sekresi tubuhnya. Enzim transferase $A$ dan $B$ ditemukan dalam sekresi individu A dan B terlepas dari status sekretornya. Oleh karena itu ketika substansi $\mathrm{H}$ ditemukan pada cairan sekresi tubuh maka antigen A dan atau B akan terbentuk jika terdapat enzim transferase yang sesuai. Contoh cairan tubuh yang terdapat substansi A, B dan $\mathrm{H}$ antara lain: saliva, keringat, air mata, semen, serum, dan cairan amniotik (air ketuban).

\section{H. Subgrup A dan B}

\section{(1) Subgrup $A_{1}$ dan $A_{2}$}

Antigen grup $A$ dibedakan menjadi beberapa subgrup. Terdapat 2 grup utama yaitu $\mathrm{A} 1$ ( $80 \%$ individu grup A) dan A2 (20\% individu grup $A$ ). Individu dengan tipe $A B$ dapat dibagi ke dalam persentase yang sama dari presentasi antigen. $A_{1} B$ membentuk sekitar $80 \%$ dan $A_{2} B$ sebanyak $20 \%$ dari semua individu $A B$. Grup A individu yang tersisa berada dalam salah satu dari banyak subgrup minor.

Antigen $A_{1}$ dan $A_{2}$ memiliki beberapa perbedaan secara kualitatif dan kuantitatif. Antigen eritrosit memiliki jumlah antigen yang berbeda pada permukaan selnya. Gen $A_{1}$ menghasilkan transferase yang mempunyai kemampuan mengubah antigen $\mathrm{H}$ menjadi antigen $A$ lebih besar daripada gen $A_{2}$. Hal ini dikarenakan jumlah transferase yang diproduksi $A_{1}$ dan $A_{2}$ juga berbeda. $A_{1}$ memproduksi 5 hingga 10 kali lebih banyak daripada jumlah tranferase yang dihasilkan oleh $A_{2}$. Adanya fenotip $A_{2}$ ini 
disebabkan oleh 2 mutasi, yaitu substitusi Pro-156Leu dan delesi single nukleotida. Inilah yang menyebabkan aktivitas enzim transferase pada $A_{2}$ lebih sedikit daripada $A_{1}$.

Antigen $A_{2}$ sebagian besar terdiri dari rantai oligosakarida linier sedangkan $A_{1}$ memiliki jumlah rantai yang bercabang lebih banyak. Pada pemeriksaan rutin, perbedaan secara kualitatif tidak dapat terdeteksi namun dapat ditentukan secara biokimia. $A_{1}$ dan $A_{2}$ tidak dapat dibedakan menggunakan antisera umum, karena sama-sama bereaksi dengan anti $A$, dan anti $A, B$. Lectin, dan Dolichos biflorus dapat digunakan untuk untuk mendapatkan ekstrak dengan spesifitas anti $A_{1}$. Dolichos biflorus dapat bereaksi secara khusus dengan sel $A_{1}$ dan hasilnya negatif dengan $A_{2}$.

Individu $A_{2}$ dapat mengembangkan antibodi terhadap antigen $A_{1}$. Pola reaksi reverse yang khas dari individu golongan darah $A$ yaitu tidak terjadi aglutinasi dengan sel $A$ (tidak ada antiA) dan terjadi aglutinasi dengan sel $B$ (ada anti-B). Pada orang $A_{2}$ dengan anti $A_{1}$, sel-sel $A$ juga akan diaglutinasi oleh golongan darah A. Sehingga perbedaan ini harus dikonfirmasi melalui pengujian eritrosit dengan Dolichos biflorus lectin. Terdapat subgrup $A$ lain yang jarang muncul, serta dipengaruhi secara genetik. Subgrup ini antara lain: $A_{i n t r}, A_{3}, A_{x}, A_{m}, A_{e n d}, A_{e l}$, dan $A_{\text {bantu. }}$.

\section{(2) Subgrup B}

Subgrup B sangat jarang, dan jarang ditemukan dibandingkan dengan subgrup A. Metode untuk mendeteksi dan mengklasifikasikan subgrup $B$ mirip dengan yang digunakan pada subgrup $A$. Subgrup $B$ antara lain: $B_{3}, B_{x}, B_{m}$, dan $B_{\text {el }}$.

\section{Antibodi ABO}

Sistem imun membentuk antibodi terhadap antigen golongan darah $A B O$ mana pun yang tidak ditemukan pada eritrosit individu. 
Dengan demikian, individu golongan darah $\mathrm{A}$ akan memiliki antibodi anti-B dan individu golongan darah $B$ akan memiliki antibodi anti-A. Golongan darah $\mathrm{O}$ akan memiliki baik anti-A dan anti-B dalam serumnya. Golongan darah $A B$ yang paling jarang, dan mereka tidak memiliki anti-A atau anti-B dalam serumnya. Ini dapat dilihat pada Tabel 2.7.

Antibodi ABO dalam serum diperoleh secara alami, produksinya di stimulasi ketika sistem imun bertemu dengan antigen golongan darah ABO yang "hilang" dalam makanan atau dalam mikroorganisme. Ini terjadi pada usia dini karena gula yang identik dengan, atau sangat mirip dengan antigen golongan darah $A B O$ yang ditemukan diseluruh alam. Lokus $A B O$ mempunyai 3 bentuk alel utama, yaitu: A, B, dan O. Alel A mengkodekan glikosiltransferase yang menghasilkan antigen $\mathrm{A}$ ( $\mathrm{N}$-asetilgalaktosamin merupakan gula immunodominannya), dan alel B mengkodekan glikosiltransferase yang menghasilkan antigen B (D-galaktosa merupakan gula imunodominannya). Antibodi $A B O$ memiliki signifikansi klinis utama disebabkan 2 hal, yaitu: (1) karena terjadi secara alami dan ditemukan secara universal, serta (2) bersifat sangat reaktif.

Tabel 2.7 Antigen dan Antibodi Golongan Darah ABO

\begin{tabular}{cllc}
\hline $\begin{array}{c}\text { Golongan } \\
\text { Darah }\end{array}$ & $\begin{array}{c}\text { Antigen pada } \\
\text { eritrosit }\end{array}$ & $\begin{array}{c}\text { Antibodi pada } \\
\text { plasma/ } \\
\text { serum }\end{array}$ & Genotip \\
\hline A & antigen A & anti-B & AA atau AO \\
B & antigen B & anti-A & BB atau BO \\
AB & antigen A dan & tidak ada & AB \\
& antigen B & anti-A dan & OO \\
O & tidak ada & anti-B & \\
& & &
\end{tabular}

(Dean, 2005) 
Antibodi sistem $A B O$ hadir segera setelah kelahiran pada paparan agen lingkungan yang susunan antigennya mirip dengan antigen $A$ dan $B$ yang ditemukan pada eritrosit. Konsentrasi atau titer antibodi ini sangat bervariasi. Antibodi NRCS (non-red cell stimulated) sistem ABO pada dasarnya merupakan IgM, walaupun juga ditemukan adanya IgG dan IgA. Antibodi ini mengikuti sifat umum dari antibodi IgM (bereaksi paling baik pada suhu kamar atau dibawahnya, dapat mengaktifkan komplemen,dan merupakan aglutinin saline). Versi IgM dan IgA dari antibodi ABO tidak menembus barier plasenta. Namun, versi IgG mampu menembus plasenta serta dapat menyebabkan penyakit hemolitik pada bayi baru lahir.

Bentuk imunitas antibodi $A B O$ merupakan hasil dari paparan terhadap eritrositin kompatibel atau sumber antigen BO lainnya. Bentuk imunitas ini umumnya menjadi IgG, menyebabkan meningkatnya resiko transfer transplasental dari antibodi $A B O$ pada masa kehamilan. Kemudian, bentuk imunitas dari antibodi $A B O$ tidak mudah dihambat oleh antigen A dan B yang bersifat soluble. Hal ini menunjukkan bahwa antibodi yang timbul akibat sensitisasi eritrosit mampu mendeteksi perbedaan halus antara rantai prekursor tipe I dan tipe II yang menghasilkan antigen $\mathrm{A}$ dan $\mathrm{B}$.

\section{(1) Anti-A}

Anti-A terdapat dalam serum individu golongan darah $B$ yang terpapar agen lingkungan yang mirip dengan antigen $A$ dan akan menyebabkan aglutinasi eritrosit dari individu golongan darah A dan AB. Sebagian besar anti-A ini adalah IgM, meskipun kemungkinan ada IgG dan IgA dalam jumlah kecil. Karena itu, anti-A dapat menyebabkan aglutinasi eritrosit yang tersuspensi dalam saline dan mengaktifkan komplemen dengan mudah. Hal 
ini dapat menyebabkan destruksi intravaskular yang cepat dari eritrosit yang membawa antigen A. Secara fungsional anti-A dapat dibagi menjadi dua komponen, yaitu anti-A1, yang bereaksi dengan sel $A_{1}$ namun tidak bereaksi dengan sel $A_{2}$, dan anti- $A$ umum, yang bereaksi dengan sel $A_{1}$ dan $A_{2}$. $A_{1}$ dan $A_{2}$ adalah dua subkelompok $A$ yang paling umum, masing-masing mewakili sekitar $80 \%$ dan $20 \%$ dari total jumlah golongan darah $A$. Sedangkan subgrup lain sangat jarang ditemukan.

Meskipun secara fungsional dapat dibedakan, anti- $A_{1}$ ini juga dapat ditunjukkan dengan menghilangkan sel $A_{2}$ pada adsorpsi lengkap. Ini dapat dijelaskan oleh sedikit perbedaan dalam antigen umum pada permukaan eritrosit pada individu $A_{2}$. Seperti yang telah dijelaskan sebelumnya bahwa terdapat perbedaan pada antigen antara eritrosit individu $A_{1}$ dan $A_{2}$ yang terletak pada jumlah relatif percabangan yang terjadi pada struktur prekursor untuk antigen $\mathrm{ABH}$. Antigen $\mathrm{A}_{1}$ lebih bercabang sehingga bereaksi berbeda dengan anti-A daripada antigen $A_{2}$ yang bercabang lebih sedikit. Ini juga menjelaskan mengapa pada bayi baru lahir,yang awalnya sebagai $A_{2}$, pada akhirnya akan mengekspresikan fenotip $A_{1}$. Dengan demikian, antibodi yang dikenal sebagai anti-A umum sebenarnya dapat menjadi bentuk anti-A yang bereaksi berbeda karena hambatan sterik yang disebabkan oleh antigen $A_{1}$ yang bercabang-cabang.

\section{(2) Anti-A}

Anti-A dari individu golongan darah $B$, ketika dicampur dengan sel $A_{2}$, dapat menyebabkan adsorpsi dari komponen anti$A$ yang disebut anti-A umum, membiarkan komponen dengan aktivitas anti- $A_{1}$ yang jelas. Pereaksi ini disebut anti- $A_{1}$ (teradsorpsi) dan dapat digunakan untuk membedakan antara sel $A_{1}$ dan $A_{2}$. Pereaksi yang dibuat dari tanaman Dolichos biflorus 
(lektin), bila diencerkan dengan benar, reagen ini dapat digunakan untuk membedakan antara sel $\mathrm{A}_{1}$ dan $\mathrm{A}_{2}$.

\section{(3) Anti-B}

Serum dari individu golongan darah Amengandung antibodi yang pada dasarnya mengalami aglutinasi (penggumpalan) pada golongan darah $B$ dan $A B$. Anti-B, seperti anti-A, muncul paling sering sebagai IgM tanpa stimulasi eritrosit, serta mungkin memiliki IgG dan IgA dalam jumlah kecil. Bentuk imunitas antibodi ini bereaksi serupa dengan bentuk imunitas anti-A. Antibodi ini dengan mudah menggumpalkan sel-sel yang tersuspensi dalam saline, mengaktifkan komplemen, dan dapat dengan cepat menghancurkan eritrosit yang inkompatibel melalui hemolisis intravaskular. Sedangkan subgrup B yang lemah dapat bereaksi berbeda dengan anti-B.

\section{(4) Anti-A, B}

Anti-A, B ditemukan dalam serum semua individu golongan darah $O$ bersama dengan beberapa komponen anti-A dan anti-B. Anti-A, B bukan hanya campuran anti-A dan anti-B, seperti yang dapat ditunjukkan oleh adsorpsi diferensial dengan sel $A$ atau $B$. Salah satu dari sel-sel ini mampu menyerap sepenuhnya semua aktivitas anti-A atau anti-B. selanjutnya, ketika uji elusi dilakukan, aktivitas anti-B dapat ditunjukkan oleh antibodi yang bereaksi dengan sel $A$, dan aktivitas anti-A dapat ditunjukkan oleh antibodi yang dielusi dari sel $B$. Antibodi tidak hanya mampu bereaksi dengan sel-sel $A$ atau $B$, namun umumnya memiliki titer dan aviditas yang lebih tinggi daripada NRCS anti-A atau anti-B.

Ini yang menyebabkan anti-A, B dapat digunakan untuk mengkonfirmasi donor golongan darah $\mathrm{O}$, dalam pemeriksaan sampel darah bayi baru lahir, dan dapat membantu 
mengidentifikasi subgrup A dan B yang lemah. Bentuk IgG anti-A, $B$ lebih mungkin terjadi pada serum individu golongan darah $O$ yang telah peka oleh antigen $A$ atau $B$. Oleh karena itu, ibu golongan darah $O$ lebih cenderung memiliki IgG anti-A, B dalam serum mereka ketika membawa janin golongan darah $A$ atau $B$. Janin tersebut kemungkinan besar akan menderita penyakit hemolitik pada bayi baru lahir dari bentuk IgG anti-A, B dalam hubungannya dengan IgG anti-A atau anti-B atau dari anti-A, B saja. Ini harus selalu dipertimbangkan ketika eluat dari sampel bayi baru lahir diuji inkompatibilitas ABO. Antibodi pada permukaan eritrosit bayi baru lahir kemungkinan besar adalah anti-A, B dan harus dilaporkan demikian.

\section{(5) Anti-H}

Anti-H dapat ditemukan sebagai antibodi yang lemah dan bereaksi dalam temperatur rendah dalam serum grup $A_{1}$ dan menjadi individu $A_{1} B$. Ini juga ditemukan sebagai antibodi NRCS yang kuat dalam serum orang yang mengekspresikan fenotip Bombay (Oh). Antigen $\mathrm{H}$ yang ada pada individu $\mathrm{A}_{1}$ dan $\mathrm{A}_{1} \mathrm{~B}$ adalah yang konsentrasinya paling rendah dari semua golongan darah $A B O$. Ini dapat menyebabkan kegagalan dalam untuk mengenali antigen $\mathrm{H}$ sebagai "self" dan untuk membuat antibodi terhadap $\mathrm{H}$. $\mathrm{Hal}$ Ini merupakan penjelasan untuk anti-H yang lemah dimana terkadang ada dalam serum individu $A_{1}$ dan $A_{1} B$.

Reagen dengan aktivitas anti-H dapat dibuat dari tanaman U. europaeus. Ketika diencerkan dengan benar, lektin ini dapat berdiferensiasi di antara sel denganberbagai konsentrasi antigen $\mathrm{H}$ dan dapat digunakan untuk menguji status sekretor. Eritrosit fenotip Bombay ketika diuji dengan anti-H atau U. europaeus lectin, akan menunjukkan hasil negatif. 


\section{J. Acquired Changes}

Pada kasus yang jarang terjadi, individu golongan darah $A$ dapat memperoleh antigen $B$ dan menjadi golongan darah $A B$, walaupun antigen $B$ pada umumnya lemah dan terdapat beberapa pelemahan antigen A. Pada banyak kasus, fenomena ini terjadi pada pasien dengan penyakit pada saluran pencernaan, seperti kanker usus besar. Menurut penjelasan secara umum, adanya antigen $B$ diakibatkan karena enzim bakteri dalam darah menghilangkan gugus asetil dari GalNAc, gula imunodominan antigen $A$, untuk menghasilkan galaktosamin, yang cukup mirip dalam strukturnya dengan Gal, gula antinominan B antigen B, untuk bereaksi saling silang dengan beberapa anti-B.

Melemahnya antigen A umumnya terjadi pada pasien golongan darah $A$ dengan leukemia myeloid akut (AML). Pada beberapa kasus, semua eritrosit menunjukkan kelemahan dari antigen $A$, sedangkan pada populasi lainnya eritrosit $A$ dan $O$ bersifat jelas (tidak lemah). Perubahan yang berhubungan dengan leukemia pada antigen $\mathrm{B}$ dan $\mathrm{H}$ jarang terjadi. Sekitar $17 \%$ hingga $37 \%$ pasien dengan leukemia memiliki ekspresi antigenik $A, B$, atau $\mathrm{H}$ yang secara signifikan lebih rendah bila dibandingkan dengan kontrol yang sehat. Terkadang, modifikasi antigen $\mathrm{ABH}$ muncul sebelum pasien di diagnosis malignansi/ keganasan dan ini mengindikasikan keadaan praleukaemia. Efek leukemia ini mungkin berasal dari epigenetik, yang merupakan hasil dari hipermetilasi daerah promotor $A B O$.

\section{K. Hubungan Dengan Penyakit dan Aspek Fungsional}

Beberapa hubungan lain antara golongan darah $A B O$ dan penyakit telah dilaporkan, sebagian besar berdasarkan pada perbedaan frekuensi fenotip $A B O$ yang diamati antara pasien dengan penyakit kemudian dibandingkan dengan orang yang sehat. Misalnya, individu golongan darah A tampak lebih rentan terhadap 
karsinoma lambung dan usus besar daripada golongan darah $A B O$ lain.

Individu golongan darah $\mathrm{O}$ memiliki risiko trombosis yang lebih rendah dibandingkan dengan fenotip $A, B$, dan $A B$. Ini dapat diakibatkan karena adanya gula imunodominan $A$ dan $B$ pada faktor glikoprotein von Willebrand (vWF), faktor koagulasi yang terkait dengan Faktor VIII, sebagian menghalangi akses ADAMTS13, enzim yang bertanggung jawab untuk pembersihan vWF dari plasma. Individu golongan darah $\mathrm{O}$ tampaknya relatif tahan terhadap malaria berat yang disebabkan oleh infeksi Plasmodium falciparum, dibandingkan dengan individu selain golongan darah $\mathrm{O}$.

Hampir tidak ada yang diketahui tentang fungsi antigen $A B O$, baik pada eritrosit maupun di bagian tubuh lainnya. Antigen $A B H$ jumlahnya sangat banyak pada eritrosit. Antigen $\mathrm{ABH}$ berkontribusi pada glikokaliks atau cell coat, yaitu sebuah matriks karbohidrat ekstraseluler yang melindungi sel dari kerusakan mekanis dan serangan oleh mikroorganisme patogen.

\subsection{GOLONGAN DARAH RHESUS}

Golongan darah Rhesus merupakan salah satu golongan darah paling kompleks pada manusia. Penemuannya dinamakan dari salah satu jenis monyet, yaitu Rhesus. Sistem Rhesus telah menjadi golongan darah terpenting kedua setelah $\mathrm{ABO}$ di bidang transfusi darah. Sistem Rhesus sangat penting dalam bidang obstetri, karena menjadi penyebab utama penyakit hemolitik pada bayi baru lahir atau Hemolytic Disease of the Newborn (HDN).

Kompleksitas antigen golongan darah Rh dimulai dengan gen yang sangat polimorfik yang menyandikannya. Ada dua gen yang berhubungan erat, yaitu RHD dan RHCE. Berbagai pengaturan genetik di antara keduanya telah menghasilkan gen-gen Rh hibrida yang 
mengkodekan banyak sekali antigen Rh yang berbeda. Hingga saat ini diketahui terdapat 49 antigen $\mathrm{Rh}$.

Golongan darah Rh penting karena bersifat sangat imunogenik. Pada kasus antigen $D$, individu yang tidak mempunyai antigen $D$ akan menghasilkan anti-D jika mereka menemukan antigen $D$ pada eritrosit yang ditransfusikan, sehingga mengakibatkan reaksi transfusi hemolitik (HTR) atau pada eritrosit janin akan menyebabkan HDN. Karena itu, status Rh secara rutin di uji dalam donor darah, resipien transfusi, dan calon ibu.

\section{A. Sejarah Golongan Darah Rhesus}

Sistem golongan darah Rhesus ditemukan di New York pada tahun 1939. Awalnya ditemukan dalam antibodi pada serumseorang wanita yang melahirkan bayi dalam keadaan meninggal serta mengalami reaksi hemolitik setelah memperoleh transfusi darah dari suaminya. Levine dan Stetson menemukan bahwa antibodi menggumpalkan eritrosit suami wanita tersebut dan $80 \%$ donor darah $A B O$ yang kompatibel. Namun, Levine dan Stetson belum menyebutkan nama antibodi tersebut.

Pada tahun 1940, Landsteiner dan Wiener membuat antibodi dengan menyuntikkan eritrosit monyet rhesus ke tubuh kelinci. Antibodi ini tidak hanya menyebabkan aglutinasi pada eritrosit monyet rhesus, namun juga eritrosit dari $85 \%$ warga kulit putih New Yorkdan tampaknya sama dengan antibodi Levine dan Stetson dan antibodi manusia lainnya yang telah diidentifikasi sebelumnya. Namun pada tahun 1962, diketahui bahwa anti-rhesus kelinci dan marmut bereaksi dengan antibodi lain yang secara genetik tidak berkaitandengan antibodi manusia, meskipun secara serologis terkait. Karena itu, antibodi anti-rhesus diubah namanya menjadi anti-LW, setelah Landsteiner dan Wiener, dan antibodi manusia tetap sebagai anti-D dari sistem golongan darah Rh (bukan rhesus). LW 
diekspresikan lebih kuat pada eritrosit D+ daripada D-, menjelaskan kesalahan awal karena antiserum yang lemah sering gagal mengaglutinasikan eritrosit D-.

\section{B. Antigen Rh}

Sama seperti sistem $A B O$, antigen Rh terletak di permukaan eritrosit. Berbeda dengan sistem $\mathrm{ABO}$, antigen Rh utama ditemukan secara eksklusif pada eritrosit dan bukan pada sel jaringan atau dalam bentuk larut pada cairan tubuh. Sifat biokimia antigen RhD dan RhCE berupa protein. Protein berikatan dengan lipid pada membran eritrosit sebagai penunjang morfologinya. Masing-masing antigen terdiri dari 416 asam amino. Rangkaian asam amino dililitkan melalui membran eritrosit dan memperlihatkan lilitan pendek pada bagian luar. Asam amino aktif bervariasi dengan pengkodean genetik individu. Antigen Rh merupakan bagian integral dari membran eritrosit. Teori ini didukung oleh fakta bahwa sel-sel tanpa antigen $\mathrm{Rh}$ $\left(R h_{\text {null }}\right)$, menunjukkan morfologi yang berubah dan penurunan masa hidup eritrosit.

Glikoprotein yang berhubungan dengan struktur biokimia sistem Rh telah diidentifikasi. Glikoprotein ini tidak berkaitan dengan sifat antigenik sistem golongan darah mana pun, namun lebih berhubungan dengan membran eritrosit. Glikoprotein ini berperan dalam hubungan RhD dan RhCE dengan membran eritrosit. Glikoprotein yang berhubungan dengan membran eritrosit ini adalah RhAG. Adanya mutasi atau tidak adanya glikoprotein ini dapat menyebabkan kurangnya ekspresi antigen $\mathrm{Rh}\left(\mathrm{Rh}_{\text {null }}\right)$.

Adanya glikoprotein sebanding dengan yang diidentifikasi pada otak, hati, ginjal, dan kulit. Glikoprotein ini telah diberi label RhBG dan RhCG, dan tidak berhubungan dengan antigen golongan darah tertentu, namun penelitian menunjukkan keterlibatan dengan transportasi amoniak. 


\section{Genetika Sistem Golongan Darah Rh}

Gen-gen pada sistem Rh terletak pada Kromosom 1. Komposisi genetik sistem Rh mencakup dua gen yang terletak berdekatan, yaitu RhD dan RhCE. Gen-gen ini menyandi protein RhD dan RhCE. Protein RhD membawa antigen D sedangkan RhCE membawa antigen $C$ dan E. $C$ dan $E$ dapat hadir dalam berbagai kombinasi (misalnya: $C E$, $c e$, $\mathrm{Ce}, \mathrm{cE}$ ). Tidak ada komponen antitesis untuk antigen RhD. Sehingga, tidak ada huruf "d". Tidak adanya antigen D menunjukkan absensi atau delesi di lokasi ini. Ini sesuai dengan fenotip Rh negatif atau D negatif. Kurangnya material antigenik merupakan penyebab dari tidak adanya gen RhD.

Gen RhD dan RhCE masing-masing memiliki 10 ekson, dimana 97\% identik, dan kemungkinan besar muncul dari duplikasi gen. Komposisi asam amino RhD dan RhCE berbeda sejumlah 32 hingga 35 dari total 416 asam amino. Perbedaan antigen antitetis (misalnya: C dan c merupakan antitesis) dihasilkan dari perbedaan asam amino yang lebih sedikit daripada perbandingan antigen dari golongan darah alternatif. Fakta ini juga menjelaskan tingkat keasingan yang besar ketika RhD antigen dimasukkan ke dalam individu RhD negatif. Sifat antigenik RhD yang sangat antigenik berbeda dengan sistem antigen lainnya.

Teori Fisher-Race menggambarkan pewarisan Rh yang dihasilkan dari tiga lokus. Pada teknik molekuler, teori ini merupakan teori yang paling dekat menggambarkan warisan sistem Rh yang sebenarnya. Secara historis, Weiner mengusulkan satu gen dengan salah satunya memiliki dua atau tiga faktor. Nomenklatur Rosenfield bersifat numerik dan dikembangkan untuk membantu dalam konversi terminologi dengan menggunakan perangkat lunak komputer. ISBT merupakan pengembangan dari nomenklatur Rosenfield. Tata nama penulisan sistem golongan darah Rhesus 
menurut Fisher-Race dan Weiner ada pada Tabel 2.8. Penulisan Weiner jarang digunakan secara rutin, namun terkadang lebih mudah menggunakan 1 faktor daripada daftar alel individu pada terminologi Fisher-Race.

ISBT memiliki standarisasi nomenklatur sistem golongan darah. Enam digit angka telah ditetapkan untuk antigen spesifik setiap golongan darah. Tiga digit angka pertama mewakili sistem golongan darah, (misalnya: Rh, Lewis, Duffy, dll.). Sistem golongan darah Rhesus telah ditetapkan sebagai 004. Tiga angka dibelakangnya digunakan penomoran Rosenfield untuk antigen tersebut. Misalnya: nomor ISBT untuk antigen D adalah 004001. ISBT juga menunjuk sistem untuk menyediakan pengidentifikasi alfanumerik untuk setiap antigen. Pada sistem ini termasuk penulisan huruf kapital, diikuti oleh nomor spesifik antigen, seperti: $\mathrm{RH} 1$ mewakili antigen D. Ini dapat dilihat pada Tabel 2.9.

Tabel 2.8 Konversi antara Nomenklatur Fisher-Race dan Weiner

\begin{tabular}{|c|c|c|c|}
\hline \multicolumn{2}{|c|}{ FISHER-RACE } & \multicolumn{2}{|c|}{ WEINER } \\
\hline Gene & Antigens & Gene & Factors \\
\hline \multicolumn{4}{|c|}{ Combinations } \\
\hline $\mathrm{DCe}$ & $D, C, e$ & $\mathrm{R}^{1}$ & $\mathrm{Rh}_{\mathrm{o}}, \mathrm{rh}^{\prime}, \mathrm{hr} \mathrm{r}^{\prime \prime}$ \\
\hline DcE & $D, C, E$ & $\mathrm{R}^{2}$ & $\mathrm{Rh}_{\mathrm{o}}, \mathrm{hr}, \mathrm{rh}^{\prime \prime}$ \\
\hline Dce & $D, c, e$ & $\mathrm{R}^{\circ}$ & $\mathrm{Rh}_{\mathrm{o}}, \mathrm{hr}, \mathrm{hr}$ \\
\hline DCE & $D, C, E$ & $\mathrm{Rz}$ & $\mathrm{Rh}_{0}, r h^{\prime}, \mathrm{rh}^{\prime \prime}$ \\
\hline dce & $c, e$ & $r$ & $h r^{\prime}, h r^{\prime \prime}$ \\
\hline $\mathrm{dCe}$ & $C, e$ & $r^{\prime}$ & rh', hr" \\
\hline dcE & $c, E$ & $r^{\prime \prime}$ & $h r^{\prime}, r h^{\prime \prime}$ \\
\hline $\mathrm{dCE}$ & $C, E$ & ry & $r h^{\prime}, r h^{\prime \prime}$ \\
\hline
\end{tabular}

(Whitlock, 2010)

\section{Antigen D}


Dalam sistem Rhesus, antigen D merupakan antigen primer. Ketika antigen D ada pada eritrosit, maka individu tersebut mempunyai "Rh positif". Seseorang dapat mewarisi satu gen D dari setiap orangtua. Warisan salah satu atau dua gen D akan menunjukkanindividu tersebut sebagai "Rh positif". Jumlah individu dengan Rh positif mencapai $85 \%$ pada populasi di Kaukasia, dan $92 \%$ pada populasi Afrika-Amerika. Namun apabila tidak ada gen D yang diwarisi dari salah satu orangtua, maka individu tersebut disebut "Rh negatif". Individu Rh negatif jumlahnya sekitar $15 \%$ pada populasi Kaukasia, dan $8 \%$ pada populasi di Afrika-Amerika.

Antigen D bersifat sangat antigenik. Terdapat lebih dari $80 \%$ individu Rh negatif ( $D$ negatif) yang mendapatkan transfusi darah $\mathrm{Rh}$ positifakan menghasilkan anti-D pada paparan awal. Individu dengan $\mathrm{Rh}$ positif dapat menerima transfusi dengan darah $\mathrm{Rh}$ positif atau $\mathrm{Rh}$ negatif. Namun, individu dengan Rh negatif harus selalu menerima transfusi dengan darah Rh negatif kecuali jika situasinya mengancam jiwa dan hanya darah Rh positif yang tersedia. Transfusidarah Rh negatif sangat penting bagi wanita usia subur. Wanita Rh negatif yang menghasilkan anti-D cenderung menyebabkan Penyakit Hemolitik Janin dan Bayi Baru Lahir (HDFN) jika bayi dengan Rh positif lahir dari ibu Rh negatif.

Tabel 2.9 Ringkasan Nomenklatur untuk Sistem Golongan Darah Rh

\begin{tabular}{llll}
\hline NUMERIC & FISHER-RACE & WIENER & ISBT NUMBER \\
\hline Rh:1 & D & $\mathrm{Rh}_{0}$ & 004001 \\
Rh:2 & $\mathrm{C}$ & $\mathrm{Rh}^{\prime}$ & 004002 \\
$\mathrm{Rh}: 3$ & $\mathrm{E}$ & $\mathrm{Rh}^{\prime \prime}$ & 004003 \\
$\mathrm{Rh}: 4$ & $\mathrm{C}$ & $\mathrm{hr}^{\prime}$ & 004004 \\
$\mathrm{Rh}: 5$ & $\mathrm{e}$ & $\mathrm{hr}^{\prime \prime}$ & 004005 \\
$\mathrm{Rh}: 6$ & $\mathrm{ce}$ & $\mathrm{hr}$ & 004006 \\
\hline
\end{tabular}




\begin{tabular}{llll}
\hline Rh:7 & Ce & $\mathrm{rh}_{\mathrm{i}}$ & 004007 \\
$\mathrm{Rh}: 8$ & $\mathrm{C}^{\mathrm{w}}$ & $\mathrm{rh}^{\mathrm{w} 1}$ & 004008 \\
$\mathrm{Rh}: 9$ & $\mathrm{C}^{\mathrm{x}}$ & $\mathrm{rh}^{\mathrm{x}}$ & 004009 \\
$\mathrm{Rh}: 10$ & $\mathrm{ce}^{\mathrm{s}}$ & $\mathrm{hr}^{\mathrm{v}}$ & 004010 \\
$\mathrm{Rh}: 12$ & $\mathrm{G}$ & $\mathrm{rh}^{\mathrm{G}}$ & 004012 \\
\hline
\end{tabular}

(Whitlock, 2010)

\section{E. Antigen CcEe}

Sistem Rh mempunyai banyak antigen tambahan. Yang paling signifikan ialah dua pasang alel, yaitu: Cc dan Ee. Antigen tambahan mungkin ada pada lokus ini. Antigen-antigen ini jarang ditemukan, namun dapat memproduksi antibodi atipikal ketika ditransfusikan pada individu antigen-negatif.

\section{F. Antigen G}

Antigen $G$ adalah antigen yang ada pada setiap eritrosit, dimana ditemukan antigen $\mathrm{C}$ atau D. Ini bukan komponen antigen. Baik antigen $C$ dan $D$ tidak harus diwariskan agar antigen $G$ dapat hadir.Anti-G dapat ditemukan pada individu yang memiliki salah satu antigen ini. Karenanya, antibodi yang terbentuk akan tampak reaktif dengan kedua antigen $C$ dan $D$, bahkan jika hanya satu antigen yang ada pada eritrosit, misalnya: individu Rh positif yang tampak memiliki anti-D. Anti-G harus dibedakan dari anti-C dan anti-D dengan pengujian metode adsorpsi dan elusi.

\section{G. Antigen Rh yang Tidak Terdeteksi}

(1) Fenotip $\mathbf{R h}_{\text {null }}$

$\mathrm{Rh}_{\text {null }}$ sangat jarang ditemukan. Individu dengan $\mathrm{Rh}_{\text {null }}$ pada permukaan eritrositnya terjadi kekurangan total antigen Rh. Eritrosit $\mathrm{Rh}_{\text {null }}$ ini juga kekurangan Fy dan LW, yang merupakan antigen dengan frekuensi tinggi dan menunjukkan ekspresi 
antigen $\mathrm{S} / \mathrm{s}$ dan antigen $\mathrm{U}$ yang melemah. Penyebab fenotip $R \mathrm{~h}_{\text {null }}$ paling umum adalah karena adanya mutasi pada gen RHAG. Gen ini diperlukan untuk ekspresi antigen Rh pada eritrosit. Mutasi pada gen RHAG akan mempengaruhi ekspresi semua antigen Rh.

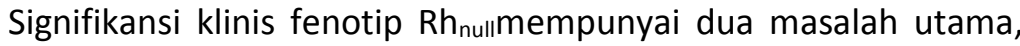
yaitu:

- Kesulitan menemukan darah yang cocok untuk individu $\mathrm{Rh}_{\text {null }}$ yang mempunyai banyak antibodi yang kompleks.

- Menurunnya masa hidup eritrosit karena membran eritrosit yang abnormal. Sehingga menyebabkan meningkatnya fragilitas osmotik, waktu paruh yang pendek, dan anemia hemolitik ringan.

\section{(2) Fenotip $R h_{\text {mod }}$}

Fenotip $\mathrm{Rh}_{\text {mod }}$ mirip dengan $\mathrm{Rh}_{\text {null, }}, \mathrm{Rh}$ mod memiliki jumlah antigen $\mathrm{Rh}$ yang menurun dalam jumlah besar, sedangkan $\mathrm{Rh}_{\text {null }}$ sepenuhnya hilang. Sel-sel mengalami penurunan jumlah antigen RHAG dan ekspresi antigen Rh hanya dapat dideteksi oleh metode

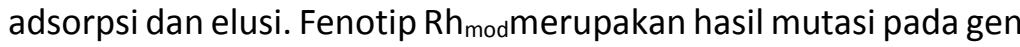
RHAG. Individu ini jugadapat menderita anemia hemolitik karena rusaknya membran eritrosit.

\section{H. Antibodi Rh}

Bila dibandingkan dengan sistem $A B O$, individu yang kekurangan antigen $\mathrm{Rh}$ jarang menghasilkan antibodi terhadap antigen tersebut tanpa stimulasi dari eritrosit melalui kehamilan atau transfusi. Antibodi terhadap semua antigen Rh dapat menyebabkan HDFN dan Reaksi Transfusi Hemolitik (HTR). Karakteristik semua antibodi Rhsama, terlepas dari antigen yang sesuai. Antibodi Rh merupakan antibodi IgG yang mengikat masing-masing antigen pada suhu $37^{\circ} \mathrm{C}$. Antibodi ini dapat menimbulkan aglutinasi pada $37^{\circ} \mathrm{C}$ dan 
dalam fase pengujian AHG. Mereka tidak mengikat komplemen dan diperbanyak oleh enzim. Karakteristik antibodi dalam golongan darah Rh ada pada Tabel 2.10.

\section{Signifikansi Klinis Antibodi Rh}

Antigen Rh bersifat sangat imunogenik, dan sebagian besar merupakan penyebab terjadinya reaksi transfusi hemolitik dan HDN. Walaupun sebagian besar golongan darah ditentukan oleh antigen eritrosit yang berbeda dengan satu atau dua asam amino, golongan darah $\mathrm{Rh}$ mengandung antigen $\mathrm{D}$ yang berbeda dari antigen $\mathrm{C} / \mathrm{c}$ dan E/e dengan 35 asam amino. Perbedaan jumlah asam amino yang besar inilah yang menyebabkan antigen Rh mempunyai kemampuan kuat dalam merangsang suatu respon imun. Mayoritas antibodi yang dibentuk terhadap antigen Rh merupakan jenis IgG, yang mampu menyebabkan HTR dan HDN yang signifikan. Antibodi Rh jarang, jika ada, mengikat komplemen, dan karenanya destruksi eritrosit diperantai hampir secara eksklusif oleh makrofag di limpa (hemolisis ekstravaskular). Ada beberapa contoh aloantibodi Rh yang terjadi secara alami dan dari tipe IgM, namun itu merupakan minoritas.

Tabel 2.10 Karakteristik Antibodi dalam Sistem Golongan Darah Rh

\begin{tabular}{ll}
\hline Immunoglobulin Class & IgG \\
Optimal Temperature of Reactivity & $37^{\circ} \mathrm{C}$ \\
Optimal Media of Reactivity & AHG \\
Effect of Enzymes & Enhanced \\
Display dosage & Yes \\
Capable of crossing the placenta & Yes \\
Capable of causing HDFN & Yes \\
Capable of causing HTR & Yes \\
\hline (Whitlock, 2010) &
\end{tabular}




\section{GOLONGAN DARAH LAIN}

Golongan darah $\mathrm{ABO}$ dan Rh merupakan sistem golongan darah yang paling signifikan secara klinis dan paling dikenal, namun terdapat sekitar 31 sistem lain yang memiliki relevansi klinis dan biologis yang beragam. Selain itu juga ada antigen lainnya yang belum ditentukan menjadi suatu sistem, baik yang frekuensinya sangat tinggi maupun sangat rendah.

\subsection{GOLONGAN DARAH LEWIS}

Sistem golongan darah Lewis memiliki 2 antigen utama, yaitu $\operatorname{Le}^{a}$ dan Le ${ }^{b}$. Antigen ini unik karena berbeda dengan kebanyakan sistem golongan darah, seperti $\mathrm{ABO}$ dan $\mathrm{Rh}$, antigen Lewis bukan bagian integral dari membran eritrosit. Antigen ini terbentuk dari sekresi dan diadsorpsi ke permukaan eritrosit. Bayi baru lahir tidak memiliki antigen Lewis dengan tipe Le(a-b-). Antigen mulai berkembang satu minggu setelah kelahiran, dan terus berkembang sampai dengan 6 tahun. Perkembangan dari antigen ini mulai dari Lewis $(a-b-) \rightarrow$ Lewis $(a+b-) \rightarrow$ Lewis $(a+b+) \rightarrow$ Lewis (a-b+). Tipe antigen akhir ini tidak akan terlihat sampai dengan usia sekitar enam tahun. Frekuensi antigen Lewis ada pada Tabel 2.11 .

Perkembangan antigen Lewis melibatkan interaksi 3 set gen. Gen-gen ini adalah $\mathrm{H}$, Secretor (Se), dan Lewis (Le). Produk dari gen $\mathrm{Le}, \mathrm{Se}$, dan $\mathrm{H}$ adalah glycotransferases. Varian amorf dari gen-gen ini (le, se, dan h) tidak menghasilkan produk yang terdeteksi. Interaksi gen ini terjadi sebagai berikut:

1. Kode gen Le untuk glycotransferase yang menghasilkan antigen Lea. Lea awalnya ada di cairan sekresi dan menjadi teradsorpsi ke permukaan eritrosit. Ini terjadi terlepas dari status sekretor. 2. Gen Se mengkode agar $\mathrm{H}$ transferase terdapat dalam cairan 
sekresi.

3. Ketika kombinasi Le, $\mathrm{H}$, dan Se ada bersama, Le glycotransferase akan menyembunyikan antigen $\mathrm{H}$ yang tersedia untuk Leb. Leb akan diadsorpsi ke dalam eritrosit, bukan Lea.

4. Kombinasi gen dan fenotip yang dihasilkan ditunjukkan pada Tabel 2.12

Tabel 2.11 Frekuensi Antigen Sistem Golongan Darah Lewis

\begin{tabular}{lll}
\hline Fenotip & $\begin{array}{l}\text { Frekuensi pada orang } \\
\text { Kaukasian }\end{array}$ & Kulit hitam \\
\hline Le $(a+b-)$ & 22 & 23 \\
Le(a-b+) & 72 & 55 \\
Le(a-b-) & 6 & 22 \\
\hline
\end{tabular}

(Whitlock, 2010)

Tabel 2.12 Gen Lewis, Sekretor, dan H dan Produknya yang Terdeteksi

\begin{tabular}{lll}
\hline Kombinasi Gen & Fenotip & Sekresi Antigen \\
\hline lele sese hh & Le $(a-b-)$ & None \\
Le sese hh & Le $(a+b-)$ & None \\
lele sese H & Le $(a-b-)$ & None \\
lele Se hh & Le $(a-b-)$ & None \\
Le sese H & Le $(a+b-)$ & Le $^{a}$ \\
lele Se H & Le $(a-b-)$ & $H$ \\
Le Se hh & Le $(a+b-)$ & Le $^{a}$ \\
Le Se H & Le $(a-b+)$ & Le $^{a}$ Le $^{b} H$ \\
\hline
\end{tabular}

(Whitlock, 2010) 


\subsection{GOLONGAN DARAH KELL}

Golongan darah Kell memiliki antigen yang dinamakan $\mathrm{K}$ atau KEL1, ini merupakan antigen original dari sistem Kell dan antigen golongan darah pertama yang diidentifikasi setelah penemuan uji antiglobulin pada tahun 1946. Kini sistem Kell terdiri dari 35 antigen yang diberi nomor dari KEL1 - KEL38, dengan 3 obsolete (tidak terpakai). Enam pasang dan satu triplet dari antigen antithesis Kell ada pada Tabel 2.13.

Sistem golongan darah Kell kompleks dan mengandung banyak antigen yang sangat imunogenik. Antigen ini merupakan yang paling kuat ketiga setelah golongan darah $\mathrm{ABO}$ dan Rh dalam mencetuskan terjadinya reaksi imunitas tubuh. Antibodi yang menargetkan antigen Kell dapat menyebabkan reaksi transfusi dan penyakit hemolitik pada bayi baru lahir (HDN). Dalam kasus HDN, inkompatibilitas $\mathrm{ABO}$ dan $\mathrm{Rh}$ merupakan penyebab yang lebih umum. Namun, penyakit yang disebabkan oleh anti-ABO ibu cenderung ringan, dan penyakit yang disebabkan oleh anti-Rh ibu sebagian besardapat dicegah. Jarang ditemukannya kasus HDN yang disebabkan oleh imunisasi Kell cenderung mengakibatkan anemia pada janin yang parah karena prekursor eritrosit janin merupakan target anti-Kell ibu, sehingga menekan produksi eritrosit janin. 


\section{A. Sejarah Golongan Darah Kell}

Sistem golongan darah Kell ditemukan pada tahun 1946. Namanya berasal dari Nyonya Kelleher, seorang pasien yang memiliki antibodi anti-Kell dan mengakibatkan penyakit hemolitik pada anaknya yang baru lahir (anak tersebut memiliki eritrosit dengan antigen $\mathrm{K}$ yang diikat oleh anti-K pada serum ibu). Hingga saat ini, diketahui terdapat total 25 antigen Kell yang ditemukan dan memiliki frekuensi yang berbeda pada populasi yang berbeda. Namun antigen $\mathrm{K}$ original tetap sangat penting dalam transfusi darah dan HDN.

Tabel 2.13 Antigen Antitesis dari Sistem Golongan Darah Kell

\begin{tabular}{|c|c|c|c|c|c|}
\hline \multicolumn{2}{|c|}{ High } & \multicolumn{2}{|c|}{ Low } & \multirow{2}{*}{$\begin{array}{l}\text { Molecular } \\
\text { basis } \\
\text { Thr193Met }\end{array}$} & \multirow{2}{*}{$\begin{array}{l}\text { Molecular basis } \\
\text { Caucasians, Africans }\end{array}$} \\
\hline $\mathrm{k}$ & KEL2 & $\mathrm{K}$ & KEL1 & & \\
\hline \multirow[t]{2}{*}{$K p^{b}$} & KEL4 & $\mathrm{Kp}^{\mathrm{a}}$ & KEL3 & Arg281Trp & Caucasians \\
\hline & & $\mathrm{Kp} \mathrm{p}^{\mathrm{c}}$ & KEL21 & Arg281GIn & Not polymorphic \\
\hline$J s^{b}$ & KEL7 & $\mathrm{JS}^{\mathrm{a}}$ & KEL6 & Leu597Pro & Africans \\
\hline K11 & KEL11 & K17 & KEL17 & Val302Ala & Not polymorphic \\
\hline K14 & KEL14 & K24 & KEL24 & Arg180Pro & Not polymorphic \\
\hline \multirow{2}{*}{\multicolumn{2}{|c|}{ Not identified }} & VLAN & KEL25 & Arg248GIn & Not polymorphic \\
\hline & & VONG & KEL28 & Arg248Trp & \\
\hline KYOR & KEL38 & KYO & KEL31 & Arg292Glu & Japanese \\
\hline
\end{tabular}

(Daniels \& Bromilow, 2014)

\section{B. Antigen Kell}

Antigen sistem Kell terletak pada glikoprotein membran eritrosit yaitu $\mathrm{N}$-glycosylated.Kell merupakan sistem kompleks yang sampai saat ini terdiri dari 24 antigen. Terdapat 5 set alel yang mengekspresikan antigen dengan frekuensi tinggi dan rendah serta sekitar 14 antigen independen lainnya. Pada Tabel 2.12 dapat dilihat fenotip dan frekuensi sistem Kell secara umum. Antigen Kell antigen menunjukkan variasi pada populasi yang berbeda. Antigen $\mathrm{K}$ terjadi 
pada $9 \%$ kulit putih tetapi hanya $2 \%$ kulit hitam. Antigen $\mathrm{Kp}^{\mathrm{a}}$ memiliki frekuensi $2 \%$ pada orang kulit putih namun jarang pada orang kulit hitam. Terdapat Antigen $\mathrm{Kp}^{\mathrm{c}} 0,2 \%$ di Jepang dan jarang pada antigen lain. Antigen $\mathrm{Js}^{\mathrm{a}}$ dapat terjadi pada $20 \%$ orang kulit hitam tetapi jarang pada orang kulit putih. Antigen $\mathrm{Ul}^{\mathrm{a}}$ adalah antigen dengan frekuensi rendah, tetapi ditemukan pada $2,6 \%$ orang Finlandia dan $0,46 \%$ orang Jepang. Antigen lainnya merupakan insiden tinggi atau rendah. Antigen Ku mewakili antigen "total Kell" dan individu yang kekurangan Ku dianggap $K_{\text {null. }}$

\section{Antibodi Kell}

Antigen $\mathrm{K}$ merupakan antigen golongan darah paling imunogenik setelah $A B O$ dan $R h$, yang menyebabkan penyakit hemolitik pada bayi baru lahir dan HTRs segera dan tertunda. Antibodi umumnya IgG, terutama IgG1. Pasien dengan antibodi terhadap sistem golongan darah Kell harus menerima darah antigennegatif.

Adanya anti-K tampaknya tidak seberapa parah dalam kasus HDFN dibandingkan anti-D. Antigen $\mathrm{K}$ muncul pada eritrosit janin lebih awal daripada protein Rh. Akibatnya, anti-K memfasilitasi fagositosis pada tahap lebih awal, sebelum sel menghasilkan hemoglobin. Anemia parah dapat terjadi karena anti-K menyebabkan penekanan eritropoiesis daripada mendestruksi imunitas dengan anti-D.

Antibodi terhadap $\mathrm{Kp}^{\mathrm{a}}, \mathrm{Kp}^{\mathrm{b}}, \mathrm{Kp}^{\mathrm{c}}$, Js ${ }^{\mathrm{a}}$, dan $\mathrm{Js}^{\mathrm{b}}$ juga ditemukan dan dalam kasus HDFN dan HTR. Ras harus dipertimbangkan ketika mengidentifikasi antibodi. Antigen Kpahanya ditemukan pada ras kulit putih dan $\mathrm{Kp}^{\mathrm{c}}$ hanya ditemukan pada orang Asia. Baik $\mathrm{Kp}^{\mathrm{a}}$ dan $\mathrm{Kp}^{\mathrm{c}}$ merupakan antigen dengan insiden rendah, sehingga mayoritas individu adalah $\mathrm{Kp}(\mathrm{a}-\mathrm{b}+\mathrm{c}-)$. Antigen $\mathrm{Js}^{\mathrm{a}}$ lebih umum pada orang kulit 
hitam sedangkan antigen $\mathrm{Kp}^{\mathrm{a}}$ pada orang kulit putih atau $\mathrm{Kp}^{\mathrm{c}}$ pada orang Asia.

Individu yang kekurangan antigen Kell yang diimunisasi untuk menghasilkan antibodi yang disebut anti-Ku (K untuk Kell dan u untuk universal). Selain itu, serum mereka mungkin mengandung antibodi untuk antigen Kell dengan insiden tinggi lainnya.

\subsection{GOLONGAN DARAH DUFFY}

Glikoprotein Duffy merupakan reseptor untuk bahan kimia yang disekresikan oleh sel darah selama inflamasi, serta reseptor untuk Plasmodium vivax, yaitu parasit yang menyerang eritrosit dan menyebabkan malaria. Eritrosit yang tidak memiliki antigen Duffy relatif resisten terhadap invasi oleh $P$. vivax. Ini mempengaruhi variasi golongan darah Duffy yang tampak pada populasi dimana malaria umum terjadi. Antibodi yang terbentuk melawan antigen Duffy merupakan penyebab dari reaksi transfusi dan penyakit hemolitik pada bayi baru lahir.

\section{A. Sejarah Golongan Darah Duffy}

Golongan darah Duffy ditemukan pada tahun 1950. Nama Duffy berasal dari Tn. Duffy, nama pasien hemofilia yang telah menerima banyak transfusi darah, dan orang pertama yang diketahui menghasilkan anti-Fy ${ }^{\mathrm{a}}$. Setahun kemudian, anti-Fy ${ }^{\mathrm{b}}$ ditemukan pada seorang wanita yang memiliki beberapa anak. Antigen Duffy yang tersisa (FY3, FY4, FY5, dan FY6) ditemukan 20 tahun kemudian, dan hanya FY3 yang tampak signifikan secara klinis.

Frekuensi fenotip Duffy bervariasi dalam populasi yang berbeda. Fenotip Duffy null, Fy (ab-), jarang ditemukan pada populasi Kaukasia dan Asia, namun paling umum di ditemukan pada kulit hitam,terjadi pada lebih dari $2 / 3$ populasi kulit hitam. Variasi rasial 
dalam distribusi antigen Duffy merupakan hasil dari tekanan seleksi positif, dimana tidak adanya antigen Duffy pada eritrosit menyebabkan ertirosit lebih tahan terhadap invasi oleh parasit malaria.

Terdapat 4 jenis spesies Plasmodium sebagai penyebab malaria pada manusia, $P$. falciparum dapat menyebabkan sebagian besar kasus yang berakibat fatal. Namun di Asia dan Amerika, malaria umumnya disebabkan oleh $P$. vivax. Untuk menyebabkan penyakit, $P$. vivax harus memasukkan eritrosit manusia dengan cara mengikat domain ekstraseluler $\mathrm{N}$-terminal glikoprotein Duffy melalui region rich sistein dari Duffy binding protein (DBP). Individu dengan fenotip Duffy null tidak mengekspresikan protein Duffy pada eritrosit mereka sehingga kebal terhadap infeksi $P$. vivax. Menariknya, fenotip Fy (ab-) umumnya terdapat di daerah dengan sedikit kasus malaria $P$. vivax. Di Afrika Barat, terdapat frekuensi tinggi fenotip Fy (a-b-) dan rendahnya insiden malaria akibat $P$. vivax. Ini disebabkan karena praeksistensi frekuensi tinggi fenotip Fy (a-b-) mencegah malaria $P$. vivax menjadi endemik di Afrika Barat.

\section{B. Antigen Duffy}

Antigen Duffy merupakan glikoprotein dan bagian integral dari membran eritrosit. Glikoprotein inijuga diekspresikan pada sel non erythroid termasuk endotelium, otak, usus besar, paru-paru, limpa, ginjal, tiroid,dan timus. Glikoprotein terkait dengan family reseptor IL-8 dan berfungsi sebagai reseptor eritrosit untuk kemokin proinflamasi. Kemokin berperan utama dalam inflamasi serta infeksi malaria. Antigen Duffy berfungsi sebagai anggota superfamily reseptor kemokin serta reseptor untuk parasit malaria manusia, yaitu Plasmodium vivax.

Glikoprotein Duffy terdiri dari 7 domain spanning transmembran dengan intraseluler dan loop ekstraseluler. 
Glikoprotein memiliki domain terminal $\mathrm{N}$ eksoseluler dan domain terminal $\mathrm{C}$ endoseluler. Dua antigen utama, yaitu $\mathrm{Fy}^{\mathrm{a}}$ dan $\mathrm{Fy}^{\mathrm{b}}$, diwariskan sesuai metode Mendel dan dibedakan oleh single kodon. Ada 3 genotip yang mungkin, antara lain: $\mathrm{Fy}^{\mathrm{a}} \mathrm{Fy}^{\mathrm{a}}, \mathrm{Fy}^{\mathrm{a}}$ $\mathrm{Fy}^{\mathrm{b}}$, dan $\mathrm{Fy}^{\mathrm{b}} \mathrm{Fy}^{\mathrm{b}}$. Frekuensi fenotip ada pada Tabel 2.14. Terdapat frekuensi fenotip yang berbeda antara populasi Kaukasia dan kulit hitam.

Tabel 2.14 Persentase Frekuensi Fenotip dari Antigen Duffy

\begin{tabular}{lll}
\hline Fenotip & Kaukasian & Kulit Hitam \\
\hline Fy(a+b-) & 17 & 9 \\
Fy(a-b+) & 34 & 22 \\
Fy $(a+b+)$ & 49 & 1 \\
Fy $(a-b-)$ & Jarang & $>68$ \\
\hline
\end{tabular}

(Whitlock, 2010)

\section{Antibodi Duffy}

Karakteristik antibodi ini merupakan IgG, AHG antibodi reaktif yang telah distimulasi secara aktif melalui paparan antigen langsung. Antibodi Duffy berupa IgG dan mampu menyebabkan Penyakit Hemolitik Janin dan Bayi Baru Lahir dan reaksi transfusi hemolitik. 


\subsection{GOLONGAN DARAH KIDD}

Glikoprotein Kidd (JK) merupakan transporter urea eritrosit. Terletak di membran eritrosit untukmengangkut urea secara cepat ke dalam dan keluar eritrosit, menjaga stabilitas osmotik dan proses pembentukan eritrosit. Glikoprotein Kidd juga diekspresikan dalam ginjal, sehingga memungkinkan ginjal untuk memenuhi kebutuhan urea yang tinggi yang diperlukan untuk menghasilkan urin pekat. Orang-orang yang tidak memproduksi glikoprotein Kidd cenderung tidak mampu untuk memekatkan urin secara maksimal, namun mereka sehat dan eritrositnya memiliki bentuk dan masa hidup normal.

Antibodi dengan target antigen Kidd merupakan penyebab signifikan dari reaksi transfusi hemolitik yang tertunda. Antibodi anti-Kidd juga merupakan penyebab penyakit hemolitik pada bayi baru lahir (HDN), tingkat keparahan penyakit bervariasi namun cenderung bersifat ringan.

\section{A. Sejarah Golongan Darah Kidd}

Pada tahun 1951, seorang pasien bernama Nyonya Kidd diketahui memproduksi antibodi yang melawan antigen eritrosit yang tidak diketahui selama kehamilannya. Sehingga antibodi ibu tersebut menyebabkan penyakit hemolitik yang fatal pada bayinya yang baru lahir. Protein itu diberi nama $\mathrm{Jk}^{\mathrm{a}}$ dan merupakan antigen pertama yang ditemukan dalam sistem golongan darah Kidd. Sejak itu, dua antigen lain yaitu $\mathrm{Jk}^{\mathrm{b}}$ dan $\mathrm{Jk3}$ juga ditemukan. Pada tahun 1959, contoh pertama dari fenotipe nol, yaitu, Jk(a-b-) ditemukan pada seorang wanita mengalami jaundice (penyakit kuning) setelah 
transfusi darah. Serumnya ditemukan mengandung antibodi yang mengenali $\mathrm{Jk}^{\mathrm{a}}$ dan $\mathrm{Jk}^{\mathrm{b}}$. Antibodi ini kemudian dinamakani anti-Jk3.

\section{B. Antigen dan Antibodi Kidd}

Antigen $\mathrm{Jk}^{\mathrm{a}}$ dan $\mathrm{Jk}^{\mathrm{b}}$ bertanggungjawab terhadap kesamaan fenotip. Fenotip dan frekuensi golongan darah Kidd ada pada Tabel 2.15 .

Pembentukan antibodi Kidd distimulasi oleh kehamilan dan transfusi darah, meskipun antibodi ini tidak terlalu bersifat imunogenik. Anti-Jk ${ }^{\mathrm{a}}$ sering ditemukan dengan spesifisitas lain, namun anti-Jk ${ }^{\mathrm{b}}$ umummnya ditemukan dengan antibodi lain. Keduanya bereaksi lemah karena merupakan antibodi IgG yang kadarnya sedikit dalam darah. Reaktivitas dapat ditingkatkan dengan enzim. Antibodi Kidd dikenal melemah dari waktu ke waktu dan bahkan menjadi tidak terdeteksi. Antibodi kemungkinan tidak ditemukan pada saat dilakukan pengujian pretransfusi darah.

Meskipun demikian, antibodi ini dapat mengakibatkan HTR tertunda yang parah. Pasien yang membutuhkan transfusi harus menerima darah antigen negatif. Anti-Jk ${ }^{\mathrm{a}}$, anti-Jk ${ }^{\mathrm{b}}$, dan anti-Jk3 dapat menyebabkan HDN, tetapi biasanya ringan walaupun merupakan IgG, mengikat komplemen, dan antigennya berkembang dengan baik pada sel-sel janin.

Tabel 2.15. Fenotip dan Frekuensi Golongan Darah Kidd

\begin{tabular}{llll}
\hline Fenotip & \multicolumn{3}{c}{ Frekuensi (\%) } \\
& Kulit Putih & Kulit Hitam & Asia \\
\hline Jk(a+b-) & 26,3 & 51,1 & 23,2 \\
$J k(a-b+)$ & 23,4 & 8,1 & 26,8 \\
$J k(a+b+)$ & 50,3 & 40,8 & 49,1 \\
\hline
\end{tabular}




\begin{tabular}{|c|c|c|c|}
\hline$J k(a-b-)$ & Jarang & Jarang & 0,9 (polinesia) \\
\hline
\end{tabular}

(Quinley, 2011)

\subsection{GOLONGAN DARAH MNS}

Antigen golongan darah MNS, membawa protein yang mengandung gula yang disebut glikophorin. Ini terletak di membran eritrosit. Salah satu ujung glikophorin melekat pada sel di bawahnya, dan ujung yang lain menahan gula dan menentukan tipe golongan darah MNS seseorang.

\section{A. Antigen Golongan Darah MNS}

Sistem Golongan Darah MNS terdiri dari lebih dari 40 antigen. Yang paling umum antara lain: $\mathrm{M}, \mathrm{N}, \mathrm{S}, \mathrm{s}$, dan U. Frekuensi antigen MNS ada pada Tabel 2.16. Dua gen yang mengkode pasangan gen, $\mathrm{M} / \mathrm{N}$ dan $\mathrm{S} / \mathrm{s}$, terletak pada kromosom 4 . Terdiri dari 2 gen, yaitu GYPA dan GYPB, kode untuk glikophorin A (GPA) dan glikophorin B (GPB). Kode GPA untuk antigen M dan N, dan kode GPB untuk antigen $S$ dan s. Gen-gen itu terletak berdekatan dan diwariskan sebagai haplotype daripada independen. Kemungkinan haplotypes adalah Ms, MS, Ns, dan NS. Haplotype yang paling sering diwariskan adalah Ns. Mewarisi $\mathrm{M}$ atau $\mathrm{N}$ dalam keadaan homozigot meningkatkan kekuatan ekspresi antigenik.

\section{B. Antibodi Golongan Darah MNS}

Antibodi terhadap antigen $\mathrm{MN}$ paling sering merupakan antibodi yang bereaksi pada suhu dingin dari jenis IgM. Antibodi ini dapat terjadi secara non-stimulasi eritrosit maupun distimulasi oleh paparan (exposure). Anti-M umumnya berupa antibodi yang secara klinis tidak signifikan dan jarang terlibat dalam HDFN. Anti-N miliki 
karakteristik yang identik dengan anti-M. Ditemukan lebih jarang daripada anti-M. Antibodi anti-M dan anti-N bersifat non-reaktif dalam enzim. Sebaliknya, antibodi terhadap antigen Ss dan $U$ paling sering bereaksi pada suhu $37^{\circ} \mathrm{C}$ dan pada fase pengujian AHG. Antibodi ini berupa IgG yang secara klinis signifikan dan dapat menyebabkan HDFN dan menurunkan kelangsungan hidup eritrosit. Sedangkan anti-U jarang ditemukan. Karakteristik antibodi MN ada pada Tabel 2.17.

Tabel 2.16 Frekuensi Antigen Golongan Darah MNS pada Dewasa

\begin{tabular}{lll}
\hline Antigen & $\begin{array}{l}\text { Frekuensi (\%) } \\
\text { Kulit Putih }\end{array}$ & Kulit Hitam \\
\hline M & 78 & 74 \\
$\mathrm{~N}$ & 72 & 75 \\
$\mathrm{~S}$ & 55 & 31 \\
$\mathrm{~S}$ & 89 & 94 \\
$\mathrm{U}$ & 99,9 & 99 \\
\hline
\end{tabular}

(Whitlock, 2010)

Tabel 2.17 Karakteristik Antibodi MN

\begin{tabular}{lllll}
\hline Simbol & No. ISBT & Kelas & Signifikansi klinis \\
& & WHO & & \\
\hline MNS1 & 002 & IgM, IgG & Tidak menyebabkan & HDFN \\
(Anti-M) & & (jarang) & atau HTR & \\
MNS2 & 002 & IgM, IgG & Tidak menyebabkan & HDFN \\
(Anti-N) & & (jarang) & atau HTR & \\
\hline
\end{tabular}

(Whitlock, 2010) 


\section{RANGKUMAN :}

- Sistem golongan darah dan antibodi merupakan dasar untuk pemeriksaan pra transfusi darah.

- Sistem $A B O$ paling penting dalam bidang transfusi, karena transfusi sistem $A B O$ yang inkompatibel akan mengakibatkan gejala reaksi transfusi hemolitik dan mengakibatkan koagulasi intravaskular diseminata, gagal ginjal, dan kematian.

- Antigen $A B O$ terletak di permukaan eritrosit. Antigen ABO juga ditemukan pada limfosit, trombosit, organ, sel endotel, dan sel epitel.

- Individu $\mathrm{O}_{\mathrm{h}}$ Bombay mempunyai antibodi anti-H, anti-A dan anti$B$ yang kuat di dalam serumnya. Sehingga mereka hanya bisa menerima transfusi hanya dengan golongan darah $\mathrm{O}_{\mathrm{h}}$.

- Individu yang memiliki antigen $\mathrm{ABH}$ terlarut (SeSe atau Sese) dalam cairan sekresi tubuhnya disebut sekretor. Sedangkan individu yang tidak memiliki antigen A atau B di cairan sekresi tubuhnya (sese) disebut non sekretor.

- Sistem Rhesus telah menjadi golongan darah terpenting kedua setelah $A B O$ di bidang transfusi darah. Sistem Rhesus sangat penting dalam bidang obstetri, karena menjadi penyebab utama penyakit hemolitik pada bayi baru lahir atau Hemolytic Disease of the Newborn (HDN).

- Terdapat 33 sistem golongan darah lain selain ABO dan Rhesus yang memiliki relevansi klinis dan biologis yang beragam, 
diantara: golongan darah Lewis, Kell, Duffy, Kidd, MNS, dan sebagainya.

\section{LATIHAN SOAL :}


1. Sistem golongan darah yang paling penting dalam transplantasi dan transfusi karena bermakna klinis adalah
a. ABO dan Rhesus
b. ABO dan Lewis
c. Rhesus dan MNS
d. Rhesus dan Kell
e. ABO dan Duffy

2. Golongan darah yang sering disebut "donor universal" adalah
a. Golongan darah A
b. Golongan darah B
c. Golongan darah $\mathrm{O}$
d. Golongan darah $A B$
e. Golongan darah O Bombay

3. Golongan darah yang sering disebut "resipien universal" adalah
a. Golongan darah A
b. Golongan darah B
c. Golongan darah $\mathrm{O}$
d. Golongan darah AB
e. Golongan darah O Bombay

4. Golongan darah dengan ciri fenotip defisiensi-H disebut
a. Golongan darah A
b. Golongan darah B
c. Golongan darah $\mathrm{O}$
d. Golongan darah $A B$
e. Golongan darah O Bombay

5. Kemampuan seseorang untuk mensekresikan substansi terlarut dalam cairan tubuhnya sehingga substansi $A, B$ dan $H$ dapat 
ditemukan pada saliva, keringat, air mata, dan semen disebut
a. $\mathrm{O}_{\mathrm{h}}$ Bombay
b. Sekretor
c. Non sekretor
d. Sistem golongan darah $A B O$
e. Sistem golongan darah Rhesus

6. Pada kasus dimana individu golongan darah $A$ dapat memperoleh antigen $B$ dan menjadi golongan darah $A B$, dapat terjadi pada penyakit
a. Leukemia myeloid akut
b. Leukemia myeloid kronik
c. Kanker usus besar
d. Reaksi transfusi hemolitik
e. Koagulasi intravaskular diseminata

7. Individu dengan golongan darah A akan memiliki antibodi pada serumnya.
a. Anti-A
b. Anti-B
c. Anti-A dan Anti-B
d. Tidak memiliki anti-A dan Anti-B
e. Memiliki anti-H

8. Individu dengan golongan darah $\mathrm{O}$ akan memiliki antibodi pada serumnya.
a. Anti-A
b. Anti-B
c. Anti-A dan Anti-B
d. Tidak memiliki anti-A dan Anti-B
e. Memiliki anti-H

9. Sistem golongan darah yang merupakan penyebab utama penyakit hemolitik pada bayi baru lahir adalah 

a. $A B O$
b. Rhesus
c. Lewis
d. Kell
e. Duffy

10. Glikoprotein yang merupakan reseptor untuk bahan kimia yang disekresikan oleh sel darah selama inflamasi, serta reseptor untuk Plasmodium vivax adalah ..........
a. Golongan darah Lewis
b. Golongan darah Duffy
c. Golongan darah Kell
d. Golongan Darah Kidd
e. Golongan darah MNS 
$=$ 


\section{REFERENSI :}

Daniels, G., \& Bromilow, I. (2014). Essential Guide to Blood Groups.

Third Edition. West Sussex, UK: Wiley Blackwell.

Dean, L. (2005). Blood Groups and Red Cell Antigens. Bethesda (MD):

National Center for Biotechnology Information (US).

Maharani, E. A., \& Noviar, G. (2018). Imunohematologi dan Bank

Darah. Jakarta: Pusat Pendidikan Sumber Daya Manusia Kesehatan Kemenkes RI.

Mitra, R., Mishra, N., \& Rath, G. P. (2014). Blood groups systems. Indian journal of anaesthesia, 58(5), 524-528. https://doi.org/10.4103/0019-5049.144645

Motghare, P., Kale, L., Bedia, A. S., \&Charde, S. (2011). Efficacy and Accuracy of $A B O$ Blood Group Determination from Saliva. Journal of Indian Academy of Oral Medicine and Radiology,23(3), 163-167. Retrieved from https://pdfs.semanticscholar.org/8600/7ad158b254744506916 a9a9c66fe3991b334.pdf.

Quinley, E. D. (2011). Immunohematology Principles \& Practice. Third Edition. Philadelphia: Lippincott Williams \& Wilkins.

Smart, E., \& Armstrong, B. (2008). Blood Group System. Journal compilation ISBT Science Series, 3, 68-92. https://doi.org/10.1111/j.1751-2824.2008.00188.x

Whitlock, S. A. (2010). Immunohematology For Medical Laboratory Technicians. USA: Delmar, Cengage Learning. 


\section{BAB 3}

\section{SISTEM ADMINISTRASI DONOR DARAH}

\section{Sub - Capaian Pembelajaran Mata Kuliah :}

- Mampu memahami tentang jenis-jenis komponen darah beserta dengan fungsinya.

- Mampu menjelaskan tentang persyaratan atau kriteria donor dalam pengambilan darah.

- Mampu memahami mengenai macam transfusi darah alternatif beserta fungsinya.

\subsection{KOMPONEN DARAH}




\section{A. Darah Utuh (Whole Blood)}

Darah merupakan cairan kompleks terdiri dari sel-sel darah berbeda yang tersuspensi dalam cairan kekuningan yang disebut plasma. Sel darah terdiri dari sel darah merah (eritrosit), sel darah putih (leukosit), dan platelet (trombosit). Plasma darah mengandung beberapa protein, substansi kimia, faktor pembekuan (koagulasi) dan banyak substansi metabolisme. Darah berfungsi sebagai media transportasi untuk membawa semua komponen yang berbeda ke berbagai organ tubuh.

\section{B. Eritrosit}

Bentuk eritrosit tampak seperti cakram bikonkaf bila dilihat dibawah mikroskop. Eritrosit mempunyai diameter 7,2 mikron dan terdapat sekitar 5 juta sel eritrosit per $\mathrm{mm}^{3}$ darah $\left(5 \times 10^{12} / \mathrm{L}\right)$. Eritrosit diproduksi di sumsum tulang, kemudian memasuki aliran darah ketika sudah matur. Rata-rata masa hidup eritrosit adalah 120 hari, setelah itu eritrosit mengalami penuaan dan destruksi (menjadi rusak) serta dihancurkan oleh sel-sel dalam sistem reticulum endothelium. Sel-sel khusus ini tersebar diseluruh tubuh dan ditemukan terutama di sumsum tulang, hati, limpa, dan kelenjar getah bening. Eritrosit mengandung hemoglobin yang memiliki fungsi utama dalam membawa oksigen ke jaringan tubuh.

\section{Hemoglobin (Hb)}

Hemoglobin merupakan molekul besar kompleks terdiri dari molekul besi yaitu hem yang melekat pada rantai polipeptida yang disebut globin. Hemoglobin inilah yang menyebabkan eritrosit berwarna merah. Hemoglobin memiliki kemampuan untuk berikatan dengan oksigen dan karbon dioksida secara reversibel. Hemoglobin berfungsi mengangkut oksigen ke berbagai jaringan guna menyediakan energi dan panas bagi tubuh. Oksigen diambil dari 
paru-paru dan dipompa oleh jantung ke jaringan. Setelah digunakan, oksigen digantikan oleh karbon dioksida dan dibawa kembali ke paruparu oleh eritrosit dan sebagian kecil oleh plasma. Selanjutnya diganti dengan oksigen baru dan siap untuk memulai siklus sirkulasi berikutnya.

Kadar hemoglobin diukur dalam satuan gram hemoglobin per desiliter darah. Nilai normal hemoglobin pada pria sedikit lebih tinggi daripada wanita. Nilai normal hemoglobin pada pria yaitu $13,5-17,0$ $\mathrm{g} / \mathrm{dl}$ dan pada wanita yaitu 12,0 - 16,0 g/dl. Kadar hemoglobin minimum yang dapat diterima oleh pusat transfusi darah di banyak negara, yaitu: 13,5 g/dl pada pria, dan 12,5 g/dl pada wanita. Metode pemeriksaan hemoglobin terbaik adalah dengan menggunakan teknik kolorometrik atau fotometrik.

Kadar hemoglobin juga dapat dilakukan dengan teknik estimasi, dengan cara membandingkan berat jenis hemoglobin dengan berat jenis larutan tembaga sulfat yang telah diketahui kadarnya. Teknik ini dapat digunakan dalam praktik transfusi darah dan cocok diterapkan di daerah yang tidak tersedia listrik atau minimum pasokan listrik. Kadar hemoglobin donor yang dapat diterima ditentukan dengan mengkonfirmasi bahwa setetes darah dapat meresap dalam larutan tembaga sulfat dengan berat jenis 1,055 untuk pria dan 1,053 untuk wanita.

\section{Leukosit}

Leukosit merupakan sel yang memiliki inti yang terdiri dari granulosit dan agranulosit. Granulosit terdiri dari: neutrofil, eosinofil, dan basofil. Sedangkan agranulosit meliputi: limfosit dan monosit. Dalam kondisi normal, granulosit hanya berasal dari sumsum tulang. Sejumlah kecil limfosit diproduksi di sumsum tulang, tetapi pasokan utama berasal dari jaringan limfatik dan timus. Monosit kemungkinan diproduksi di area jaringan retikuloendotelial, terutama limpa. 
Jumlah normal leukosit yang bersirkulasi dalam darah jauh lebih sedikit daripada jumlah sel eritrosit. Nilai normal jumlah leukosit adalah 4000 - 11.000 leukosit per $\mathrm{mm}^{3}\left(4,0-11,0 \times 10^{9} / \mathrm{L}\right)$ darah, meliputi:

- Eosinofil: 0 - 400 per $\mathrm{mm}^{3}\left(0-0,4 \times 10^{9} / \mathrm{L}\right)$

- Basofil: 0 - 200 per $\mathrm{mm}^{3}$ (0 - 0,2 x 109/L)

- Neutrofil: 1500 - 7500 per $\mathrm{mm}^{3}\left(1,5-7,5 \times 10^{9} / \mathrm{L}\right)$

- Limfosit: $1000-4500$ per $\mathrm{mm}^{3}\left(1,0-4,5 \times 10^{9} / \mathrm{L}\right)$

- Monosit: 0 - 800 per $\mathrm{mm}^{3}\left(0-0,8 \times 10^{9} / \mathrm{L}\right)$

Leukosit memiliki umur lebih pendek daripada eritrosit. Masa hidup granulosit adalah sekitar 3-5 hari, dan berperan utama dalam melawan infeksi. Masa hidup limfosit mulai dari beberapa hari hingga bertahun-tahun. Limfosit berperan penting dalam memproduksi antibodi terhadap antigen asing dan melawan infeksi virus. Monosit meninggalkan sistem peredaran darah setelah beberapa hari, dan disebut scavenger cells karena dapat menelan bakteri dan benda asing lainnya melalui proses fagositosis.

\section{E. Trombosit (Platelet)}

Ukuran trombosit jauh lebih kecil daripada eritrosit dan leukosit. Nilai normal jumlah trombosit adalah 150.000 - 500.000 per $\mathrm{mm}^{3}$ (150 - $\left.500 \times 10^{9} / \mathrm{L}\right)$ darah pada orang dewasa normal. Trombosit berperan penting dalam mekanisme pembekuan darah. Trombosit melepaskan substansi di lokasi luka atau cedera dan bergabung dengan faktor pembekuan lain dalam plasma untuk menghasilkan benang protein halus (fibrin). Selanjutnya, fibrin membentuk jaring halus atau jaringan yang menjerat eritrosit untuk menghasilkan pembekuan dan mencegah pendarahan lebih lanjut. Penyimpanan trombosit dengan benar memiliki masa simpan laboratorium sampai dengan 5 hari sebelum dilakukan transfusi darah.

\section{F. Koagulasi Darah}


Pada saat darah yang ada dalam spuit dimasukkan ke dalam tabung maka akan terjadi koagulasi atau pembekuan darah, dimana terbentuk massa semi-solid sel darah. Cairan yang mengelilingi massa semi-solid ini dinamakan serum. Namun, jika darah dimasukkan ke dalam tabung yang berisi antikoagulan, yaitu suatu substansi yang mencegah pembekuan darah, maka sedimen sel yang tidak membeku ada di bagian bawah tabung. Cairan yang mengelilingi selsel yang tidak membeku ini disebut plasma.

Proses pembekuan darah sangat kompleks, terdiri dari jalur intrinsik (surface contact) dan ekstrinsik (cedera jaringan). Kerusakan atau cedera pada pembuluh darah akan memicu jalur koagulasi atau kaskade, menyebabkan perubahan dari fibrinogen terlarut menjadi fibrin, yang membentuk bekuan yang stabil dan mencegah perdarahan lebih lanjut.

\section{G. Tujuan Transfusi Darah}

Terdapat 3 tujuan utama transfusi darah, antara lain: untuk mengatasi anemia (penurunan kadar hemoglobin); untuk menggantikan kehilangan darah akibat perdarahan, baik karena operasi atau kecelakaan; dan untuk menggantikan komponen darah lainnya, misalnya faktor pembekuan.

\subsection{KRITERIA DONOR DALAM PENGAMBILAN DARAH}

Prosedur seleksi (screening) donor dalam beberapa tahun terakhir semakin berkembang. Prosedur terbaru mempertimbangkan beberapa komponen penting, diantaranya kesehatan pendonor, produk darah yang bebas dari transfusion transmissable diseases (TTD), dan perlindungan donor selama proses pengambilan darah dan pemulihan setelah pengambilan darah 
selesai. Proses screening donor meliputi tiga fase, yaitu: pendaftaran, wawancara riwayat kesehatan, dan pemeriksaan fisik.

\section{A. Registrasi Donor}

Registrasi donor diperlukan pada setiap kegiatan transfusi darah. Catatan registrasi donor meliputi dokumentasi yang sepenuhnya mengidentifikasi donor, dan identifikasi harus diverifikasi oleh setiap pendonor. Sistem komputerisasi dapat digunakan dalam proses registrasi pendonor untuk memudahkan memperbarui informasi yang diperlukan. Informasi penting dalam registrasi pendonor, antara lain:

- Tanggal dan waktu donasi

- Nama lengkap

- Alamat rumah dan atau kantor

- Telepon rumah dan atau kantor

- Jenis kelamin

- Umur atau tanggal lahir

- Rekaman penangguhan pemeriksaan sebelumnya

- Tanggal melakukan transfusi darah terakhir

- Informed consent tertulis

\section{B. Umur}

Syarat menjadi pendonor minimal berusia 17 tahun. Namun ada beberapa negara yang mempunyai batasan usia minimal adalah 16 tahun tergantung dari aturan oleh hukum negara tersebut. Izin orang tua diperlukan untuk pendonor yang berusia kurang dari 18 tahun.

\section{Donor Darah Sebelumnya}


Pendonor whole blood berhak untuk mendonorkan setiap 56 hari (8 minggu) sekali. Pendonor apheresis (plateletpheresis, leukopheresis, dan plasmapheresis) dapat mendonorkan darah minimal 48 jam setelah pheresis selesai, sebelum melakukan donor whole blood.

\section{Edukasi Donor}

Calon pendonor perlu diberikan materi edukasi tentang donor darah. Materi tersebut meliputi informasi tentang penyakit menular yang dapat ditularkan melalui transfusi darah; tanda dan gejala AIDS. Informasi tambahan pra-donasi, seperti: pentingnya memberikan informasi yang akurat; kebebasan untuk menarik diri dari proses donasi dengan alasan apapun jika mereka merasa tidak cocok untuk melakukan transfusi. Setelah pendonor memahami dan materi yang telah dibaca kemudian ditandatangani.

\section{E. Persetujuan Pendonor}

Sebelum melakukan transfusi darah, pendonor harus menandatangani persetujuan tertulis (informed consent) untuk pengambilan darah. Pendonor harus memiliki kebebasan untuk mengajukan pertanyaan, menerima jawaban atas pertanyaanpertanyaan tersebut, dan akhirnya dapat membuat pilihan menyetujui ataupun menolak melakukan donor darah. Setiap donor di edukasi tentang risiko dari prosedur dan pemeriksaan penyakit menular yang akan dilakukan pada sampel darah. Penjelasan diberikan tentang pemberitahuan hasil tes positif. Donor diberitahu bahwa ia akan diberitahu jika pemeriksaan sampel darah berpotensi pada penularan penyakit menular. Selain itu, donornya diinformasikan bahwa penangguhan dari donor darah di kemudian 
hari akan terjadi jika hasil pemeriksaan penyakit menular adalah positif. Donor akan memiliki kesempatan untuk menundanya secara rahasia. Donor dapat memilih: "transfusi darah saya" atau "jangan transfusi darah saya."

Donor yang melakukan vaksinasi kemungkinan memerlukan masa penangguhan sebelum melakukan transfusi. Vaksin yang terbuat dari organisme yang mati atau toksoid tidak memerlukan mengalami penundaan. Donor harus bebas dari gejala. Vaksin hepatitis $A$ dan meningitis tidak memerlukan penangguhan jika mereka diberikan untuk pencegahan daripada paparan. Vaksin rutin seperti influenza dan tetanus tidak memerlukan penangguhan, jika donor tidak menunjukkan gejala dan tidak demam. Tabel 3.1 menunjukkan masa penangguhan sementara untuk administrasi vaksin. Sedangkan pendonor yang membutuhkan penangguhan 12 bulan bertujuan untuk memberi perlindungan terhadap penerima atau resipien. Penangguhan ini ada pada Tabel 3.2.

\section{F. Pemeriksaan Fisik}

Pemeriksaan fisik meliputi pemeriksaan kesehatan umum dan tanda-tanda vital untuk memastikan kesehatan yang baik pada pendonor. Pendonor harus tampak sehat pada saat akan melakukan donor darah. Pemeriksaan pendonor harus memperhatikan keadaan umum, jawaban terhadap pertanyaan tentang kesehatan, riwayat kesehatan, dan faktor resiko terkait gaya hidup dan beberapa pemeriksaan sederhana. Darah yang akan didonorkan sebanyak kurang lebih $525 \mathrm{ml}$ termasuk sampel untuk pemeriksaan sebelum darah di berikan kepada resipien. Kriteria pemeriksaan fisik bagi pendonor, antara lain:
a). Hemoglobin $\geq 12,5 \mathrm{~g} / \mathrm{dl}$
b). Hematokrit $\geq 38 \%$ 
c). Tekanan darah sistolik $\leq 180 \mathrm{mmHg}$, dan diastolik $\leq 100 \mathrm{mmHg}$

d). Temperatur $\leq 37,5^{\circ} \mathrm{C}$

e). Denyut nadi antara 50 s.d 100 kali/menit

f). Berat badan $\geq 50 \mathrm{~kg}$

\section{G. Flebotomi}

Seorang flebotomis akan memeriksa area antecubital kedua lengan pendonor. Pemeriksaan ini bertujuan menempatkan pembuluh darah yang tepat untuk dilakukan pengambilan darah. Flebotomis juga memeriksa bukti penggunaan obat intravena dan adanya lesi kulit. Lengan yang digunakan untuk pengambilan darah harus bebas dari lesi kulit pada hari dilakukannya donasi darah.

Sebelum dilakukan pengambilan darah, lengan harus di desinfeksi dengan menggunakan larutan scrub berair $70 \%$ dari senyawa iodophor untuk menghilangkan kotoran dipermukaan lengan, diikuti oleh larutan 10\% PVP-iodine. Desinfeksi dilakukan dengan gerakan melingkar memutar kearah luar. Area yang disiapkan harus dibiarkan kering selama 30 detik dan dapat ditutup dengan kain kasa steril sebelum dilakukan venipuncture.

Dengan menggunakan manset sphygmomanometer yang dipompa sampai dengan 40 hingga $60 \mathrm{mmHg}$ dapat melebarkan pembuluh darah vena untuk memudahkan proses mengeluarkan darah. Untuk pengambilan darah dipilih jarum 16-gauge yang melekat pada kantung darah primer. Venipuncture dilakukan pada vena di antekubital, dan harus bebas dari lesi kulit.

Tabel 3.1 Masa Penangguhan Sementara untuk Administrasi Vaksin

\begin{tabular}{ll}
\hline Masa Penangguhan & Jenis Vaksin \\
\hline 7 Hari & Hepatitis B (Not for Exposure) \\
2 Minggu & Measles (Rubeola) \\
& Mumps \\
\hline
\end{tabular}




\begin{tabular}{ll}
\hline & Yellow Fever \\
& Polio (Oral) \\
& Typhoid (Oral \\
& German Measles (Rubella) \\
& Measles, Mumps, Rubella \\
& Combination Vaccine \\
& Varicella Zoster (Chicken Pox) \\
& Smallpox \\
& Hepatitis B Immune Globulin \\
& Rabies Vaccine, Unless for \\
& Prevention \\
& Experimental/unlicensed Vaccine if \\
& Participating in a Research Study \\
\hline
\end{tabular}

(Whitlock, 2010)

Tabel 3.2 Masa Penangguhan Donor Darah Selama 12 Bulan

Penundaan 12 Bulan

- Tato

- Paparan membran mukosa atau penetrasi kulit terhadap darah

- Kontak seksual dengan seseorang yang berisiko tinggi untuk virus human immunodeficiency

- Penahanan di lembaga pemasyarakatan selama lebih dari 72 jam

- Korban pemerkosaan

- Kembali dari daerah endemis malaria

- Tes positif untuk sifilis

- Penyelesaian terapi untuk sifilis atau gonore

- Transfusi darah, komponen, atau turunannya 
- Transplantasi organ

(Whitlock, 2010)

\section{H. Reaksi Donor}

Reaksi negatif pendonor dapat terjadi pada saat proses screening, pengambilan darah, dan setelah selesai donor darah. Sebagian besar reaksi bersifat minor dan dapat segera diatasi oleh staf bank darah. Namun reaksi yang serius seperti kejang sampai dengan henti jantung dapat terjadi, meskipun jarang. Seorang flebotomis harus mampu mengenali gejala awal reaksi dan memberikan pertolongan pertama ketika diindikasikan. Kemungkinan gejalanya, antara lain: pucat, berkeringat, pusing, nafas cepat, mual, dan pingsan. Apabila gejala ini muncul, maka proses pengambilan darah harus segera dihentikan dan segera dilakukan penanganan serta perawatan yang tepat. Berbagai reaksi negatif donor beserta penangannya ada pada Tabel 3.3.

Setelah selesai melakukan donor darah, pendonor harus memulai proses rehidrasi dengan cara segera memberikan minuman dan makanan ringan. Pendonor disarankan untuk mengkonsumsi cairan ekstra selama 72 jam ke depan. Instruksi khusus setelah donasi, meliputi:

- Tidak mengonsumsi alkohol sampai pertama kali mengonsumsi makanan.

- Tidak merokok selama 30 menit

Tabel 3.3 Reaksi Negatif Donor dan Penanganannya

\begin{tabular}{ll} 
Keadaan & Penanganan \\
\hline Hematoma & Berikan tekanan pada area hematoma; \\
& selanjutnya kompres dengan es
\end{tabular}


Pucat,

berkeringat,

pusing, bernapas

cepat, mual

Kejang otot dan Bernapaslah ke dalam kantong kertas kedutan

Syncope (pingsan) - Kepala diturunkan dan kaki di angkat

- Oleskan kompres dingin ke dahi dan belakang leher

- Oleskan minyak kayu putih atau bahan aromatik lainnya

Kejang - Memanggil bantuan darurat

- Pertahankan jalan napas

- Lindungi donor dari cedera sampai bantuan datang

Gejala Jantung - Hubungi bantuan darurat

- Lakukan CPR

(Cardiopulmonary Resuscitation) jika diperlukan

- Naikkan kaki lebih tinggi sekitar $30 \mathrm{~cm}$ dari dada (untuk mengembalikan aliran - lakukan kompres air dingi

- lakukan kompres air dingin di dahi dan belakang leher

(Whitlock, 2010) 
autologus pra operasi mengacu pada teknik dimana sebelum operasi dilakukan pengambilan darah pada pasien dan disimpan pada jangka waktu tertentu, kemudian ditransfusikan kembali selama operasi. Metode ini memiliki beberapa kelebihan, antara lain: donor darah berulang sebelum operasi mampu menstimulasi proliferasi sel pada sumsum tulang, menstimulasi regenerasi eritrosit, meningkatkan fungsi hematopoietic pada pasien setelah operasi, mempercepat pemulihan hematopoietic setelah operasi, kondusif untuk penyembuhan luka, serta mengurangi kemungkinan infeksi yang disebabkan oleh reaksi imunologi dari transfusi darah alogenik.

\section{B. Directed Donation (Penunjukan Pendonor)}

Directed Donation adalah seseorang, umumnya orangtua, anggota keluarga, maupun teman yang mendonorkan darahnya khusus bagi pasien sebelum jadwal transfusi darah. Directed donor tidak lebih aman daripada donor komunitas, dan juga harus dilakukan pemeriksaan untuk penyakit menular seperti umumnya pemeriksaan sebelum donor darah. Directed donor bisa menjadi kurang aman jika seseorang merasakan tekanan dari keluarga atau teman untuk mendonorkan darahnya karena merasa tidak nyaman mengungkapkan informasi kesehatan penting yang akan membuatnya tidak memenuhi syarat sebagai pendonor.

\section{Flebotomi Therapeutic}

Flebotomi terapeutik merupakan pengobatan khusus untuk kelainan darah di mana pemindahan eritrosit atau serum iron adalah metode yang paling efisien untuk manajemen gejala dan komplikasi. Flebotomi terapeutik diindikasikan untuk pengobatan hemochromatosis, polycythemia vera, porphyria cutanea tarda, penyakit sel sabit, dan penyakit hati berlemak nonalkohol dengan hiperferritinemia. Selain itu, flebotomi dapat dianggap sebagai 
komponen dari pengobatan untuk pasien dengan kadar serum iron tinggi. Namun, penting untuk membuat keputusan perawatan berdasarkan kondisi setiap pasien dan pedoman yang relevan untuk menerapkan metode flebotomi therapeutic.

\section{Therapeutic Apheresis}

Apheresis berarti "memindahkan" dan heme mengacu pada "darah". Pada hemapheresis artinya whole blood dipindahkan dari donor atau pasien dan dipisahkan menjadi beberapa komponen. Satu atau lebih komponen dipertahankan, dengan bagian yang tersisa digabungkan kembali dan dikembalikan kepada donor atau pasien. Teknologi ini memungkinkan untuk hanya memilih komponen yang dibutuhkan atau otomatis memproduksi beberapa komponen. Sel darah, trombosit, plasma, dan/ atau granulosit dapat dikumpulkan menggunakan perangkat pengumpulan darah otomatis berdasarkan teknologi apheresis. Contoh alat therapeutic apheresis ada pada Gambar 3.1. Berikut ini merupakan daftar penyakit yang dilakukan pengobatan dengan apheresis terapeutik:

- Kondisi hematologi/ onkologi

- Paraproteinemia

- Hiperleukositosis

- Trombositemia

- Thrombotic thrombocytopenic purpura/ hemolytic uremic syndrome

- Penyakit sel sabit

- Purpura pasca transfusi

- Kondisi neurologi

- Acute Guillain-Barré syndrome

- Polineuropati inflamasi kronis

- Myasthenia gravis

- Cryoglobulinemia 
- Rapidly progressive glomerulonephritis associated with antibody to neutrophil cytoplasmic antigen

- Hiperkolesterolemia familial tipe II homozigot

- Refsum disease

Therapeutic apheresis merupakan prosedur dimana darah pasien dialirkan melalui alat medis ekstrakorporeal yang memisahkan komponen darah untuk mengobati suatu penyakit. Therapeutic apheresis tidak termasuk pengambilan sel punca (stem cell) untuk digunakan dalam transplantasi sumsum tulang/ sel punca. Umumnya dilakukan di fasilitas rawat jalan dan prosesnya membutuhkan beberapa jam. Berikut ini adalah istilah umum yang mencakup semua prosedur berdasarkan apheresis:

- Leukocytapheresis (LCP): prosedur di mana darah pasien atau donor dialirkan melalui perangkat medis yang memisahkan leukosit (misalnya: leukemia blast atau granulosit), mengumpulkan sel yang dipilih, dan mengembalikan sisa darah pasien atau donor darah dengan atau tanpa penambahan cairan pengganti, seperti larutan koloid dan/ atau kristaloid.

- Platelet Apheresis: prosedur di mana darah donor dialirkan melalui perangkat medis yang memisahkan trombosit, mengumpulkan trombosit, dan mengembalikan sisa darah donor. Prosedur ini digunakan dalam persiapan komponen darah (misalnya: Trombosit apheresis).

- Erythrocytapheresis: prosedur di mana darah pasien atau donor dialirkan melalui perangkat medis yang memisahkan eritrosit dari komponen darah lainnya. Eritrosit dikeluarkan dan diganti dengan kristaloid atau larutan koloid, bila perlu.

- Plasmaferesis: Prosedur di mana darah pasien atau donor dialirkan melalui perangkat medis yang memisahkan plasma dari 
komponen darah lainnya dan plasma dikeluarkan (yaitu, kurang dari $15 \%$ dari total plasma.

- Thrombocytapheresis: prosedur terapi di mana darah pasien dialirkan melalui alat kesehatan yang memisahkan trombosit, membuang trombosit, dan mengembalikan sisa darah pasien dengan atau tanpa penambahan cairan pengganti seperti larutan koloid dan / atau kristaloid.

- Adsorptive Cytapheresis: Prosedur terapeutik di mana darah pasien dialirkan melalui perangkat medis, yang berisi kolom atau filter yang secara selektif mengabsorpsi monosit dan granulosit, memungkinkan leukosit yang tersisa dan komponen darah lainnya untuk dikembalikan ke pasien.

- Extracorporeal Photopheresis (ECP): Prosedur terapeutik di mana buffy coat dipisahkan dari darah pasien, diperlakukan secara ekstrakorporeal dengan senyawa fotoaktif (misalnya, psoralens) dan diteruskan sinar ultraviolet $\mathrm{A}$ kemudian diinfuskan kembali ke pasien selama prosedur yang sama.

- $\boldsymbol{R B C}$ Exchange: Prosedur terapeutik di mana darah pasien dialirkan melalui perangkat medis memisahkan sel darah merah dari komponen darah lainnya. Sel darah merah pasien diangkat dan diganti dengan donor sel darah merah dan larutan koloid.

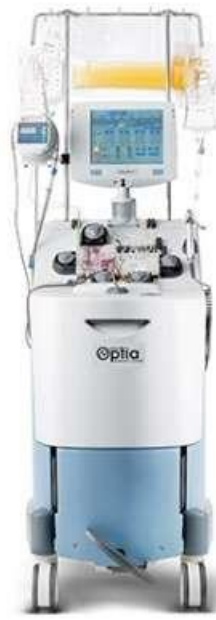


Gambar 3.1 Alat Therapeutic Apheresis (www.terumobct.com)

\section{RANGKUMAN :}

- Darah merupakan cairan kompleks terdiri dari sel-sel darah (eritrosit, leukosit, trombosit) yang tersuspensi dalam cairan kekuningan yang disebut plasma.

- Bentuk eritrosit tampak seperti cakram bikonkaf, mempunyai diameter 7,2 mikron dan terdapat sekitar 5 juta sel eritrosit per $\mathrm{mm}^{3}$ darah $\left(5 \times 10^{12} / \mathrm{L}\right)$. Eritrosit mengandung hemoglobin yang memiliki fungsi utama dalam membawa oksigen ke jaringan tubuh.

- Leukosit merupakan sel yang memiliki inti yang terdiri dari granulosit dan agranulosit. Granulosit terdiri dari: neutrofil, 
eosinofil, dan basofil. Sedangkan agranulosit meliputi: limfosit dan monosit. Nilai normal jumlah leukosit adalah 4000 - 11.000 leukosit per $\mathrm{mm}^{3}$ (4,0 - 11,0 × 10\%/L) darah

- Ukuran trombosit jauh lebih kecil daripada eritrosit dan leukosit. Nilai normal jumlah trombosit adalah $150.000-500.000$ per $\mathrm{mm}^{3}$ (150 - $\left.500 \times 10^{9} / \mathrm{L}\right)$ darah. Trombosit berperan penting dalam mekanisme pembekuan darah.

- Proses screening donor meliputi tiga fase, yaitu: pendaftaran, wawancara riwayat kesehatan, dan pemeriksaan fisik. Hal yang harus diperhatikan untuk kriteria pendonor meliputi: registrasi, umur, donor darah sebelumnya, edukasi donor, persetujuan donor.

- Reaksi negatif pendonor dapat terjadi pada saat proses screening, pengambilan darah, dan setelah selesai donor darah. Sebagian besar reaksi bersifat minor dan dapat segera diatasi oleh staf bank darah. Namun reaksi yang serius seperti kejang sampai dengan henti jantung dapat terjadi, meskipun jarang.

- Terdapat beberapa transfusi darah alternatif, antara lain: donor autologous, directed donation, flebotomi therapeutic, dan therapeutic apheresis.

\section{LATIHAN SOAL :}


1. Bagian darah yang berfungsi mengangkut oksigen ke berbagai jaringan guna menyediakan energi dan panas bagi tubuh serta berfungsi memberi warna merah pada eritrosit adalah
a. Plasma
b. Serum
c. Hemoglobin
d. Fibrinogen
e. Platelet

2. Masa hidup granulosit adalah
a. 100 hari
b. 60 hari
c. 30 hari
d. 1-7 hari
e. 3-5 hari

3. Sel darah yang disebut sebagai scavenger cells adalah ..........
a. Eosinofil
b. Basofil
c. Neutrofil
d. Limfosit
e. Monosit

4. Sel darah yang melepaskan substansi di lokasi luka atau cedera dan bergabung dengan faktor pembekuan lain dalam plasma untuk menghasilkan benang protein halus (fibrin) adalah ..........
a. Eritrosit
b. Leukosit
c. Platelet
d. Limfosit
e. Monosit 
5. Berikut ini yang merupakan informasi penting dalam registrasi pendonor, kecuali:
a. Nama Lengkap
b. Umur
c. Tanggal lahir
d. Jenis kelamin
e. Diagnosa penyakit

6. Sebelum melakukan transfusi darah, pendonor harus menandatangani persetujuan tertulis untuk pengambilan darah yang disebut
a. informed consent
b. ethical clearance
c. Blanko registrasi
d. Blanko identitas pasien
e. Surat Sehat

7. Berikut ini kriteria pemeriksaan fisik untuk melakukan donor darah, yaitu:
a. Hemoglobin $\leq 12,5 \mathrm{~g} / \mathrm{dl}$
b. Hematokrit $\leq 38$
c. tekanan darah $\geq 180 / 100 \mathrm{mmHg}$
d. Berat badan $\geq 50 \mathrm{~kg}$
e. Temperatur $\geq 37,5^{\circ} \mathrm{C}$

8. Masa penangguhan sementara bagi pendonor darah setelah melakukan vaksinasi hepatitis $\mathrm{B}$ adalah ..........
a. 7 hari
b. 2 minggu
c. 4 minggu
d. 8 minggu
e. 12 bulan

9. Instruksi khusus yang harus diperhatikan bagi seseorang yang telah mendonorkan darahnya adalah 

a. Tidak merokok
b. Tidak mengonsumsi alkohol
c. Mencegah perdarahan di area flebotomi
d. Mengonsumsi cairan ekstra
e. Semua jawaban benar

10.pengambilan darah untuk ditransfusikan ke pendonor di kemudian hari dinamakan ..........
a. Donor autologous
b. Directed donation
c. Flebotomi Therapeutic
d. Plasmaferesis
e. Therapeutic Apheresis 


\section{REFERENSI :}

Anastasiadi, A. T., Tzounakas, V. L., Kriebardis, A. G., Stamoulis, K. E., Seghatchian, J., \& Antonelou, M. H. (2020). When I need you most: frozen red blood cells for transfusion. Transfusion and Apheresis Science, Vol. 59, 1-4. https://doi.org/10.1016/j.transci.2020.102786.

Kim, K. H., \& Oh, K. Y. (2016). Clinical applications of therapeutic phlebotomy. Journal of Blood Medicine, Vol. 7, 139-144. doi: 10.2147/JBM.S108479

Quinley, E. D. (2011). Immunohematology Principles \& Practice. Third Edition. Philadelphia: Lippincott Williams \& Wilkins.

Stanford Blood Center. (2016). Directed Blood Donation Information. Palo Alto California. Retrieved from https://stanfordbloodcenter.org/wp-

\section{content/uploads/2017/06/03-}

F09Form DirectedDonationInfoSheet.pdf

United Health Care. (2018). Apheresis. Britain: Oxford Health Plans.

Retrieved from

https://www.oxhp.com/secure/policy/apheresis.pdf

Whitlock, S. A. (2010). Immunohematology For Medical Laboratory

Technicians. USA: Delmar, Cengage Learning.

World Health Organization (WHO). (2009). Safe Blood and Blood

Products, Module 3, Blood Group Serology. USA: WHO Press.

Zhou, J. (2016). A Review of the Application of Autologous Blood

Transfusion. Brazilian Journal of Medical and Biological

Research, 49(9), 1-6. doi: 10.1590/1414-431X20165493.

Spectra Optia Apheresis System. Retrieved from

https://www.terumobct.com/spectra-optia. 


\section{BAB 4 \\ TEKNOLOGI PENGOLAHAN DARAH}

\section{Sub - Capaian Pembelajaran Mata Kuliah :}

- Mampu memahami tentang preparasi sebelum melakukan pengambilan darah pada pendonor.

- Mampu memahami mengenai fraksi komponen darah yang dapat di donorkan.

- Mampu menjelaskan cara pengolahan dan penyimpanan komponen darah. 
Transfusi darah dalam bentuk Whole blood memberikan manfaat yang hanya menguntungkan satu pasien. Oleh karena itu diperlukan teknologi pengolahan darah sehingga darah utuh (whole blood) dapat dibagi menjadi beberapa bagian atau komponen. Penggunaan komponen darah memaksimalkan penggunaan darah yang merupakan sumber daya yang terbatas namun berharga. Fraksinasi whole blood menjadi beberapa komponen memungkinkan pasien untuk menerima terapi paling efektif dengan produk yang lebih aman daripada whole blood. Pembagian whole blood menjadi beberapa komponen memberikan manfaat maksimal bagi banyak resipien, bukan hanya bagi satu pasien.

Food and Drug Administration (FDA) atau Badan Pengawas Obat dan Makanan (BPOM) mengatur pengumpulan dan fraksinasi whole blood. Bank darah dan layanan transfusi yang melakukan pengambilan whole blood dan fraksinasi komponen darah harus mengikuti Good Manufacturing Practices (GMP) dan mematuhi pedoman BPOM. Prosedur pengumpulan awal, persiapan komponen, pelabelan, penyimpanan, dan distribusi semua komponen merupakan proses vital dalam bank darah. Pada bab ini akan membahas tentang komponen whole blood, metode persiapan, pelabelan, penyimpanan, dan penggunaan yang tepat dari setiap komponen darah.

\subsection{PREPARASI DONOR DARAH}

\section{A. Kantong Darah}

Kantong penampung darah tersedia secara komersial dalam berbagai konfigurasi. Wadah darah ini harus tidak berwarna dan transparan untuk memungkinkan memeriksa isinya dan harus di tutup sedemikian rupa untuk menjaga segel kedap udara dan mencegah kontaminasi. Kantong darah bahannya tidak boleh 
mempengaruhi isinya pada saat penyimpanan dan penggunaan biasa (sehari-hari).

Semua kantong darah memiliki bagian dalam yang steril, termasuk jarum dan semua tabung yang terpasang, dan mengandung larutan pengawet antikoagulan. Larutan pengawet antikoagulan bervariasi tergantung produsennya. Sistem pengumpulan darah yang ideal adalah sistem tertutup. Sistem tertutup terdiri dari kantong utama dan satu atau lebih kantong satelit. Kantong yang saling berhubungan memungkinkan pemindahan komponen dari kantong aslinya tanpa adaya paparan udara ke produk darah. Ini menjaga sterilitas komponen darah dan memungkinkan eritrosit mempertahankan tanggal kadaluwarsa dari whole blood. Sedangkan pada sistem terbuka, prosesnya meningkatkan resiko paparan kontaminasi pada komponen darah dan perubahan tanggal kadaluwarsa komponen. Contoh kantong darah ada pada Gambar 4.1. Berbagai jenis kantong darah dan komponennya ditunjukkan pada Tabel 4.1.

\section{B. Antikoagulan}

Antikoagulan dalam kantong darah (whole blood collection set) akan bercampur dengan darah donor selama proses pengambilan darah. Antikoagulan pada kantong darah akan mencegah darah menggumpal selama proses pengambilan darah. Antikoagulan utama yang digunakan adalah citrate-phosphate dextrose (CPD), citratephosphate-2-dextrose (CP2D), dan citrate-phosphate-dextrose plus adenine (CPDA1). Komposisi masing-masing antikoagulan dijelaskan pada Tabel 4.1. 


\section{Gambar 4.1 Kantong darah (www.fosmedic.com)}

Semua antikoagulan mengandung sitrat, yang mengkelat (mengikat) kalsium dalam darah, sehingga menghambat langkahlangkah yang bergantung pada kalsium dalam kaskade koagulasi. Antikoagulan juga mengandung natrium bifosfat yang menjaga $\mathrm{pH}$ komponen selama penyimpanan. Mempertahankan tingkat $\mathrm{pH}$ diperlukan untuk mempertahankan tingkat 2,3-difosfogliserat (2,3DPG) yang memadai. Eritrosit menyalurkan oksigen $\left(\mathrm{O}_{2}\right)$ dari paruparu ke jaringan tubuh dengan menggunakan perbedaan afinitas untuk molekul $\mathrm{O}_{2}$. Di area dengan tekanan parsial tinggi seperti paruparu, afinitas eritrosit untuk $\mathrm{O}_{2}$ meningkat. Saat eritrosit berjalan ke jaringan dan tekanan parsial menurun, afinitas oksigen menurun dan molekul oksigen dilepaskan dari eritrosit ke jaringan. Jumlah 2,3-DPG dalam darah memodulasi keefektifan eritrosit untuk oksigen. Meskipun kadar 2,3-DPG menurun pada 2 minggu pertama penyimpanan, kadar eritrosit yang ditransfusikan akan beregenerasi dalam 12 hingga 24 jam setelah transfusi. Ringkasan tentang berbagai antikoagulan ada pada Tabel 4.2. Kantong darah dengan 63 $\mathrm{ml}$ antikoagulan untuk menyimpan $450 \pm 45 \mathrm{ml}$ darah. Sedangkan kantong darah dengan $70 \mathrm{ml}$ antikoagulan untuk menyimpan $500 \pm$ $50 \mathrm{ml}$ darah.

Tabel 4.1 Berbagai Tipe Kantong Darah dan Komponennya pada 
Sistem Tertutup

\begin{tabular}{lcl}
\hline $\begin{array}{l}\text { Tipe Kantong } \\
\text { Darah }\end{array}$ & $\begin{array}{c}\text { Jumlah Kantong } \\
\text { Satelit }\end{array}$ & Komponen \\
\hline Single & 0 & Whole blood \\
Double & 1 & $\begin{array}{l}\text { Eritrosit/ plasma } \\
\text { Triple }\end{array}$ \\
& 2 & $\begin{array}{l}\text { Eritrosit/ platelet/ } \\
\text { plasma atau eritrosit/ } \\
\text { cryoprecipitate/ plasma } \\
\text { Eritrosit/ platelet/ } \\
\text { cryoprecipitate/plasma }\end{array}$ \\
\hline
\end{tabular}

(Quinley, 2011)

\section{Larutan Aditif}

Larutan aditif berfungsi untuk memperpanjang lama penyimpanan eritrosit. Larutan aditif mengandung saline, adenin, dan dekstrosa atau meningkatkan pembentukan ATP, dan zat minor lainnya yang meningkatkan viabilitas eritrosit dalam kantong darah. Tanggal kedaluwarsa eritrosit dapat diperpanjang menjadi 42 hari. Komposisi absolut dari larutan aditif bervariasi menurut produsen blood collection set. Larutan aditif ditambahkan ke eritrosit setelah plasma dipisahkan/ dimasukkan ke dalam kantong darah satelit. Hematokrit terakhir dari eritrosit yang mengandung larutan aditif antara 55\% dan 65\% dibandingkan dengan eritrosit tanpa larutan aditif yang harus kurang dari $80 \%$. Hematokrit dan viskositas yang menurun dari eritrosit aditif memfasilitasi peningkatan aliran darah selama transfusi. Larutan aditif harus ditambahkan ke eritrosit dalam waktu 72 jam setelah pengambilan darah atau sesuai petunjuk pabrik.

Tabel 4.2 Berbagai Antikoagulan dalam kantong Darah

\begin{tabular}{|c|c|c|c|c|c|c|c|c|c|}
\hline \multirow[b]{2}{*}{ Voriable } & \multicolumn{2}{|c|}{$C P D$} & \multicolumn{4}{|c|}{ CPDA-1 } & \multirow{2}{*}{$\begin{array}{c}\text { AS-1" } \\
\text { Red } \\
\text { Blood } \\
\text { Colls }\end{array}$} & \multirow{2}{*}{ 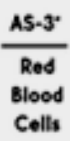 } & \multirow{2}{*}{$\begin{array}{l}\text { AS-5 } \\
\text { Red } \\
\text { Blood } \\
\text { Cells }\end{array}$} \\
\hline & $\begin{array}{l}\text { Whole } \\
\text { Blood }\end{array}$ & $\begin{array}{c}\text { Red } \\
\text { Blood } \\
\text { Colls }\end{array}$ & $\begin{array}{l}\text { Whole } \\
\text { Blood }\end{array}$ & $\begin{array}{c}\text { Red } \\
\text { Blood } \\
\text { Cells }\end{array}$ & $\begin{array}{l}\text { Whole } \\
\text { Blood }\end{array}$ & $\begin{array}{c}\text { Red } \\
\text { Blood } \\
\text { Cells }\end{array}$ & & & \\
\hline Days of storage & 0 & 21 & 0 & 0 & 35 & 35 & 42 & 42 & 42 \\
\hline 96 Viable cells (24 h posttransfusion) & 100 & 80 & 100 & 100 & 79 & $\pi$ & 76 & 83 & 80 \\
\hline pht (measured at $37^{\circ} \mathrm{C}$ ) & 7.20 & 6.84 & 7.55 & 7,60 & 6.98 & 6.71 & 66 & 6.5 & 6.5 \\
\hline ATP ( 8 of initial value) & 100 & 86 & 100 & 100 & 56 & 45 & 60 & 58 & 68.5 \\
\hline
\end{tabular}


(Quinley, 2011)

\subsection{KOMPONEN DONOR DARAH}

\section{A. Whole Blood}

Penggunaan darah utuh (whole blood) untuk transfusi selama 30 tahun terakhir sangat jarang. Hal ini terjadi karena adanya teknologi untuk mempersiapkan dan menyimpan setiap komponen darah secara terpisah demi memaksimalkan sifat spesifik terapeutiknya. Meskipun whole blood mengandung semua komponen seluler dan plasma darah, faktor koagulasi labil berkurang seiring waktu dan trombosit menjadi tidak berfungsi pada suhu penyimpanan $1^{\circ} \mathrm{C}$ hingga $6^{\circ} \mathrm{C}$. Unit rata-rata whole blood yang dikumpulkan biasanya 450 atau $500 \mathrm{~mL}$ darah ( \pm 10\%) ditambah antikoagulan terukur yang sesuai. Indikasi klinis untuk whole blood sedikit dan transfusi whole blood harus disediakan untuk beberapa pasien yang membutuhkan penggantian volume dan kapasitas pengangkutan oksigen. Fresh whole blood yang telah diuji sepenuhnya dapat digunakan untuk transfusi pada neonatal. Pembagian unit whole blood menjadi beberapa komponen ada pada Gambar 4.2.

\section{B. Red Blood Cell (Eritrosit)}

Tiga komponen darah utama, yaitu eritrosit, trombosit, dan plasma. Ini dibuat dari whole blood melalui proses sentrifugasi 
diferensial untuk memisahkan berbagai komponen. Memvariasikan waktu putaran centrifus dan kecepatan putaran (rpm) menghasilkan komponen yang berbeda berdasarkan parameter hasil yang optimal dan kebutuhan produk pasien.

Setelah unit whole blood disentrifugasi, plasma dipisahkan dari eritrosit melalui port akses internal ke salah satu kantong satelit yang terpasang pada collection set. Penting untuk menggunakan sistem tertutup (closed system). Jika larutan aditif tidak digunakan, maka plasma harus tetap bersama eritrosit untuk memastikan hematokrit kurang dari $80 \%$. Jika hematokrit dari eritrosit tanpa aditif lebih dari $80 \%$, maka suplai nutrisi dan pengawet yang ada kemungkinan tidak dapat mempertahankan eritrosit selama penyimpanan. Transfusi eritrosit diindikasikan untuk pasien yang membutuhkan massa eritrosit tambahan untuk kapasitas pembawa oksigen karena kehilangan darah atau proses penyakit yang mengurangi jumlah eritrosit. Satu unit eritrosit umumnya akan meningkatkan hematokrit pasien yang tidak perdarahan sekitar $3 \%$ dan hemoglobin sekitar 1 $\mathrm{g} / \mathrm{dL}$. Transfusi eritrosit diperlukan ketika hemoglobin menurun ke tingkat yang membutuhkan dukungan transfusi. Transfusi komponen laia

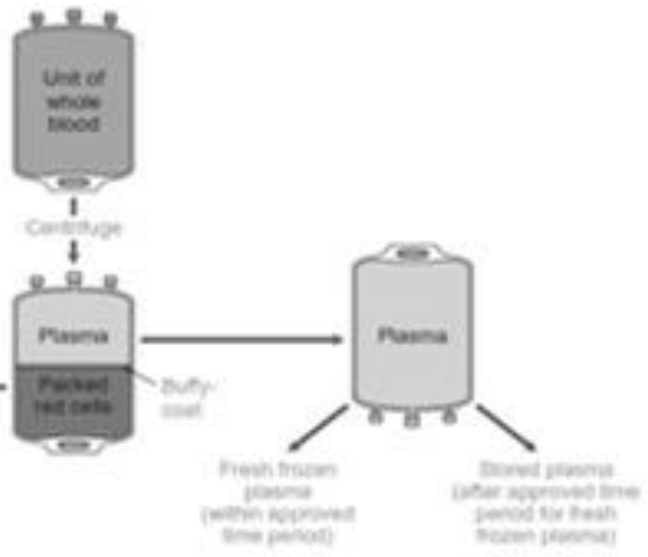


e.

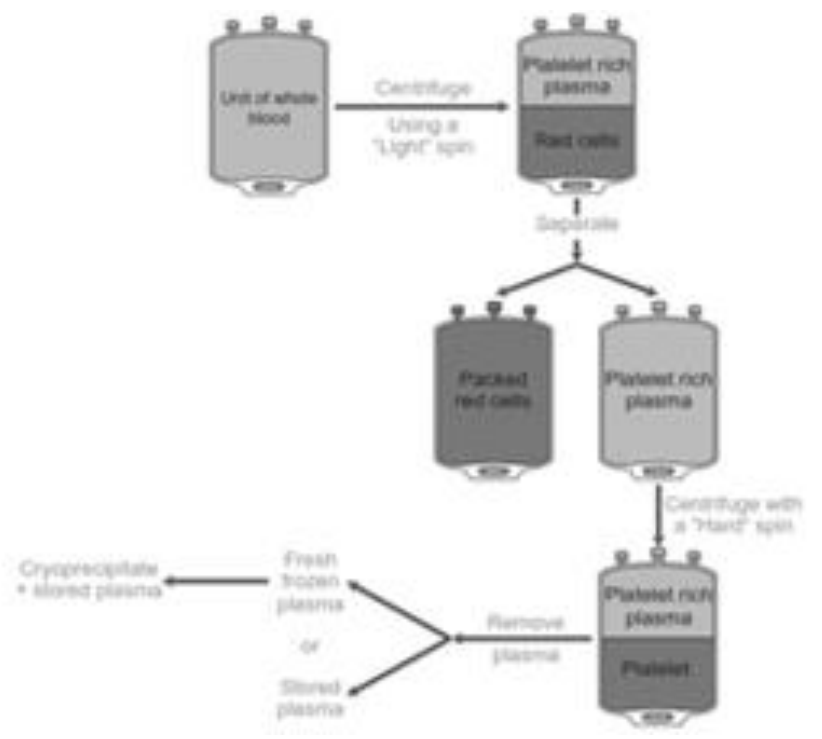

Gambar 4.2 (A). Persiapan Komponen dari Satu Unit Whole Blood Sentrifugasi Sederhana dan Pemisahan menjadi Plasma dan Packed Cells; (B) Pilihan konversi yang mungkin untuk Plasma dan Packed Cells (Whitlock, 2010)

bersamaan. Komponen tambahan akan menggantikan faktor koagulasi untuk mencegah perdarahan tambahan atau eksaserbasi dari kondisi klinis lainnya. Komponen ini mungkin termasuk FFP (Fresh Frozen Plasma) dan/ atau trombosit. Kondisi yang mungkin memerlukan transfusi eritrosit, antara lain:

- Anemia akut atau kronik

- Trauma

- Pembedahan

- Karsinoma, limfoma, leukemia

- Thalasemia;

- Anemia sel sabit 
- Penyakit ginjal

- Hemolytic Disease of the Fetus and Newborn (HDFN)

\section{Red Blood Cells Leukocytes Reduced}

Eritrosit sering dipersiapkan dengan metode untuk mengurangi leukosit atau massa leukosit. Beberapa alasan untuk membuang leukosit, yaitu:

- Untuk mengurangi resiko reaksi transfusi demam non-hemolitik

- Untuk mengurangi Human Leukocyte Antigen (HLA) atau granulocyte alloimmunization

- Untuk meminimalkan transmisi penyakit menular seperti cytomegalovirus (CMV)

- Untuk mengurangi jumlah reaksi transfusi yang merugikan terhadap simpanan darah dari enzim dan sitokin yang dilepaskan oleh leukosit saat mereka memburuk (deteriorate) dan pecah (fragment).

Beberapa metode tersedia untuk mempersiapkan Red Blood Cells Leukocytes Reduced untuk transfusi. Leukosit dapat dipisahkan dari eritrosit di samping tempat tidur pasien melalui penggunaan filter reduksi leukosit khusus yang dipasang pada set transfusi. Satu kelemahan dari teknik ini adalah tidak memiliki mekanisme kendali mutu untuk mengevaluasi keefektifan filter. Teknik ini juga tidak mencegah semua reaksi merugikan dan aloimunisasi ke fragmen leukosit yang terakumulasi di unit eritrosit yang disimpan. The American Association of Blood Banks (AABB) mensyaratkan bahwa unit Red Blood Cells Leukocytes Reduced memiliki $<5 \times 10^{6}$ leukosit per unit. Idealnya, pengurangan leukosit harus dilakukan sebelum penyimpanan eritrosit.

\section{Red Blood Cell Washed}


Red blood cell washed dilakukan bagi pasien defisiensi IgA, ketika komponen seluler defisiensi IgA tidak tersedia, atau jika pasien mengalami beberapa reaksi alergi yang semakin buruk terhadap unit yang ditransfusikan. Washing Red blood cell tidak dianggap sebagai metode yang efektif untuk mencapai leukoreduced RBCs. Washed cell biasanya disiapkan dengan perangkat pencuci sel otomatis, meskipun bisa dibuat dengan proses sentrifugasi manual. Mesin pencuci sel otomatis menambahkan saline $0,9 \%$ ke eritrosit, menyentrifugasi produk, dan kemudian memisahkan supernatan plasma dan campuran saline ke dalam kantong limbah. Proses ini diulangi beberapa kali menggunakan 1 hingga 2 L larutan saline. Karena sistem kantong darah tertutup terganggu dan karena semua nutrisi antikoagulan dan plasma juga hilang, maka tanggal kadaluwarsa dari eritrosit yang sudah dicuci adalah 24 jam dari saat sistem dibuka. Suhu penyimpanan tetap pada $1^{\circ} \mathrm{C}-6^{\circ} \mathrm{C}$.

\section{E. Red Blood Cell Frozen atau Red Blood Cell Deglycerolized}

Penyimpanan eritrosit pada suhu yang sangat rendah (pada -65 hingga $-196^{\circ} \mathrm{C}$ ) merupakan alternatif untuk penyimpanan cairan hipotermia (pada $4-6^{\circ} \mathrm{C}$ ). Metode ini bertujuan untuk memperpanjang umur seluler dalam waktu lama melalui penghentian aktivitas biologis. Pembekuan, bagaimanapun, dikaitkan dengan kerusakan permanen pada sel-sel hidup, tergantung pada laju pendinginan, kristal es dapat dibentuk secara ekstraseluler (laju lambat) atau intraseluler (laju tinggi). Selain itu, sel yang melewati zona suhu menengah (kira-kira antara -10 hingga $-60^{\circ} \mathrm{C}$ ) dapat merusak permeabilitas membran. Akibatnya, aditif krioprotektif sangat penting, dengan gliserol nontoksik menjadi yang paling banyak digunakan untuk kriopreservasi eritrosit. Ini memasuki sel melalui transportasi yang difasilitasi dan membatasi pembentukan kristal es, efek zat terlarut dan dehidrasi. Konsentrasinya bervariasi 
sesuai dengan protokol pembekuan: pada tingkat pendinginan yang lambat, konsentrasi gliserol tinggi digunakan untuk melawan ketidakseimbangan osmotik, sedangkan pada tingkat pendinginan tinggi gliserol dibutuhkan pada konsentrasi yang lebih rendah. Terdapat dua metode yang telah dikembangkan sesuai untuk penggunaan klinis, yaitu metode gliserol tinggi (HGM) dan metode gliserol rendah (LGM).

Eritrosit dapat dibekukan untuk digunakan dikemudian hari dalam keadaan tertentu. Sel-sel tanpa larutan aditif ini harus dibekukan dalam waktu 6 hari setelah pengumpulan. Eritrosit dengan larutan aditif dapat dibekukan kapan saja sebelum tanggal kadaluwarsanya. Red Blood Cell Frozen disimpan pada suhu $-65^{\circ} \mathrm{C}$. Alasan utama pembekuan eritrosit adalah untuk keadaan transfusi khusus, seperti penggunaan autologous, dan untuk menyimpan unit yang sangat langka berdasarkan fenotipe spesifik. Eritrosit yang dibekukan memiliki tanggal kadaluwarsa 10 tahun. Proses membekukan dan kemudian mencairkan serta menghilangkan lemak eritrosit apabila akan digunakan pasien memakan waktu, mahal, dan kehilangan massa eritrosit yang berharga. Setelah sel disiapkan untuk transfusi, proses sistem terbuka menyebabkan umur simpan yang pendek selama 24 jam, sehingga red blood cell frozen tidak praktis sebagai item persediaan rutin.

Penyakit menular baru dapat ditambahkan sebagai tes donor. Hal ini penting dilakukan karena sampel serum atau plasma dari donor unit beku untuk pengujian di masa mendatang sebab unit ini ditempatkan dalam penyimpanan jangka panjang (hingga 10 tahun). Unit langka yang belum ada diuji untuk penanda penyakit menular yang baru. Pelabelan produk harus mencerminkan dengan jelas tes yang belum dilakukan. Sebuah perangkat telah disetujui FDA untuk pembekuan sistem tertutup dan degliserolisasi eritrosit dalam waktu 6 hari setelah pengumpulan. Eritrosit bisa dibekukan selama 3 tahun. 
Karena perangkat ini memproses eritrosit dalam sistem tertutup, eritrosit tersebut tahan lama lebih dari 14 hari setelah pencairan.

Red Blood Cell Deglycerolized merupakan produk yang dibuat saat frozen cells dicairkan dan gliserol dihilangkan. Unit beku dicairkan pada $37^{\circ} \mathrm{C}$. Prosesor eritrosit otomatis digunakan untuk memproses sel yang dicairkan. Pencucian ganda dengan larutan saline menurunkan osmolitas digunakan. Proses ini mengeluarkan gliserol dari sel dan sel disuspensi kembali dalam konsentrasi saline yang digunakan dalam pencucian akhir. Konsentrasi saline yang digunakan adalah 12\%; 1,6\%; dan 0,9\%. Ini merupakan sistem terbuka dan kadaluwarsa unit adalah 24 jam setelah persiapan.

\section{F. Fresh Frozen Plasma (FFP)}

Ketika donor memberikan satu unit darah utuh (whole blood), darah tersebut dipisahkan menjadi beberapa bagian komponen. Komponen utama adalah packed Red Blood Cells (pRBC), FFP, dan terkadang trombosit. FFP dapat dipisahkan menjadi kriopresipitat dan apa yang dikenal sebagai "cryo-poor plasma" produk yang jarang digunakan untuk sarana terapeutik. Plasma merupakan cairan, bagian darah non-seluler, mengandung air, elektrolit, dan protein. Protein dalam plasma termasuk faktor pembekuan utama dan antikoagulan intrinsik. Plasma dipisahkan dari whole blood setelah donasi dan kemudian dibekukan. agar dianggap "fresh", plasma harus ditempatkan ke dalam freezer dalam waktu 8 jam setelah pengumpulan dan disimpan pada suhu $-18^{\circ} \mathrm{C}$ (dapat untuk penyimpanan selama 12 bulan) atau lebih rendah, jika tidak maka hanya plasma beku (produk lain yang jarang digunakan sebagai terapeutik). FFP dapat dibuat dengan memisahkan dari whole blood atau melalui plasmaferesis.

Fresh Frozen Plasma mengandung mayoritas dari semua faktor koagulasi yang diketahui, tetapi pada dasarnya tidak ada sel 
(misalnya eritrosit, leukosit atau trombosit). Selain faktor koagulasi, FFP juga mengandung sekitar 500 mg fibrinogen. Fibrinogen dalam 1 unit FFP kira-kira sama dengan jumlah fibrinogen yang ditemukan dalam 2 unit kriopresipitat. Faktor pembekuan dan fibrinogen ini sangat penting untuk hemostasis normal.

FFP diindikasikan untuk defisiensi faktor koagulasi dengan tes koagulasi abnormal ditandai adanya perdarahan aktif. FFP juga diindikasikan untuk pembedahan terencana atau prosedur invasif karena adanya tes koagulasi abnormal, untuk pembalikan warfarin yang disebabkan perdarahan aktif atau prosedur terencana ketika vitamin $\mathrm{K}$ tidak cukup untuk membalikkan efek warfarin, thrombotic thrombocytopenic purpura, dan congenital or acquired factor deficiency with no alternative therapy. Rekomendasi lain yang lebih spesifik untuk FFP berdasarkan tinjauan sistematis termasuk pasien trauma yang membutuhkan transfusi masif dan perdarahan intrakranial terkait warfarin. Kondisi yang menyebabkan defisiensi beberapa faktor koagulasi, mungkin memerlukan pemberian FFP termasuk penyakit hati dan disseminated intravascular coagulation (DIC). Transfusi FFP mungkin tidak dapat ditoleransi pada pasien dengan penyakit hati karena pasien kemungkinan tidak dapat mentolerir volume infus yang diperlukan untuk mencapai tingkat faktor koagulasi hemostatik yang memadai.

\section{G. Cryoprecipitated Antihemophilic Factor (CRYO)}

Faktor antihemofilik cryoprecipitated (CRYO) adalah produk yang dibuat dari plasma yang dikeluarkan dari eritrosit segera setelah pengambilan darah. Ini adalah konsentrat dari Faktor Koagulasi VIII, I (Fibrinogen), Faktor von Willebrand (vWF), dan fibronektin. Produk dipersiapkan dengan menghilangkan plasma dari eritrosit dan membekukannya menjadi campuran cair (slushy mixture). Pada saat itu, hasil dari bahan yang terkonsentrasi di dasar plasma adalah 
kriopresipitat. Plasma yang tersisa dibuang dan bahan kriopresipitat diberi label dan dibekukan.

Kriopresipitat awalnya dikembangkan sebagai terapi untuk pasien dengan defisiensi faktor antihemofilik, atau hemofilia $A$, telah digunakan selama hampir 50 tahun. Namun kini kriopresipitat paling sering digunakan untuk mengisi kembali kadar fibrinogen pada pasien dengan acquired coagulopathy, seperti keadaan klinis dengan perdarahan termasuk operasi jantung, trauma, transplantasi hati, atau pendarahan obstetrik. Kriopresipitat merupakan produk gabungan yang tidak mengalami inaktivasi patogen, dan pemberiannya telah dikaitkan dengan sejumlah efek samping, terutama penularan patogen melalui darah dan cedera paru akut terkait transfusi. Karena itu, bersamaan dengan ketersediaan sediaan fibrinogen alternatif, kriopresipitat telah ditarik dari penggunaan di sejumlah negara Eropa. Dibandingkan dengan plasma yang dibuat, kriopresipitat mengandung faktor koagulasi VIII dengan konsentrasi tinggi, faktor koagulasi XIII, dan fibrinogen. Kriopresipitat biasanya dilisensikan oleh otoritas regulasi untuk pengobatan hipofibrinogenaemia, dan direkomendasikan untuk suplementasi ketika kadar fibrinogen plasma turun di bawah $1 \mathrm{~g} / \mathrm{L}$.

\section{H. Platelet Concentrates (PC)}

Konsentrat trombosit dapat dibuat dari satu unit darah utuh (whole blood). Trombosit ini adalah trombosit donor "random" atau konsentrat trombosit. Trombosit donor tunggal ini harus menghasilkan minimal $5,5 \times 10^{10}$ trombosit per unit. Umur penyimpanan stok trombosit tergantung pada antikoagulan. Tanggal kadaluwarsa biasanya lima hari sejak tanggal pengambilan. Unit tunggal dapat digabungkan agar menghasilkan platelet concentrates dengan volume yang lebih besar untuk ditransfusikan ke penerima dewasa. Proses penyatuan melibatkan penggabungan trombosit dari 
satu unit dalam satu set transfer terpisah menggunakan teknik aseptik. Proses penggabungan ini menciptakan sistem terbuka. Trombosit yang terkumpul disimpan pada suhu 20 sampai 24 으 sampai ditransfusikan dan harus ditransfusikan dalam waktu empat jam.

Penggunaan pooled platelet dapat menurun karena tingkat kontaminasi bakteri pada platelet concentrates. Karena trombosit disimpan pada suhu 20 hingga $24^{\circ} \mathrm{C}$, bakteri yang masuk pada saat pengambilan lebih mungkin berkembang biak. Proses pengumpulan juga membahayakan volume gabungan trombosit yang meningkatkan kemungkinan bakteri masuk ke lingkungan pooled. Pooled trombosit masih dapat diberikan, namun produk pheresis trombosit dapat digunakan kapan saja jika memungkinkan.

Trombosit juga dapat dikumpulkan dengan hemaferesis. Trombosit harus menghasilkan trombosit minimal $3 \times 10^{11}$. Ini setara dengan lima hingga delapan unit trombosit yang dibuat dari darah utuh. Donor plateletpheresis dapat menyumbang dua kali seminggu hingga total 24 kali per tahun. Harus ada jeda waktu setidaknya 48 jam diantara donasi.

Trombosit yang diperoleh dengan pheresis dapat dicocokkan untuk HLA atau antigen trombosit lainnya pada penerima yang mungkin memiliki antibodi terhadap antigen spesifik pada permukaan trombosit. individu yang sering menerima transfusi trombosit dapat mengembangkan antibodi yang menurunkan kelangsungan hidup produk yang ditransfusikan. Pasien-pasien ini dikatakan refrakter terhadap trombosit yang ditransfusikan. Penting untuk menentukan antisipasi peningkatan jumlah trombosit pasca transfusi.

\section{Granulocyte Concentrate}


Konsentrat granulosit dibuat dengan hemaferesis. Komponen ini akan mengandung trombosit serta beberapa eritrosit. Konsentrat granulosit disimpan hingga 24 jam pada suhu 20 hingga 24 。 , tetapi memburuk dengan cepat saat disimpan. Setidaknya $75 \%$ dari unit yang diuji harus mengandung minimal $1,0 \times 10^{10}$ granulosit. Pencocokan silang diperlukan jika ada lebih dari $2 \mathrm{ml}$ eritrosit. Transfusi konsentrat granulosit harus dilakukan melalui filter yang tidak akan menghilangkan granulosit. Komponen harus disinari karena resipien seringkali merupakan individu dengan imunosupresi. Penggunaan konsentrat granulosit jarang terjadi karena potensi reaksi, penggunaan antibiotik yang lebih baik, dan perkembangan zat stimulasi sumsum tulang seperti faktor pertumbuhan rekombinan. Indikasi untuk transfusi granulosit meliputi: neutropenia $(<0,5 \times$ $\left.10^{9} / \mathrm{L}\right)$, infeksi, dan kurangnya respon terhadap antibiotik.

\subsection{PENYIMPANAN KOMPONEN DARAH}

Semua prosedur harus dilakukan oleh semua staf yang terlibat dengan penyimpanan komponen darah. Temperatur dan waktu penyimpanan berbagai komponen darah ada pada Tabel 4.3. Perawatan untuk penyimpanan komponen harus memenuhi kriteria, antara lain:

- Temperatur lemari es, freezer, inkubator trombosit, waterbath, dan suhu ruangan harus terjaga.

- Semua termometer yang dikalibrasi harus diperiksa terhadap termometer referensi.

- Suhu harus selalu terekam setiap empat jam.

Tabel 4.3 Kriteria Penyimpanan Berbagai Komponen Darah

\begin{tabular}{|c|c|c|}
\hline COMPONEMT & $\begin{array}{l}\text { STOAAGE } \\
\text { TEMPEAATUAE }\end{array}$ & STOAAOE TIME LIMITS \\
\hline \multirow[t]{2}{*}{ Whole Blood } & 1060 & CPO CP2O - 21 dips \\
\hline & & CPDA:1 - 35 dars \\
\hline \multirow[t]{2}{*}{ Ped Blood Cells } & $1 \mathrm{soc}$ & $\begin{array}{l}\text { CPO, CP2O - } 21 \mathrm{dms} \\
\text { CPDA-1 - 3S dirs }\end{array}$ \\
\hline & & AS-1, AS -3 , AS $-5=42$ days \\
\hline
\end{tabular}


(Whitlock, 2010)

\section{RANGKUMAN :}

- Teknologi pengolahan darah mampu menjadikan darah utuh (whole blood) dibagi menjadi beberapa bagian atau komponen.

- Fraksinasi whole blood menjadi beberapa komponen memungkinkan pasien untuk menerima terapi paling efektif dengan produk yang lebih aman daripada whole blood.

- Semua kantong darah memiliki bagian dalam yang steril, termasuk jarum dan semua tabung yang terpasang, dan mengandung larutan pengawet antikoagulan.

- Antikoagulan pada kantong darah akan mencegah darah menggumpal selama proses pengambilan darah. Antikoagulan utama yang digunakan adalah citrate-phosphate dextrose (CPD), citrate-phosphate-2-dextrose (CP2D), dan citrate-phosphatedextrose plus adenine (CPDA1). 
- Larutan aditif berfungsi untuk memperpanjang umur simpan eritrosit. Larutan aditif mengandung saline, adenin, dan dekstrosa atau meningkatkan pembentukan ATP, dan zat minor lainnya yang meningkatkan viabilitas eritrosit dalam kantong darah.

- Donor fraksinasi komponen darah dapat berupa: eritrosit, Red Blood Cells Leukocytes Reduced, Red Blood Cell Washed, Red Blood Cell Frozen, Fresh Frozen Plasma (FFP), Cryoprecipitated Antihemophilic Factor (CRYO), Platelet Concentrates (PC), Granulocyte Concentrate.

\section{LATIHAN SOAL :}


1. Berikut ini merupakan syarat kantong darah, kecuali
a. Berwarna
b. Transparan
c. Steril
d. Berisi antikoagulan
e. Berisi larutan aditif

2. Bagian dari antikoagulan yang dapat mengikat kalsium darah darah sehingga menghambat koagulasi, adalah
a. Fibrin
b. Natrium
c. Kalium
d. Sitrat
e. Saline

3. Penambahan larutan aditif pada kantong darah bertujuan untuk
a. Mencegah penggumpalan darah
b. Memperpanjang lama penyimpanan eritrosit
c. Mencegah adanya paparan udara
d. Jawaban A dan B benar
e. Jawaban A, B, dan C benar

4. Berikut ini merupakan metode pengolahan darah yang bertujuan ntuk mengurangi resiko timbulnya Human Leukocyte Antigen (HLA) atau granulocyte alloimmunization adalah
a. Red Blood Cell Washed
b. Red Blood Cell Frozen
c. Red Blood Cells Leukocytes Reduced
d. Fresh Frozen Plasma
e. Cryoprecipitated Antihemophilic Factor 
5. Metode pengolahan darah yang dilakukan bagi pasien defisiensi IgA ketika komponen seluler defisiensi IgA tidak tersedia, adalah
a. Red Blood Cell Washed
b. Red Blood Cell Frozen
c. Red Blood Cells Leukocytes Reduced
d. Fresh Frozen Plasma
e. Cryoprecipitated Antihemophilic Factor

6. Metode ini bertujuan untuk memperpanjang umur seluler dalam waktu lama melalui penghentian aktivitas biologis. Metode yang dimaksud adalah ..........
a. Red Blood Cell Washed
b. Red Blood Cell Frozen
c. Red Blood Cells Leukocytes Reduced
d. Fresh Frozen Plasma
e. Cryoprecipitated Antihemophilic Factor

7. Prosedur pengolahan darah yang diindikasikan untuk pasien defisiensi faktor koagulasi dengan tes koagulasi abnormal ditandai adanya perdarahan aktif adalah
a. Red Blood Cell Washed
b. Red Blood Cell Frozen
c. Red Blood Cells Leukocytes Reduced
d. Fresh Frozen Plasma
e. Cryoprecipitated Antihemophilic Factor

8. Metode yang awalnya dikembangkan sebagai terapi untuk pasien dengan defisiensi faktor antihemofilik, atau hemofilia $A$ adalah
a. Red Blood Cell Washed
b. Red Blood Cell Frozen
c. Red Blood Cells Leukocytes Reduced
d. Fresh Frozen Plasma 

e. Cryoprecipitated Antihemophilic Factor

9. Berikut ini merupakan kondisi yang memerlukan transfusi eritrosit, kecuali
a. Anemia akut
b. Anemia kronik
c. Thalasemia
d. HDFN
e. ITP

10. Sistem pengumpulan darah yang ideal adalah
a. Terbuka
b. Tertutup
c. Langsung
d. Tidak langsung
e. Bebas pengawet 
$=$ 


\section{REFERENSI :}

Khawar, H., Kelley, W., \& Guzman, N. (2020). Fresh Frozen Plasma. Treasure Island (FL): StatPearls Publishing. Retrieved from https://www.ncbi.nlm.nih.gov/books/NBK513347/

Nascimento, B., Goodnough, L. T, \& Levy, J. H. (2014). Cryoprecipitate therapy. British Journal of Anaesthesia, 113(6), 922-934. doi: 10.1093/bja/aeu158

Quinley, E. D. (2011). Immunohematology Principles \& Practice. Third Edition. Philadelphia: Lippincott Williams \& Wilkins.

Simon, C. D., Perkins, J., Barras, P., Eastridge, B., \& Blackbourne, L. H. (2009). Fresh Frozen Plasma. The Army Medical Department Journal, January-March 2009, 64-67. Retrieved from https://www.researchgate.net/publication/41090123_Fresh_fr ozen_plasma/link/559d57ac08aec72001826ff0/download

Suddock, J. T., \& Crookston, K. P. (2020). Transfusion Reactions. StatPearls Publishing LLC. Retrieved from https://www.ncbi.nlm.nih.gov/books/NBK482202/

Whitlock, S. A. (2010). Immunohematology For Medical Laboratory Technicians. USA: Delmar, Cengage Learning.

Fosmedic Medical Supplies-Shanghai Xingliao Trading Co.,Ltd. Retrieved from https://fosmedic68.en.ec21.com/. 


\section{BAB 5 \\ REAKSI TRANSFUSI DARAH}

\section{Sub - Capaian Pembelajaran Mata Kuliah :}

- Mampu memahami tentang penyebab terjadinya reaksi transfusi darah.

- Mampu memahami perbedaan reaksi transfusi akut dan tertunda.

- Mampu memahami berbagai jenis reaksi transfusi yang di mediasi oleh sistem imun dan non-imun.

\subsection{DEFINISI DAN PENYEBAB REAKSI TRANSFUSI}

Reaksi transfusi didefinisikan sebagai efek samping yang terkait dengan transfusi whole blood atau salah satu komponennya. Reaksi ini dapat terjadi dengan tingkat keparahan dari ringan sampai 
dengan mengancam jiwa. Reaksi dapat terjadi selama transfusi (acute transfusion reactions/ reaksi transfusi akut) atau beberapa hari hingga beberapa minggu kemudian (delayed transfusion reactions/ reaksi transfusi tertunda) dan dapat bersifat imunologis atau non-imunologis.

Reaksi mungkin sulit untuk didiagnosis karena dapat timbul dengan gejala yang tidak spesifik dan sering kali tumpang tindih. Tanda dan gejala yang paling umum termasuk demam, menggigil, urtikaria, dan gatal-gatal. Beberapa gejala hilang dengan sedikit atau tanpa pengobatan. Namun, gangguan pernapasan, demam tinggi, hipotensi, dan hemoglobinuria dapat menunjukkan reaksi yang lebih serius. Jenis reaksi transfusi meliputi: hemolitik akut (Hemolytic Transfusion Reactions/ HTRs), hemolitik tertunda, post transfusion purpura (PTP), demam non-hemolitik, anafilaksis, alergi sederhana, septic (kontaminasi bakteri), cedera paru akut terkait transfusi (Transfusion-Related Acute Lung Injury/ TRALI), dan kelebihan beban sirkulasi terkait transfusi (Transfusion-Associated Circulatory Overload/ TACO). Jika terjadi semua reaksi yang dicurigai maka harus segera menghentikan transfusi serta melaporkan bank darah dan dokter.

Reaksi transfusi terjadi dalam frekuensi dari yang relatif umum (alergi ringan dan reaksi non-hemolitik demam), hingga jarang (anafilaksis, hemolitik akut, dan sepsis). Efek samping fatal yang dilaporkan paling sering terjadi adalah TRALI. Sedangkan efek samping jangka panjang atau lambat biasanya merupakan hasil dari penularan penyakit. Tingkat keparahan dan kejadian bervariasi tergantung pada jenis reaksi transfusi, prevalensi penyakit pada pendonor, dan tingkat perawatan lanjutan yang diperoleh pasien. Karena kemajuan dalam sistem screening pendonor, pengujian yang lebih baik, dan sistem data otomatisasi, maka risiko dan kematian yang disebabkan oleh transfusi komponen darah terus menurun. 


\subsection{REAKSI TRANSFUSI AKUT}

Reaksi transfusi yang dimediasi imunitas (immune-mediated) umumnya terjadi karena mismactch (ketidakcocokan) atau inkompatibilitas produk transfusi terhadap resipien. Mereka termasuk antibodi yang terjadi secara alami dalam penerima darah (seperti anti-A, anti-B yang biasanya bertanggung jawab untuk reaksi transfusi hemolitik akut) serta antibodi yang dibuat sebagai respons terhadap antigen asing (alloantibodi). Aloantibodi ini menyebabkan banyak reaksi termasuk alergi ringan, demam non-hemolitik, hemolitik akut, dan anafilaksis. Antibodi yang ada dalam donor darah juga dapat menyebabkan reaksi dan dianggap terlibat dalam cedera paru terkait transfusi (TRALI).

Patofisiolog reaksi transfusi akut, antara lain:

- Alergi ringan: berkaitan dengan hipersensitivitas terhadap protein asing dalam produk donor.

- Anafilaksis: Mirip dengan reaksi alergi ringan, namun mengakibatkan reaksi yang lebih parah. Terkadang hal ini dapat terjadi pada pasien dengan defisiensi IgA yang membuat aloantibodi melawan IgA dan kemudian menerima produk darah yang mengandung $\lg A$.

- Demam non-hemolitik: Umumnya diduga disebabkan oleh sitokin yang dilepaskan dari leukosit donor darah.

- Septic: Disebabkan oleh bakteri atau produk sampingan bakteri (seperti endotoksin) yang dapat mencemari darah.

- Hemolytic Transfusion Reactions (Reaksi transfusi hemolitik akut/ HTRs): Dapat menyebabkan hemolisis intravaskular atau ekstravaskular, tergantung pada etiologi spesifik (penyebabnya). Reaksi yang dimediasi oleh kekebalan seringkali merupakan hasil dari antibodi penerima yang ada pada antigen donor darah. Reaksi non-imun mungkin terjadi, dan terjadi ketika eritrosit rusak 
sebelum transfusi (misalnya, oleh panas atau kondisi osmotik yang salah).

- Transfusion-associated circulatory overload (TACO): Terjadi ketika volume komponen yang ditransfusikan menyebabkan hipervolemia (kelebihan volume).

- Transfusion-related acute lung injury (TRALI): Cedera paru akut disebabkan oleh antibodi dalam produk donor (antigen leukosit manusia atau antigen neutrofil manusia) yang bereaksi dengan antigen pada resipien. Sistem kekebalan penerima merespons dan menyebabkan pelepasan mediator yang menyebabkan edema paru. Kemungkinan penyebabnya adalah kondisi klinis yang mempengaruhi pasien, termasuk infeksi, pasca pembedahan, atau inflamasi.

\subsection{REAKSI TRANSFUSI TERTUNDA}

Reaksi non-imunologis biasanya disebabkan oleh efek fisik komponen darah atau penularan penyakit. Kontaminasi bakteri, misalnya, mengakibatkan reaksi transfusi septic dan disebabkan oleh kontaminasi bakteri dan / atau endotoksin pada produk darah. Hal ini dapat terjadi pada saat pengambilan darah karena desinfeksi lengan donor darah yang tidak tepat, adanya bakteri dalam sirkulasi donor pada saat pengambilan, atau karena penanganan produk yang tidak tepat setelah pengambilan. Reaksi transfusi juga dapat terjadi tidak terkait dengan faktor intrinsik darah. Contohnya termasuk kelebihan volume terkait transfusi (TACO) dan hipotermia.

Patofisiolog reaksi transfusi tertunda, antara lain:

- Reaksi transfusi hemolitik yang tertunda: Biasanya disebabkan oleh respons anamnestik terhadap antigen asing yang sebelumnya terpajan pada pasien (umumnya dengan transfusi sebelumnya atau kehamilan).

- Transfusion-associated graft-versus-host disease (TA-GVHD): Hasil dari pengikatan limfosit donor (biasanya ditemukan dalam 
produk darah seluler) ke dalam sumsum tulang penerima yang immunocompromised. Limfosit donor mengenali pasien sebagai benda asing dan bereaksi terhadap tubuh resipien. Sistem kekebalan pasien tidak dapat membersihkan limfosit asing. Ini jarang terjadi tetapi seringkali berakibat fatal.

\section{A. Immediate HemolyticTransfusion Reactions (IHTR)}

Reaksi transfusi hemolitik segera yang terjadi setelah transfusi eritrosit yang tidak kompatibel. Eritrosit yang ditransfusikan dengan cepat dihancurkan dengan pelepasan hemoglobin dan stroma dari sel hemolisis ke dalam sirkulasi. Penyebab hemolisis biasanya karena adanya alloantibodi yang terbentuk sebelumnya yang diproduksi sebagai hasil dari transfusi atau kehamilan sebelumnya. Umumnya ini disebabkan oleh antibodi ABO yang terjadi secara alami. Ketika eritrosit yang tidak kompatibel ditransfusikan, kompleks antigenantibodi terbentuk, yang mengaktifkan sistem komplemen, plasminogen, kinin, dan koagulasi. Hanya sejumlah kecil darah yang tidak sesuai yang perlu ditransfusikan untuk memicu tanda dan gejala IHTR yang akan datang. Tanda dan gejala pertama mungkin termasuk demam, menggigil, ketidaknyamanan umum, sakit punggung, hemoglobinuria, dispnea, hipotensi, syok, pendarahan yang tidak terkendali, nyeri di tempat infus, mual, kemerahan, pusing, nyeri substernal, hemoglobinemia, dan anemia.

\section{B. Delayed Hemolytic Transfusion Reaction (DHTR)}

Reaksi transfusi hemolitik yang tertunda (DHTR) adalah penghancuran darah yang ditransfusi atau komponen darah setelah suatu interval di mana penerima meningkatkan respons imun sekunder terhadap antigen asing. Reaksi ini mungkin terlihat bersamaan dengan reaksi transfusi serologi yang tertunda (DSTR) di mana eritrosit yang menyebar menjadi peka oleh antibodi yang baru 
terbentuk tanpa hemolisis klinis. Berbagai alloantibodi telah terlibat sebagai penyebab DHTR.

\section{Febrile Non-HemolyticTransfusion Reactions (FNHTRs)}

Reaksi transfusi non-hemolitik demam (FNHTRs) adalah efek samping yang umum terjadi setelah transfusi darah dan komponen darah. Sebagian besar reaksinya ringan, namun dapat pula mengancam nyawa karena kemungkinan syok anafilaksis yang parah. Reaksi ini terjadi pada sekitar 0,5\% dari darah non-leukosit yang direduksi darah dan transfusi komponen darah, dan pasien dengan riwayat FNHTR memiliki sekitar $15 \%$ risiko mengalami keadaan ini lagi. AFNHTR terjadi pada sekitar 3\% hingga $7 \%$ pasien yang menerima transfusi eritrosit dan pada $20 \%$ hingga $30 \%$ pasien yang menerima konsentrat trombosit (PC). Reaksi ini adalah jenis reaksi transfusi yang paling umum dan dipicu oleh adanya leukoagglutinin muncul di plasma resipien. Aloimunisasi biasanya akibat pajanan antigen melalui transfusi sebelumnya, transplantasi jaringan, atau kehamilan.

Tabel 5.1 Jenis Reaksi Transfusi yang Dimediasi oleh Imun dan Non-Imun

\begin{tabular}{|c|c|c|c|}
\hline \multicolumn{2}{|c|}{ Immune Mediated Transfusion Reactions } & \multicolumn{2}{|c|}{$\begin{array}{c}\text { Non Immune Mediated Transfusion } \\
\text { Reactions }\end{array}$} \\
\hline $\begin{array}{l}\text { Immediate } \\
\text { Reactions }\end{array}$ & Delayed Reactions & $\begin{array}{l}\text { Immediate } \\
\text { Reactions }\end{array}$ & $\begin{array}{l}\text { Delayed } \\
\text { Reactions }\end{array}$ \\
\hline $\begin{array}{l}\text { Immediate } \\
\text { hemolytic } \\
\text { transfusion } \\
\text { reaction (IHTR) }\end{array}$ & $\begin{array}{l}\text { Delayed hemolytic } \\
\text { transfusion reaction } \\
\text { (DHTR) }\end{array}$ & $\begin{array}{l}\text { - Transfusion related } \\
\text { bacteria } \\
\text { contamination } \\
\text { (TRBC) }\end{array}$ & $\begin{array}{l}\text { - Viral } \\
\text { Contamination }\end{array}$ \\
\hline $\begin{array}{l}\text { Febrile non } \\
\text { hemolytic } \\
\text { transfusion } \\
\text { reaction (FNTR) }\end{array}$ & $\begin{array}{l}\text { - Delayed serological } \\
\text { transfusion reaction } \\
\text { (DSTR) }\end{array}$ & - Circulatory overload & - Iron Overload \\
\hline
\end{tabular}




\begin{tabular}{lll}
\hline $\begin{array}{l}\text { - Anaphylactic and } \\
\text { anaphylactoid } \\
\text { reactions }\end{array}$ & $\begin{array}{l}\text { - Post transfusion } \\
\text { purpura (PTP) }\end{array}$ & $\begin{array}{l}\text { - Physically \& } \\
\text { chemically induced } \\
\text { transfusion } \\
\text { reactions }\end{array}$ \\
- Allergic reactions & $\begin{array}{l}\text { - Transfusion- } \\
\text { associated graft- } \\
\text { versus-host disease } \\
\text { (TA-GVHD) }\end{array}$ & \\
$\begin{array}{l}\text { - Alloimmunization } \\
\text { pulmonary } \\
\text { reactions (TRALI) }\end{array}$ & \\
\hline
\end{tabular}

(Ogedegbe, 2020)

\section{Allergic Transfusion Reactions}

Reaksi akut terhadap konstituen plasma dapat diklasifikasikan sebagai alergi, anafilaktoid, atau anafilaksis. Reaksi alergi terhadap komponen yang tidak diketahui dalam darah donor sering terjadi, biasanya karena alergen dalam plasma donor atau, lebih jarang, antibodi dari donor alergi. Antibodi IgE menempel pada sel mast dan basofil, yang menyebabkan pelepasan histamin dan vasoaktif amina. Reaksi biasanya ringan dengan urtikaria, edema, pusing sesekali, dan sakit kepala selama atau segera setelah transfusi. Lebih jarang, dispnea, mengi (nafas bunyi), dan inkontinensia dapat terjadi, yang menunjukkan kejang otot polos secara umum. Jarang dapat terjadi anafilaksis.Pada pasien dengan riwayat alergi atau reaksi alergi transfusi, antihistamin dapat diberikan secara profilaksis sebelum atau pada awal transfusi. Obat tidak boleh dicampur dengan darah. Jika terjadi reaksi alergi, transfusi dihentikan dan antihistamin diberikan untuk mengendalikan kasus ringan. Untuk reaksi yang lebih parah, epinefrin harus diberikan. Kortikosteroid terkadang 
diperlukan, dan investigasi reaksi transfusi dimulai. Transfusi lebih lanjut sebaiknya tidak dilakukan sampai pemeriksaan selesai. Pada reaksi yang parah, harus diberikan deglycerolized frozen red blood cells.

\section{E. Anaphylactic Transfusion Reaction}

Reaksi anafilaksis merupakan kejadian yang langka, yang terjadi pada pasien yang kekurangan IgA dan telah mengembangkan antibodi anti-IgA. Produksi antibodi IgA dapat mengikuti imunisasi dari transfusi atau kehamilan sebelumnya, dan beberapa pasien mungkin memiliki antibodi tanpa paparan yang diketahui sebelumnya. Defisiensi IgA merupakan yang paling umum dari semua defisiensi selektif imunoglobulin serum. Reaksi transfusi anafilaksis IgA diperkirakan terjadi pada 1 dari 20.000 hingga 47.000 transfusi darah. Tanda dan gejala reaksi ini dramatis dan cepat pada awalnya dan muncul tiba-tiba setelah terpapar protein IgA seringkali sebelum $10 \mathrm{~mL}$ plasma diinfuskan. Gejala mungkin termasuk mual, kram perut, muntah, dan diare. Hipertensi transien dapat diikuti oleh hipotensi, syok, dan kehilangan kesadaran. Tidak adanya demam membedakan reaksi anafilaksis dari reaksi langsung lainnya.

\section{F. Noncardiogenic Pulmonary Reaction}

Reaksi paru nonkardiogenik juga dikenal sebagai cedera paru akut terkait transfusi (TRALI) adalah komplikasi terapi transfusi yang jarang tetapi mengancam jiwa. Secara klinis mirip dengan sindrom gangguan pernapasan dewasa (adult respiratory distress syndrome/ ARDS) tetapi dengan prognosis yang jauh lebih baik. Tingkat kematian yang telah dilaporkan sebanyak $5 \%$ sampai $10 \%$, sedangkan ARDS mencapai 50\% sampai 60\%. Reaksi biasanya dimulai dalam 6 jam setelah peristiwa transfusi dan ditandai dengan edema paru yang parah, hipoksemia berat, hipotensi, menggigil, dan demam. 
Kardiogenik dan penyebab lain dari gangguan pernapasan harus disingkirkan. Dalam kebanyakan kasus, TRALI membaik secara klinis dalam 48 hingga 96 jam setelah onset. Kadang-kadang muncul sebagai komplikasi transfusi yang tidak diketahui. Hal ini dapat menyebabkan kesalahan diagnosis akibat kelebihan beban sirkulasi, dan menghasilkan terapi yang tidak tepat. Ini telah dikaitkan dengan berbagai jenis transfusi komponen darah seperti wholeblood, eritrosit, platelet concentrates (PC), dan granulosit, tetapi tidak dengan turunan plasma. Produk imunoglobulin untuk penggunaan intravena belum pernah dilaporkan menyebabkan TRALI. Antibodi granulosit dan/ atau HLA, yang terdapat dalam darah donor, paling sering dianggap sebagai penyebab TRALI. Alloimunisasi terhadap antigen granulosit terlihat pada sekitar $3 \%$ wanita hamil, pada 7,7\% donor wanita, dan hingga $78 \%$ penerima transfusi granulosit.

\section{G. Transfusion-Associated Graft-Versus-Host Disease (TA-GVHD)}

Pasien yang mengalami imunosupresi berat, seperti pasien yang menjalani kemoterapi antikanker intensif, berisiko mengalami engraftment (peningkatan leukosit) dan GVHD yang tidak disengaja ketika mereka menjalani transfusi dengan komponen darah seluler, suatu kondisi yang dikenal sebagai TA-GVHD. Untuk mencegah komplikasi ini, komponen darah harus diradiasi sebelum transfusi, meskipun dosis iradiasi minimum yang diperlukan tidak pasti. Penyakit graft-versus-host biasanya disebabkan oleh pencangkokan limfosit imunokompeten dari transplantasi sumsum tulang ke pasien yang mengalami gangguan sistem imun. Namun, bahkan sejumlah kecil limfosit dalam darah atau transfusi komponen darah dapat membelah secara spontan dan menyebabkan GVHD pada penerima imunosupresi. Pencegahan adalah dengan penyinaran semua produk darah yang ditujukan untuk transfusi ke pasien tersebut. 


\section{H. Alloimmunization}

Refraktori trombosit yang meningkat dari alloimunisasi HLA merupakan komplikasi serius dari terapi transfusi. Walaupun transfusi efektif dalam mencegah morbiditas sel sabit, penggunaannya dipersulit oleh tingginya insiden aloimunisasi eritrosit dan komplikasi terkait transfusi. Risiko aloimunisasi terus meningkat dengan pajanan eritrosit, sehingga $60 \%$ orang dewasa yang ditransfusikan secara kronis menjadi aloimunisasi. Lebih lanjut, lebih dari separuh pasien ini memiliki antibodi terhadap lebih dari 1 antigen, yang membuatnya sulit untuk mendapatkan darah yang kompatibel, dan mengakibatkan DHTR dan kejadian yang terkadang mengancam nyawa. Data awal menunjukkan bahwa aloimunisasi juga meningkatkan laju pembentukan autoantibodi eritrosit pada penyakit sel sabit (SCD). Mekanisme yang mendasari peningkatan kejadian aloimunisasi pada pasien ini mungkin multifaktorial, tetapi kurangnya kompatibilitas fenotipik antara darah donor dan resipien jelas merupakan faktor utama.

\section{Immunosuppression}

Transfusi darah dapat menekan sistem imun resipien dan menghasilkan risiko transfusi yang disebut imunomodulasi. Risiko ini tampaknya sangat terkait dengan adanya leukosit donor dalam produk yang ditransfusikan. Imunosupresi dapat menyebabkan kejadian yang mengancam jiwa, seperti kegagalan multi organ, peningkatan risiko infeksi setelah operasi, dan/ atau berkurangnya kemungkinan penyembuhan pada pasien dengan keganasan tertentu. Efek lain dari imunosupresi termasuk penurunan tingkat penolakan allograft (cangkok jaringan yang asal jaringannya diambil dari individu satu ke individu lain yang berbeda konstitusi genetikanya tetapi dalam satu spesies), penurunan kejadian aborsi spontan berulang, dan penurunan angka kekambuhan penyakit 
Crohn. Imunosupresi terkait transfusi dapat menyebabkan peningkatan insiden infeksi pada pasien yang ditransfusikan pasca trauma dan pembedahan. Studi klinis telah menunjukkan bahwa pengurangan leukosit dengan filtrasi komponen darah dapat mengurangi transfusi terkait imunosupresi dan menurunkan tingkat infeksi pasca operasi. Donor darah autologus pra operasi biasanya digunakan untuk mengurangi pajanan terhadap transfusi alogenik di antara pasien yang menjalani operasi elektif, dengan tujuan membatasi terjadinya penularan infeksi virus melalui komponen darah dan mengurangi risiko aloimunisasi dan imunosupresi.

\section{J. Post Transfusion Purpura (PTP)}

Purpura pasca transfusi merupakan komplikasi transfusi yang jarang terjadi dan menyebabkan trombositopenia secara mendadak yang berkembang 5 hingga 10 hari setelah transfusi whole blood, RBC, FFP, atau PCs. Pasien yang mengalami komplikasi ini telah mengembangkan antibodi anti-platelet pada masa kehamilan atau transfusi sebelumnya. Transfusi selanjutnya memicu penghancuran yang dimediasi imunitas trombosit pasien sendiri yang mengakibatkan trombositopenia yang parah di mana tingkat trombosit sering turun menjadi $<10.000 / \mu \mathrm{l}$. Purpura pasca transfusi bermanifestasi pada orang dewasa, terutama wanita, dengan perdarahan selaput lendir, epistaksis, perdarahan gastrointestinal, dan perdarahan dari saluran kemih. Sembilan persen pasien mengalami perdarahan intra kranial. Pemulihan platelet spontan terjadi dalam 2 minggu. Untuk sementara, pasien dapat diobati dengan kortikosteroid, pertukaran plasma, imunoglobulin intravena dosis tinggi, dan transfusi dengan $\mathrm{P} 1^{\mathrm{A} 1}$ negative platelets. 


\section{RANGKUMAN :}

- Reaksi transfusi dapat terjadi selama transfusi (acute transfusion reactions/ reaksi transfusi akut) atau beberapa hari hingga beberapa minggu kemudian (delayed transfusion reactions/ reaksi transfusi tertunda) dan dapat bersifat imunologis atau nonimunologis.

- Reaksi transfusi terjadi dalam frekuensi dari yang relatif umum (alergi ringan dan reaksi non-hemolitik demam), hingga jarang (anafilaksis, hemolitik akut, dan sepsis). Efek samping fatal yang dilaporkan paling sering terjadi adalah TRALI. Sedangkan efek samping jangka panjang atau lambat biasanya merupakan hasil dari penularan penyakit.

- Jenis reaksi transfusi meliputi: hemolitik akut (Hemolytic Transfusion Reactions/ HTRs), hemolitik tertunda, post transfusion purpura (PTP), demam non-hemolitik, anafilaksis, alergi sederhana, septic (kontaminasi bakteri), cedera paru akut terkait transfusi (Transfusion-Related Acute Lung Injury/ TRALI), dan kelebihan beban sirkulasi terkait transfusi (TransfusionAssociated Circulatory Overload/ TACO). 
LATIHAN SOAL : 
1. Reaksi dapat terjadi selama transfusi dinamakan ...........
a. Reaksi transfusi akut
b. Reaksi transfusi kronik
c. Reaksi transfusi tertunda
d. Jwaban A dan B benar
e. Jawaban A, B, dan C benar

2. Berikut ini merupakan penyakit yang disebabkan oleh bakteri atau produk sampingan bakteri yang dapat mencemari darah, adalah
a. Demam non hemolitik
b. Anafilaksis
c. TRALI
d. Urtikaria
e. Septic

3. Adanya cedera paru akut oleh antibodi dalam produk donor yang bereaksi dengan antigen pada resipien dinamakan ...........
a. Demam non hemolitik
b. Anafilaksis
c. TRALI
d. Urtikaria
e. Septic

4. Reaksi transfusi hemolitik segera yang terjadi setelah transfusi eritrosit yang tidak kompatibel disebut ..........
a. IHTR
b. DHTR
c. FNHTR
d. TA-GVHD
e. PTP

5. Komplikasi transfusi yang menyebabkan trombositopenia secara mendadak yang pada 5 hingga 10 hari setelah transfusi darah adalah 

a. IHTR
b. DHTR
c. FNHTR
d. TA-GVHD
e. PTP

6. Penyakit karena adanya pencangkokan limfosit imunokompeten dari transplantasi sumsum tulang ke pasien yang mengalami gangguan sistem imun ialah ..........
a. IHTR
b. DHTR
c. FNHTR
d. TA-GVHD
e. PTP

7. Jenis reaksi transfusi yang paling umum dan dipicu oleh adanya leukoagglutinin pada plasma resipien, disebut ..........
a. IHTR
b. DHTR
c. FNHTR
d. TA-GVHD
a. PTP

8. Kegagalan multi organ, peningkatan risiko infeksi setelah operasi, dan berkurangnya kemungkinan penyembuhan pada pasien dengan keganasan tertentu. Hal ini merupakan kejadian yang disebabkan oleh ...........
a. Allergic Transfusion Reactions
b. Anaphylactic Transfusion Reaction
c. Alloimmunization
d. Immunosuppression
e. Noncardiogenic Pulmonary Reaction 
9. Kejadian langka yang terjadi pada pasien kekurangan IgA dan telah mengembangkan antibodi anti-IgA dapat menyebabkan
a. Allergic Transfusion Reactions
b. Anaphylactic Transfusion Reaction
c. Alloimmunization
d. Immunosuppression
e. Noncardiogenic Pulmonary Reaction

10.Reaksi transfusi yang terjadi ketika volume komponen yang ditransfusikan menyebabkan hipervolemia (kelebihan volume), disebut
a. TACO
b. Anafilaksis
c. TRALI
d. Urtikaria
e. Septic 


\section{REFERENSI :}

Ogedegbe, H. O. (2020). A Review of Immune Mediated Transfusion Reaction. Laboratory Medicine, 4(33), 287-295. Retrieved from https://academic.oup.com/labmed/article/33/4/287/2657227

Quinley, E. D. (2011). Immunohematology Principles \& Practice. Third Edition. Philadelphia: Lippincott Williams \& Wilkins.

Suddock, J. T., \& Crookston, K. P. (2020). Transfusion Reactions. StatPearls Publishing LLC. Retrieved from https://www.ncbi.nlm.nih.gov/books/NBK482202/

Whitlock, S. A. (2010). Immunohematology For Medical Laboratory Technicians. USA: Delmar, Cengage Learning. 


\section{DAFTAR PUSTAKA}

Anastasiadi, A. T., Tzounakas, V. L., Kriebardis, A. G., Stamoulis, K. E., Seghatchian, J., \& Antonelou, M. H. (2020). When I need you most: frozen red blood cells for transfusion. Transfusion and Apheresis Science, Vol. 59, 1-4. https://doi.org/10.1016/j.transci.2020.102786.

Baratawidjaja, K., \& Rengganis, I. (2018). Imunologi Dasar. Edisi ke 12. Jakarta: FKUI.

Daniels, G., \& Bromilow, I. (2014). Essential Guide to Blood Groups. Third Edition. West Sussex, UK: Wiley Blackwell.

Dean, L. (2005). Blood Groups and Red Cell Antigens. Bethesda (MD): National Center for Biotechnology Information (US).

Fosmedic Medical Supplies-Shanghai Xingliao Trading Co.,Ltd. Retrieved from https://fosmedic68.en.ec21.com/.

Khawar, H., Kelley, W., \& Guzman, N. (2020). Fresh Frozen Plasma. Treasure Island (FL): StatPearls Publishing. Retrieved from https://www.ncbi.nlm.nih.gov/books/NBK513347/

Kim, K. H., \& Oh, K. Y. (2016). Clinical applications of therapeutic phlebotomy. Journal of Blood Medicine, Vol. 7, 139-144. doi: 10.2147/JBM.S108479.

Kumagai, I., \& Tsumoto, K. (2014). Antigen-Antibody Binding. Encyclopedia of Life Sciences, 1-7. https://doi.org/10.1002/9780470015902.a0001117.pub2

Kresno, S. B. (2010). Imunologi: Diagnosis dan Prosedur Laboratorium. Edisi Kelima. Jakarta: Balai Penerbit FKUI 
Maharani, E. A., \& Noviar, G. (2018). Imunohematologi dan Bank Darah. Jakarta: Pusat Pendidikan Sumber Daya Manusia Kesehatan Kemenkes RI.

Mitra, R., Mishra, N., \& Rath, G. P. (2014). Blood groups systems. Indian journal of anaesthesia, 58(5), 524-528. https://doi.org/10.4103/0019-5049.144645

Mekanisme Fagositosis.

Retrieved from https://brainly.co.id/tugas/438737.

Motghare, P., Kale, L., Bedia, A. S., \&Charde, S. (2011). Efficacy and Accuracy of ABO Blood Group Determination from Saliva. Journal of Indian Academy of Oral Medicine and Radiology,23(3), 163-167. Retrieved from https://pdfs.semanticscholar.org/8600/7ad158b254744506916a9a9 c66fe3991b334.pdf.

Nascimento, B., Goodnough, L. T, \& Levy, J. H. (2014). Cryoprecipitate therapy. British Journal of Anaesthesia, 113(6), 922-934. doi: 10.1093/bja/aeu158

Ogedegbe, H. O. (2020). A Review of Immune Mediated Transfusion Reaction. Laboratory Medicine, 4(33), 287-295. Retrieved from https://academic.oup.com/labmed/article/33/4/287/2657227

Olson, K. R., \& Nardin, E. D. (2016). Imunologi dan Serologi Klinis Modern. Jakarta: EGC.

Playfair, J. H. L., \& Chain, B .M. (2012). At a Glance Imunologi. Edisi Kesembilan. Jakarta: Erlangga.

Quinley, E. D. (2011). Immunohematology Principles \& Practice. Third Edition. Philadelphia: Lippincott Williams \& Wilkins. 
Rantam, F. A. (2003). Metode Imunologi. Surabaya: Airlangga University Press.

Simon, C. D., Perkins, J., Barras, P., Eastridge, B., \& Blackbourne, L. H. (2009). Fresh Frozen Plasma. The Army Medical Department Journal, January-March 2009, 64-67. Retrieved from https://www.researchgate.net/publication/41090123_Fresh_frozen _plasma/link/559d57ac08aec72001826ffo/download

Smart, E., \& Armstrong, B. (2008). Blood Group System. Journal compilation Science Series, 3, 68-92. https://doi.org/10.1111/j.1751-2824.2008.00188.x

Spectra Optia Apheresis System. Retrieved from https://www.terumobct.com/spectra-optia.

Stanford Blood Center. (2016). Directed Blood Donation Information. Palo Alto California. Retrieved from https://stanfordbloodcenter.org/wp-content/uploads/2017/06/03F09Form_DirectedDonationInfoSheet.pdf

Suddock, J. T., \& Crookston, K. P. (2020). Transfusion Reactions. StatPearls Publishing LLC. Retrieved from https://www.ncbi.nlm.nih.gov/books/NBK482202/

United Health Care. (2018). Apheresis. Britain: Oxford Health Plans. Retrieved from https://www.oxhp.com/secure/policy/apheresis.pdf

Whitlock, S. A. (2010). Immunohematology For Medical Laboratory Technicians. USA: Delmar, Cengage Learning.

World Health Organization (WHO). (2009). Safe Blood and Blood Products, Module 3, Blood Group Serology. USA: WHO Press. 
Zhou, J. (2016). A Review of the Application of Autologous Blood Transfusion. Brazilian Journal of Medical and Biological Research, 49(9), 1-6. doi: 10.1590/1414-431X20165493. 


\section{BIODATA PENULIS}

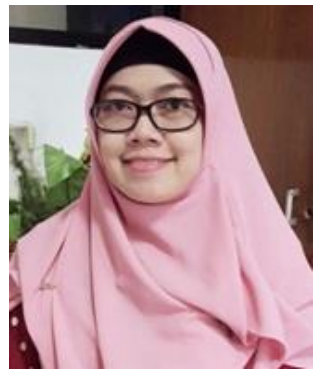

Andika Aliviameita, S.ST., M.Si. dilahirkan di Bangkalan, 30 Mei 1987. Pada tahun 2008, penulis mendapatkan gelar Ahli Madya Analis Kesehatan, kemudian pada tahun 2009 penulis memperoleh gelar Sarjana Sains Terapan dari jurusan Analis Kesehatan Poltekkes Depkes Surabaya. Penulis melanjutkan Magister IImu Forensik dari Universitas Airlangga Surabaya. Tahun 2018, penulis secara resmi mendapatkan gelar M.Si. Penulis mengawali karirnya sebagai Dosen di Program Studi Teknologi Laboratorium Medis Fakultas Ilmu Kesehatan Universitas Muhammdiyah Sidoarjo.

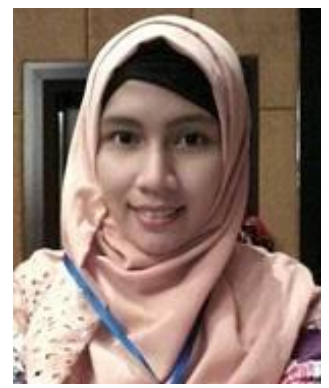

Puspitasari, S.ST., MPH lahir di Sidoarjo, 9 November 1990. Lulus sebagai Ahli Madya Analis Kesehatan tahun 2011, dan memperoleh gelar Sarjana Sains Terapan dari jurusan Analis Kesehatan Poltekkes Kemenkes Surabaya tahun 2012. Penulis melanjutkan studi S2 di Prodi Ilmu Kesehatan Masyarakat Universitas Sebelas Maret Surakarta (UNS) Iulus tahun 2017. Karir pendidikan dimulai tahun 2013 di Program Studi Teknologi Laboratorium Medis Fakultas Ilmu Kesehatan Universitas Muhammdiyah Sidoarjo. 